To: Distribution

From: D. E. Legare

Date: $12-12-94$

Project Title/Work Order:

Project W-151, W-320

DZDE3

ECN No.: 617567

EDT No.: $N / A$

Neme

MSIM

With Full
Size
Attachment

With Half
size

Attachment

Charge Code:

Q2013

U.S. Department of Energy

J. J. Davis

A. G. Lassila

S6-62

R3-73

E. W. Leschbar

G3-20

Westinghouse Hanford Company

J. R. Biggs

R. E. Clayton

D. W. Crass

R. A. Dodd

J. L. Dowe 11

R. W. Eggers

J. L. Eliason

F. R. Fisher

T. E. Griffin

J. P. Harris

J. J. Huston

C. M. Keller

J. S. Lee

D. E. Legare

M. E. Manthei

R. M. Nelson

E. M. Nordquist (2)

T4-01

R3-27

H5-68

55-05

L7-05

N1-84

K9-45

H5-70

L6-13

S6-12

S6-12

$\mathrm{H} 5-70$

57-03

H5-68

R3-27

R3-09

R. E. Russell

R3-27

T. N. Shaw

H5-70

R. N. Sherman

S6-12

R3-08

J. E. Van Beek

L4-74

IPF \#1

Central Files

Project Files

$28-04(2)$

OSTI (2)

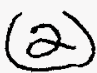

R3-27

18-04

$\mathrm{R} 1-28$

L8-07

$x$
$x$
$x$
$x$
$x$
$x$
$x$
$x$
$x$
$x$
$x$
$x$
$x$
$x$
$x$
$x$
$(2)$
$x$
$x$
$x$
$x$
$x$
$x$
$x(2)$




\section{DISCLAIMER}

Portions of this document may be illegible in electronic image products. Images are produced from the best available original document. 


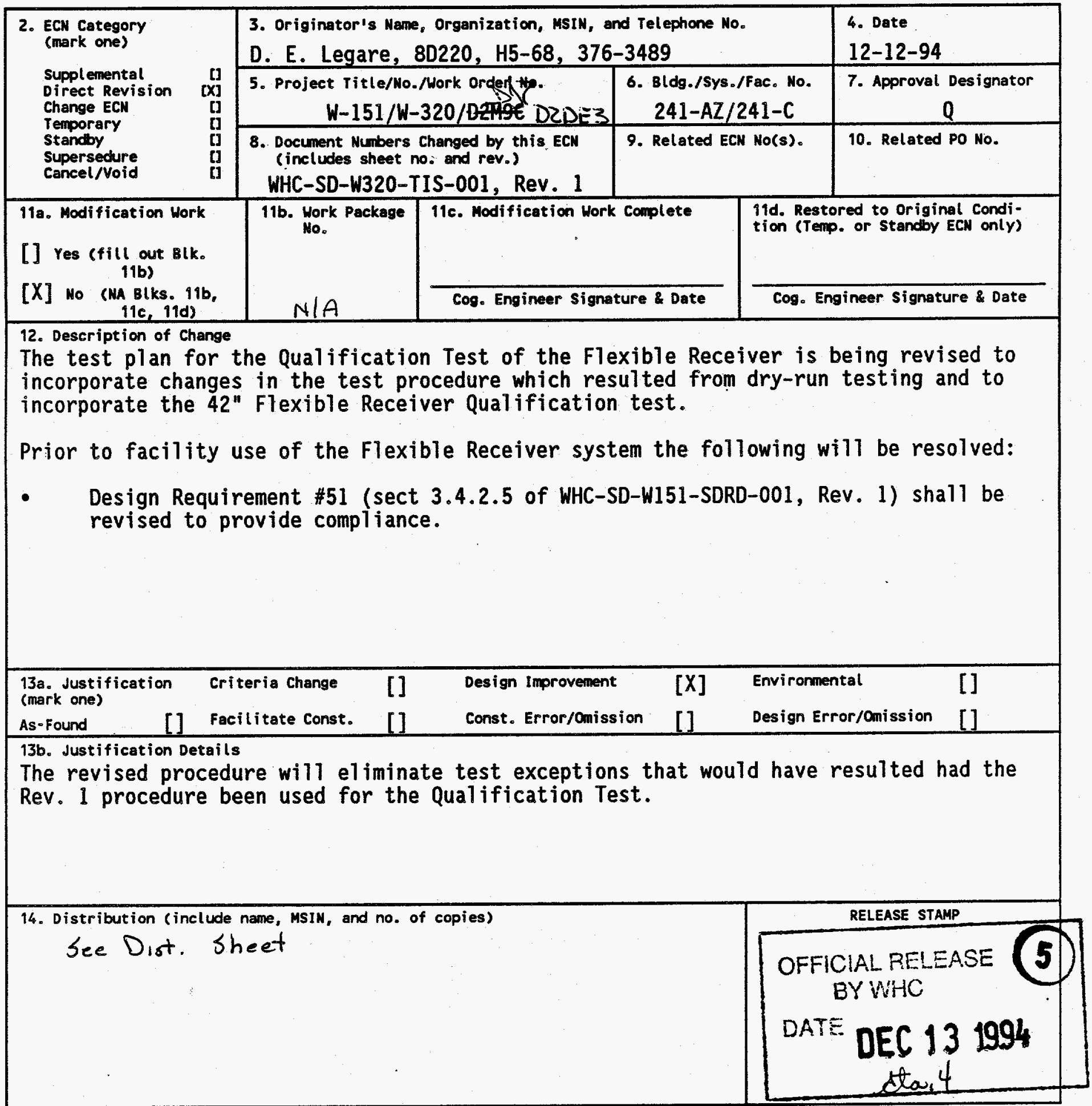


16. Cost Impact

Verification

Required

[] res

[X] No

617567

18. Change Impact Review: Indicate the related documents (other than the engineering documents identified on side 1) that will be affected by the change described in Block 12 . Enter the affected document number in Block 19. SDD/DD

Functional Design Criteria

Operating Specifleation

Criticality Specification

Concoptual Dosion Roport

Equipment Spec.

Conet. Spec.

Procurement Spec.

Vendor Information

OM Manuad

FSARISAR

Safoty Equipment List

Radiation Work Permit

Environmental impact Statement

[] Seismic/Stress Analysis

[]

[]

[]

[]

[]

[]

[]

[]

[]

[]

[]

[]

[]

[]
Stress/Design Repert

Interface Control Drawing

Calibration Procedure

installation Procedure

Maintenance Procedure

Engineering Procedure

Operating Instruction

Operating Procodure

Operational Safiaty Requirement

IEFD Drewing

Call Arrangement Drawing

Escontisl Material Specification

Fac. Proc. Samp. Schodule

Inspection Plan

Invontory Adjustment Roquest
[]

[]

[]

[]

[]

[]

[]

[]

[]

[]

[]

[]

[]

[]

[]

17. Schedule Impact (days)

Improvement

[] $\mathrm{N} / \mathrm{A}$

Delay

[]

Tank Calibration Manual

Hoalth Physics Proceduro

Spares Multiple Unit Lieting

Test Procodures/Specification

Component Index

ASME Coded kem

Human Facter Conaideration

Computer Software

Eloctric Circuit Schedule

ICAS Procedure

Procese Control Manual/Plan

Process Flow Chart

Purchese Requisition

Tickler File

19. Other Affected Documents: (NOTE: Documents listed below will not be revised by this ECN.) Signatures below indicate that the signing organization has been notified of other affected documents listed below. Document Number/Revision Document Number/Revision Document Number Revision N/A

20. Approvals

Signature OPERATIONS AND ENGINEERING

Cog. Eng. OE Legare $O$ \% 2 acee cog. Mgr。 RK Brown/CER anset/a

OA RE Clayton

Safety

Environ.

other

Projects TN Shaw $T . A 1$

Projects/Programs EM Nordquist

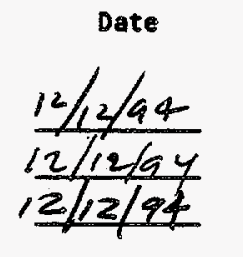

Signature

Date
PE

QA

Safety

Design

Environ.

other

\section{DEPARTMENT OF ENERGY}

Signature or a Control Number that tracks the Approval signature

ADDITIONAL 


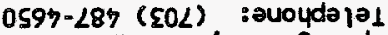

lolzz Vn 'platj6utJds

peoy jekoy ajod 5825

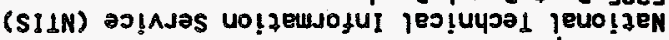

asdaunos to juewzjedea is $S^{\circ} \mathrm{n}$

$1078-925$ (SL9) :auoydajol

IERLE NL "әEp!Y YBO

$29 \times 08{ }^{\circ} 0^{\circ} \mathrm{d}$

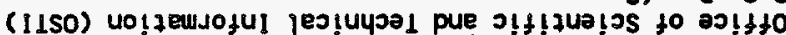

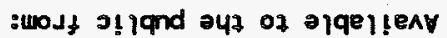

:40d\&

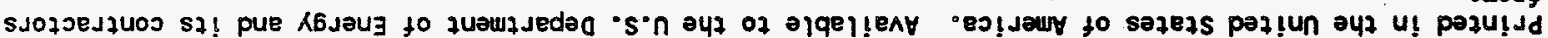

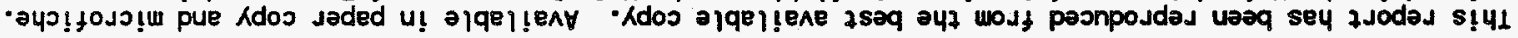

- sjozosjzuoxgns

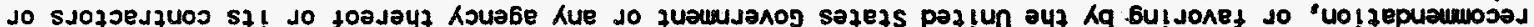

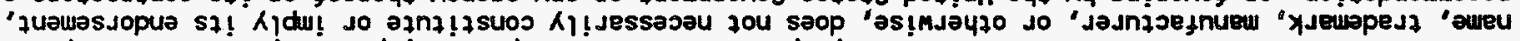

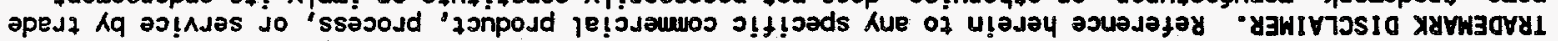

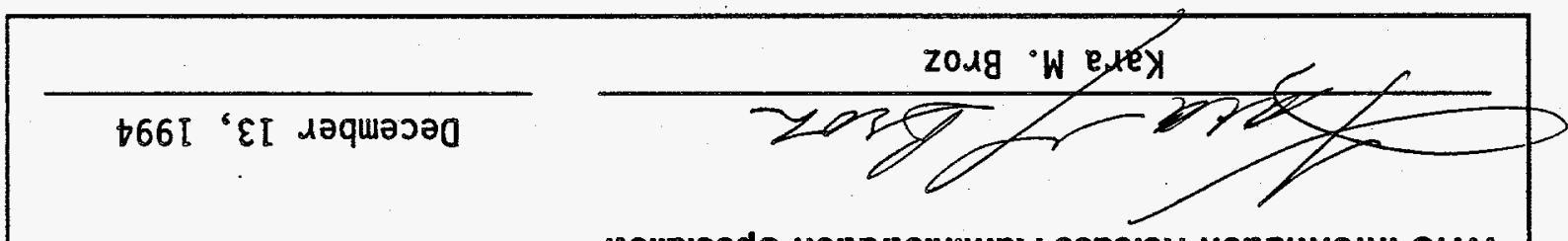

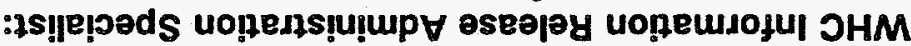

$\exists S \forall \exists 7 \exists y$ JI7gnd yOJ $0 \exists \wedge 0 y d d \forall$

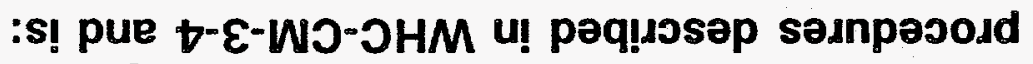

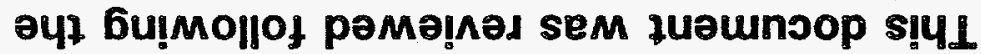

t66โ ' $\varepsilon \llbracket$ גəquəวə0

:әңеa әseәру

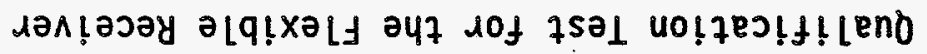

:อp!1 นuขunsog

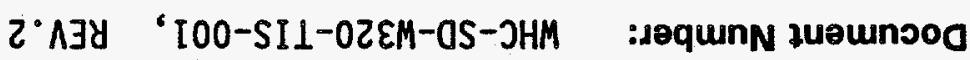

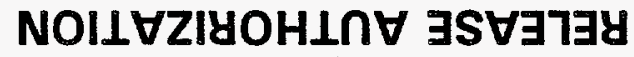




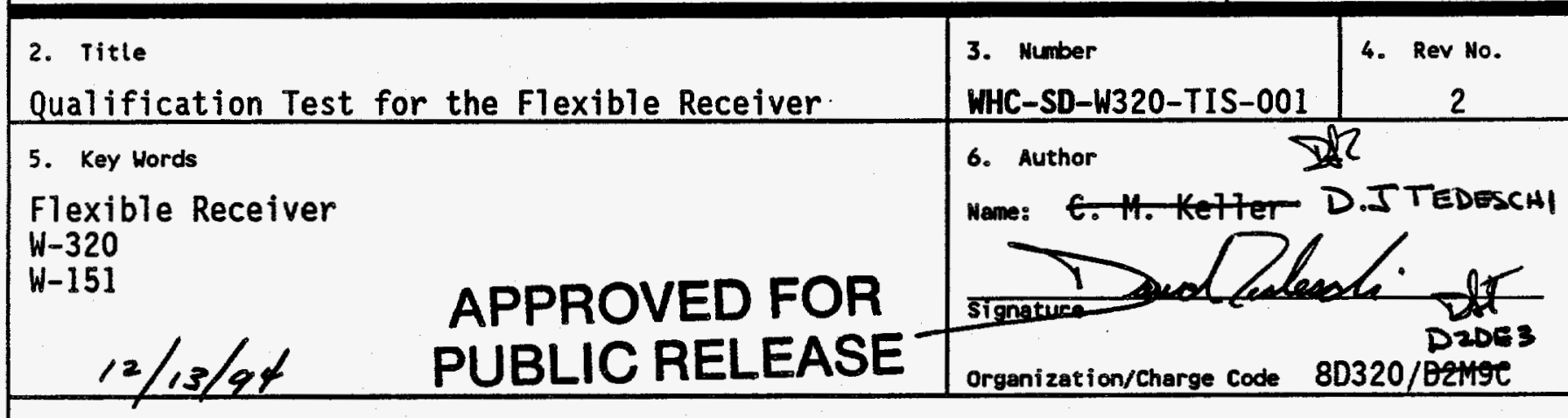

\section{Abstract}

This document provides the test $\mathrm{plan}$ and procedures to certify and design verify the 42" and 4"-6" Flexible Receiver as a safety class 3 system. The Flexible Receiver will be used by projects $W-151$ and $W-320$ for removing equipment from tanks $C-106$ and $A Z-101$. 
(2) Title

Qualification Test for the Flexible Receiver

CHANGE CONTROL RECORD

\begin{tabular}{|c|c|c|c|}
\hline \multirow{2}{*}{ Revision } & \multirow{2}{*}{ (4) Description of Change - Replace, Add, and Delete Pages } & \multicolumn{2}{|c|}{ Authorized for Release } \\
\hline & & (5) Cog. Engr. & (6) Cog. Mgr. \\
\hline 1 & $\begin{array}{l}\text { (7) Revised test procedure steps to } \\
\text { incorporate changes per dry-run } \\
\text { testing. } \quad \text { ECN } 617551 \\
\end{array}$ & DE Legare & RK Brown \\
\hline 258 & $\begin{array}{l}\text { Revised test procedure steps to incorporate } \\
\text { changes per dry-run testing and to } \\
\text { incorporate the } 42^{\prime \prime} \text { Flexible Receiver } \\
\text { Qualification Test. ECN }-617567\end{array}$ & DE Legare & RK Brown \\
\hline & & & \\
\hline & & & \\
\hline & & & \\
\hline & & & \\
\hline & & & \\
\hline & . & & \\
\hline & & & \\
\hline & & & \\
\hline & & & \\
\hline & & & \\
\hline & & & \\
\hline & & & \\
\hline & & & \\
\hline & & & \\
\hline & & & \\
\hline & . & & \\
\hline & & & \\
\hline & & & \\
\hline & & & \\
\hline & & & \\
\hline & & & \\
\hline & & & \\
\hline . & & & \\
\hline & & & \\
\hline & & & \\
\hline & & & \\
\hline & & & \\
\hline & & & \\
\hline
\end{tabular}




\title{
QUALIFICATION TEST FOR THE FLEXIBLE RECEIVER
}

\author{
WHC-SD-W320-TIS-001 Rev 2
}

December 12, 1994

\section{DISCLAIMER}

This report was prepared as an account of work sponsored by an agency of the United States Government. Neither the United States Government nor any agency thereof, nor any of their employees, makes any warranty, express or implied, or assumes any legal liability or responsibility for the accuracy, completeness, or usefulness of any information, apparatus, product, or process disclosed, or represents that its use would not infringe privately owned rights. Reference herein to any specific commercial product, process, or service by trade name, trademark, manufacturer, or otherwise does not necessarily constitute or imply its endorsement, recommendation, or favoring by the United States Government or any agency thereof. The views and opinions of authors expressed herein do not necessarily state or reflect those of the United States Government or any agency thereof.

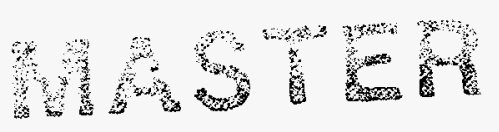


APPROVAL/SIGNATURE PAGES

1.0 TEST ITEM IDENTIFICATION ................. 24

1.1 FLEXIBLE RECEIVER ..................... 24

2.0 GENERAL DESCRIPTION . . . . . . . . . . . . . 29

2.1 TEST OBJECTIVES ....................... 29

3.0 TEST CONDITION LIMITS . . . . . . . . . . . . . . 29

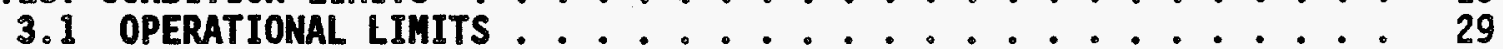

3.2 ENVIRONMENTAL LIMITS ................ 30

4.0 FACILITIES, EQUIPMENT, AND MATERIALS . . . . . . . 30

4.1 TEST FACILITY . . . . . . . . . . . . . . . 30

4.2 EQUIPMENT $\ldots \ldots \ldots$

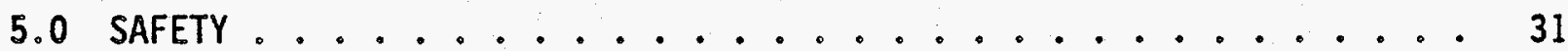

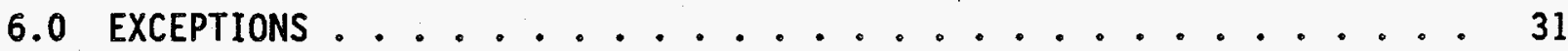

7.0 PERSONMEL REQUIREMENTS .................. 32

7.1 GENERAL $\ldots \ldots \ldots . \ldots . \ldots . \ldots . \ldots$

7.2 TEST DIRECTOR . . . . . . . . . . . 32

7.3 WITNESSES .......................... 33

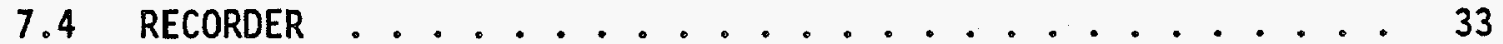

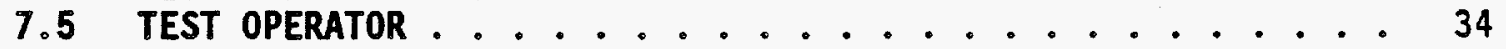

8.0 TEST PROCEDURE . . . . . . . . . . . . . . . 34

8.1 GENERAL SYSTEM REQUIREMENTS $\ldots \ldots \ldots \ldots . \ldots . \ldots . \ldots$

8.2 TEST CONDITIONS ..................... 35

8.3 OPERATIONAL SEQUENCE ................. 36

8.3.1 Start Up Sequence ............... . 36

8.3.2 Flexible Receiver Sequence $\ldots \ldots . \ldots 39$

8.3.3 Secondary Bagger Operations .......... 48

8.3 .4 Manual Control .............. 50

8.3.5 Master Reset. . . . . . . . . . . . 53

9.0 REFERENCES ........................ 53

9.1 DRAWINGS ....................... 53

9.2 VENDOR INFORMATION ..................... 54

9.3 OTHER INFORMATION .......................... 54

10.0 DATA SHEETS . . . . . . . . . . . . . . . 54

10.1 TEST EXCEPTION SHEET $\ldots \ldots \ldots \ldots$

10.2 TEST LOG SHEET ................. 57

$11.04 / 6 "$ FLEXIBLE RECEIVER SYSTEMS TEST PROCEDURE . . . . . . . . 59

11.1 GENERAL SYSTEM REQUIREMENTS . . . . . . . . . . . 59

11.1 .1 TEST CONDITIONS .................... 59 


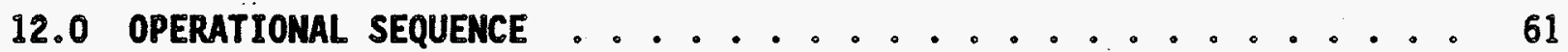

12.1 START UP SEQUENCE $\ldots \ldots \ldots \ldots$

12.2 Flexible Receiver Sequence ............. 63

12.3 SECONDARY BAGGER OPERATIONS ............. 69

Appendix A. 42* FR Approved/Performed Test Procedures and Exceptions 


\section{List of Figures}

1. Flexible Receiver Systems . . . . . . . 26

2. Typical 42" Flexible Receiver Located On A Tank . . . . . . . 27

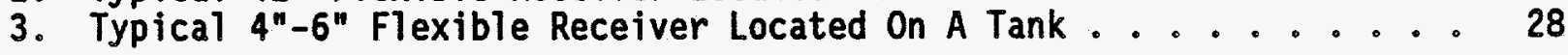


WHC-SD-W320-TIS-001 Rev 2

December 12, 1994

Page i

PERSONNEL INVOLVED IN THE QUALIFICATION TESTING

OF THE 42" FLEXIBLE RECEIVER

ALL NAMES ON THIS PAGE ARE TO BE PRINTED, SIGNED, AND INITIALED FOR CLARIFICATION.

EXECUTED BY:

Test Director/Organization Date

Test Operator/Organization Date

Recorder/Organization

Date

Test Operator/Organization Date

WITNESSES:

Witness/Organization Date

Witness/Organization

Date

Witness/Organization

Date

Witness/Organization

Date 
PERSONNEL INVOLVED IN THE QUALIFICATION TESTING

OF THE $4^{n}-6^{n}$ FLEXIBLE RECEIVER

ALL NAMES ON THIS PAGE ARE TO BE PRINTED, SIGNED, AND INITIALED FOR CLARIFICATION.

EXECUTED BY:

Test Director/Organization Date

Test Operator/Organization Date

Recorder/Organization

Date

Test Operator/Organization Date

WITNESSES:

Witness/Organization Date

Witness/Organization Date

Witness/Organization

Date

Witness/Organization

Date 
WHC-SD-W320-TIS-001 Rev 2

December 12, 1994

Page $\mathrm{i} i \mathrm{i}$

TEST APPROVAL AND ACCEPTANCE OF 42" FLEXIBLE RECEIVER

These signatures approve with exceptions that the $42^{\prime \prime}$ Flexible Receiver is qualified for use in the field based on the results from these tests.

Test Director Date

Cognizant Engineer Date

Quality

Date

Date

Comments: 
WHC-SD-W320-TIS-001 ReV 2

December 12, 1994

Page iv

TEST APPROVAL AND ACCEPTANCE OF 4"-6" FLEXIBLE RECEIVER

These signatures approve with exceptions that the $4^{11}-6^{n}$ Flexible Receiver is qualified for use in the field based on the results from these tests.

Test Director

Date

Cognizant Engineer

Date

QuaTity

Date

Date

Comments: 


\section{PURPOSE AND SCOPE OF DOCUMENT}

This document provides the test $\mathrm{plan}$ and procedures to certify and design verify the $42^{\prime \prime}$ and $4^{\prime \prime}-6^{\prime \prime}$ Flexible Receiver (FR) as a safety class 3 system. Verification of the design will be handled in two parts. The first part will be to show that it meets design requirements set forth by documents and the second part will perform test(s) to verify its operational aspects.

\section{PART I DESIGN VERIFICATION BASED ON REQUIREMENTS}

The following is a table that defines the documents, their requirements, and specifies FR compliance.

\begin{tabular}{|c|c|c|c|}
\hline $\begin{array}{l}\text { Item } \\
\text { No. }\end{array}$ & Document and Requirement & $\begin{array}{l}\text { Comply } \\
\text { Y or } N\end{array}$ & Remarks or Comments \\
\hline 1 & $\begin{array}{l}\text { WHC-CM-6.1 EP } 1.4 \text { APPENDIX } \\
\text { B } \\
\text { Safety class } 3 \text { and non-safety } \\
\text { class } 4 \text { items must meet the } \\
\text { requirements of DOE Order } \\
6430 \text {.1A for non-safety class } \\
\text { facilities and SDC } 4.1 \text {. } \\
\text { Applicable conventional } \\
\text { standards shall be applied to } \\
\text { safety class } 3 \text { items. }\end{array}$ & $Y$ & $\begin{array}{l}\text { This system has met the applicable } \\
\text { requirements of DOE } 6430.1 A \text {. All } \\
\text { trailers have been designed to the } \\
\text { requirements of SDC } 4.1 \text {. For the } \\
\text { new trailer: Per H-2-78935 rev } 2 \text {, } \\
\text { the trailer is purchased to meet } \\
\text { the requirements of SDC } 4.1 \text {. } \\
\text { For the retrofit trailer: This } \\
\text { trailer was designed and } \\
\text { constructed and reevaluated for SDC } \\
4.1 \text { per WHC-SD-WM-SA-089. } \\
\text { For the Flexible Receiver: This } \\
\text { has been designed for a } 70 \text { MPH (UBC } \\
\text { requirement) wind and will } \\
\text { withstand it per WHC-SD-W151-DA- } \\
\text { o03. All other design factors } \\
\text { (snow, earthquake, ash) are less } \\
\text { severe and are therefore covered by } \\
\text { the wind load evaluation. } \\
\text { Applicable industrial type } \\
\text { standards have been used (as shown } \\
\text { in the FDC's for both Project W320 } \\
\text { and WI51) to meet the requirements } \\
\text { for a safety class } 3 \text { piece of } \\
\text { equipment. }\end{array}$ \\
\hline
\end{tabular}

This is a total rewrite, therefore, revision bars were not used. 


\begin{tabular}{|c|c|c|c|}
\hline $\begin{array}{l}\text { Item } \\
\text { No. }\end{array}$ & Document and Requirement & $\begin{array}{l}\text { Comply } \\
Y \text { or } N\end{array}$ & Remarks or Comments \\
\hline 2 & $\begin{array}{l}\frac{W H C-C M-6.1 \text { EP 2.1 }}{\text { Software is managed in }} \\
\text { accordance to EP 2.1 }\end{array}$ & $Y$ & $\begin{array}{l}\text { There are two types of software } \\
\text { used on the flexible receiver. 1) } \\
\text { Ladder logic that controls the } \\
\text { receiver systems for bagging. This } \\
\text { is documented in the "Software } \\
\text { Configuration Management Plan For } \\
\text { The Flexible Receiver Control } \\
\text { System" WHC-SD-W151-CSCM-001, Rev } \\
0 \text {. 2) VAX software and program } \\
\text { used in the GAMMA ASSAY. This } \\
\text { software manipulates and processes } \\
\text { information sent from the probes } \\
\text { via the nucleonics. Each software } \\
\text { will have a table of description to } \\
\text { fill out on it. }\end{array}$ \\
\hline 3 & $\begin{array}{l}\text { WHC-CM-1-3 MRP } 5.46 \text { REV } 4 \\
\text { Safety class } 3 \text { items shal1 be } \\
\text { incorporated into safety } \\
\text { equipment } 1 \text { ists individually } \\
\text { or by reference to the system } \\
\text { including the subject item. } \\
\text { A system reference implies } \\
\text { that all items in the system } \\
\text { are Safety Class } 3 .\end{array}$ & $Y$ & $\begin{array}{l}\text { The PSAR (WHC-SD-W151-PSAR-001 Rev } \\
0 \text { for Project W151 views the } \\
\text { flexible receiver as a system and } \\
\text { classifies it as safety class } \\
\text { three. Project W320 also covers } \\
\text { this as a system in the Preliminary } \\
\text { Safety Evaluation WHC-SD-WM-PSE- } \\
\text { O10. }\end{array}$ \\
\hline 4 & $\begin{array}{l}\text { WHC-CM-1-3 MRP } 5.46 \text { REV } 4 \text { OA } \\
\text { Requirements } \\
\text { As a minimum, conventional } \\
\text { industrial standards (NEC, } \\
\text { NFPA, Mil Stds ...) shall be } \\
\text { appl ied to WHC safety class } 3 \\
\text { items. }\end{array}$ & $Y$ & Same as in item 1. \\
\hline$=$ & ave been & rom & ev. 2. Oni \\
\hline
\end{tabular}




\begin{tabular}{|c|c|c|c|}
\hline $\begin{array}{l}\text { Item } \\
\text { No. }\end{array}$ & Document and Requirement & $\begin{array}{l}\text { Comply } \\
\text { Y or } N\end{array}$ & Remarks or Comments \\
\hline 5 & $\begin{array}{l}\text { sect } 2.2 .4 \text { The retrieval } \\
\text { system shall be designed to } \\
\text { minimize the generation of } \\
\text { new liquid waste created as a } \\
\text { result of the retrieval } \\
\text { operations. }\end{array}$ & $\gamma$ & $\begin{array}{l}\text { The only waste the system will } \\
\text { produce will be in the washing of } \\
\text { equipment as it is being pulled } \\
\text { out. Hot water will spray out of a } \\
\text { ring of nozzles at } 50 \text { gpm (max), } \\
\text { then it is routed into the tank. } \\
\text { The amount of water expected to be } \\
\text { used will be } 2500 \text { ( } \pm 500 \text { ) gallons } \\
\text { for a } 50 \text { foot } 1 \text { ong piece of } \\
\text { equipment at an extrusion rate of } 1 \\
\text { ft per minute. See FDC WHC-S-037. }\end{array}$ \\
\hline 6 & $\begin{array}{l}\text { sect } 2.2 .4 \text { The retrieval } \\
\text { equipment shall be remotely } \\
\text { operable from a control room } \\
\text { located outside the Tank Farm } \\
\text { radiation zone. }\end{array}$ & $Y$ & $\begin{array}{l}\text { This requirement was clarified in } \\
\text { Internal Memo 7F820-94-008, Project } \\
93 L-E W W-320 \text {, Tank } 241-C-106 \\
\text { Sluicing, Letter of Clarification, } \\
\text { Equipment Removal System Control } \\
\text { Trailer Requirements to pertain to } \\
\text { only the control room for the tank } \\
\text { waste sluicing operation. The } \\
\text { clarification excludes the } \\
\text { Equipment Removal System from this } \\
\text { requirement. Since the Flexible } \\
\text { Receiver is part of the Equipment } \\
\text { Removal System it is not required } \\
\text { that its control trailer be located } \\
\text { outside the Tank Farm radiation } \\
\text { zone. The Flexible Receiver } \\
\text { control trailer will be located } \\
\text { approximately } 100 \text { ft away from the } \\
\text { area of equipment operation. }\end{array}$ \\
\hline 7 & $\begin{array}{l}\text { sect } 2.2 .4 \text { Systems operation } \\
\text { shall be in accordance with } \\
\text { ALARA principles. }\end{array}$ & $\gamma$ & $\begin{array}{l}\text { This operation will be remotely } \\
\text { handled such that few if any } \\
\text { person(s) will need to be close to } \\
\text { the actual operation. Emergency } \\
\text { devices, such as in the event the } \\
\text { bag does not get fully cut and it } \\
\text { will be necessary to manually cut } \\
\text { the bag, will account for } \\
\text { minimizing distance by placing tool } \\
\text { on an extension rod. }\end{array}$ \\
\hline
\end{tabular}




\begin{tabular}{|c|c|c|c|}
\hline $\begin{array}{l}\text { Item } \\
\text { No. }\end{array}$ & Document and Requirement & $\begin{array}{l}\text { Comply } \\
\text { Y or } N\end{array}$ & Remarks or Comments \\
\hline 8 & $\begin{array}{l}\text { sect } 2.2 .4 \text { Human factors } \\
\text { engineering shall be } \\
\text { performed in accordance with } \\
\text { DOE Order } 6430.1 \mathrm{~A} \text {, General } \\
\text { Design Criteria (DOE 1989), } \\
\text { to enhance assembly, } \\
\text { operation, maintenance, and } \\
\text { disassembiy of the retrieval } \\
\text { system, and to minimize the } \\
\text { potential for operator error. }\end{array}$ & Y & $\begin{array}{l}\text { This feature will only apply to the } \\
\text { controls and trailer used to house } \\
\text { the controls. The controls were } \\
\text { designed to NUREG } 0700 \text { per DOE } \\
\text { Order } 6403.1 \text { a guidance. The } \\
\text { trailer will also meet this } \\
\text { document. }\end{array}$ \\
\hline 9 & $\begin{array}{l}\text { sect } 2.2 .6 \text { All structures } \\
\text { and components that are } \\
\text { intended for installation and } \\
\text { removal via crane shall have } \\
\text { their weight permanently and } \\
\text { prominently marked on the } \\
\text { item and indicated on the } \\
\text { definitive design media. All } \\
\text { structures and components } \\
\text { that are intended for } \\
\text { hands-on installation and } \\
\text { removal (e.g., pit valve } \\
\text { handles, inspection port } \\
\text { plugs, etc.) shall have their } \\
\text { weight permanently and } \\
\text { prominently marked on the } \\
\text { item and indicated on the } \\
\text { definitive design media. }\end{array}$ & $\mathbf{P}$ & In progress \\
\hline 10 & $\begin{array}{l}\text { sect } 2.2 .6 \text { The WRSS shall be } \\
\text { designed to comply with all } \\
\text { onsite packaging and shipping } \\
\text { requirements. The scope of } \\
\text { the activity shall include } \\
\text { features which facilitate } \\
\text { removal and disposal of the } \\
\text { waste retrieval equipment. }\end{array}$ & Y & $\begin{array}{l}\text { See PDC WHC-SD-TP-PDC-015 on } \\
\text { packaging. }\end{array}$ \\
\hline
\end{tabular}




\begin{tabular}{|c|c|c|c|}
\hline $\begin{array}{l}\text { Item } \\
\text { No. }\end{array}$ & Document and Requirement & $\begin{array}{l}\text { Comply } \\
\text { Y or } N\end{array}$ & Remarks or Comments \\
\hline 11 & $\begin{array}{l}\text { sect } 3.1 \text { The instrument and } \\
\text { control system shall monitor } \\
\text { and control the facility } \\
\text { retrieval and transfer } \\
\text { options, HVAC, and support } \\
\text { systems to perform all } \\
\text { functions necessary to } \\
\text { retrieve the contents of the } \\
\text { tank and transport the } \\
\text { material to its new holding } \\
\text { facility. }\end{array}$ & $Y$ & $\begin{array}{l}\text { Ladder logic coupled with a } \\
\text { programmable logic controller, } \\
\text { monitor and control the process of } \\
\text { pulling an object out of the tank } \\
\text { into the bag. These operations are } \\
\text { remotely controlled and visually } \\
\text { observed by } 3 \text { cCTV cameras on the } \\
\text { receiver. All controls for the FR } \\
\text { are located in a trailer. }\end{array}$ \\
\hline 12 & $\begin{array}{l}\text { sect } 4.5 \text { Electrical } \\
\text { enclosures, junction boxes, } \\
\text { and pull boxes shall meet the } \\
\text { requirements of the } \\
\text { environment in which the } \\
\text { housings are installed. }\end{array}$ & $Y$ & $\begin{array}{l}\text { All boxes exposed to the } \\
\text { environment will be constructed } \\
\text { using NEMA } 4 \text { type enclosures. This } \\
\text { applies to box(s) on the new } \\
\text { trailer (see drawing } H-2-78935 \text { ) and } \\
\text { actual hardware from the retrofit } \\
\text { grout trailer. }\end{array}$ \\
\hline 13 & $\begin{array}{l}\text { sect } 4.7 \text { General design } \\
\text { guidelines for energy } \\
\text { conservation shall comply } \\
\text { with the following sections } \\
\text { of DOE Order } 6430.1 A \text { : } \\
\text { - 0110-12, "Energy } \\
\text { Conservation" } \\
\text { 1595-10, "Energy Management } \\
\text { Systems" } \\
\text { - 1595-11, "Interior } \\
\text { Electrical Power and Lighting } \\
\text { Systems" } \\
\text { The design must include an } \\
\text { energy conservation report in } \\
\text { accordance with D0E Order } \\
6430.1 A \text {, Section 0110-12.8. }\end{array}$ & Y & $\begin{array}{l}\text { No report will need to be written } \\
\text { per section } 0110-12.8 .1 \text { We will } \\
\text { not exceed } 500 \text { million BTUs (total } \\
\text { energy consumption) per year nor is } \\
\text { the trailer(s) greater than } 10,000 \\
\text { sq ft. No full blown analysis will } \\
\text { be done. An agreement was made not } \\
\text { to do a big analysis per telephone } \\
\text { conversation and cc mail to Bill } \\
\text { White of DOE-RL and WHC Energy } \\
\text { Management. The agreement was to } \\
\text { write a DSI to file (DSI-94-DJT- } \\
\text { ool) showing why no further } \\
\text { analysis will need to be done on } \\
\text { project } 151 \text { trailer. There will } \\
\text { not be any more analysis done on } \\
\text { the trailer taken from grout since } \\
\text { its not changing the trailer } \\
\text { structure or its support equipment. }\end{array}$ \\
\hline
\end{tabular}


WHC-SD-W320-TIS-001 ReV 2

December 12, 1994

Page 6

\begin{tabular}{|c|c|c|c|}
\hline $\begin{array}{l}\text { Item } \\
\text { No. }\end{array}$ & Document and Requirement & $\begin{array}{l}\text { Comply } \\
Y \text { or } N\end{array}$ & Remarks or Comments \\
\hline 14 & $\begin{array}{l}\text { sect } 4.8 .2 \text { Provisions for } \\
\text { remote replacement of system } \\
\text { equipment that operates in } \\
\text { high-radiation zone shal1 be } \\
\text { made as required to meet } \\
\text { ALARA criteria (see } \\
\text { DOE/EV/1830-T5, A Guide to } \\
\text { Reducing Radiation Exposure } \\
\text { to as Low as Reasonably } \\
\text { Achievable [ALARA] [DOE } \\
\text { 1980]). The capability shall } \\
\text { be provided to perform a } \\
\text { preliminary decontamination, } \\
\text { where practical, of equipment } \\
\text { before repair or removal. }\end{array}$ & $\begin{array}{r}Y \\
-Y\end{array}$ & $\begin{array}{l}\text { ALARA has been employed when } \\
\text { operating the equipment and when } \\
\text { placing it too. There are no } \\
\text { sources of exposure when placing } \\
\text { the receiver equipment with the } \\
\text { exception of possible airborne } \\
\text { contaminants from opening the } \\
\text { riser. Operation of the FR is } \\
\text { performed remotely in a trailer } \\
\text { away from the equipment being } \\
\text { removed (source of radiation). A } \\
\text { spray wash system has been } \\
\text { incorporated to partially } \\
\text { decontaminate the equipment to be } \\
\text { removed from the tanks. There is } \\
\text { adequate provision for } \\
\text { decontaminating the inside of the } \\
\text { receiver before removing. The } \\
\text { receiver has several access ports } \\
\text { which have the potential to be used } \\
\text { for decontaminating the internal } \\
\text { surfaces of the FR. }\end{array}$ \\
\hline 15 & $\begin{array}{l}\text { sect } 4.8 .2 \text { All mechanical } \\
\text { equipment, windows, cameras, } \\
\text { television monitors, and } \\
\text { other equipment in areas of } \\
\text { potential radioactivity } \\
\text { shall, where practical, be } \\
\text { sealed or otherwise protected } \\
\text { from penetration by } \\
\text { contamination and } \\
\text { decontamination solutions. }\end{array}$ & $Y$ & $\begin{array}{l}\text { All joints, unions, or access ports } \\
\text { that are exposed to the removed } \\
\text { equipment have seals. }\end{array}$ \\
\hline 16 & $\begin{array}{l}\text { sect } 4.8 .2 \text { All electrical } \\
\text { and instrumentation equipment } \\
\text { shall be properly grounded } \\
\text { for safety of personnel and } \\
\text { protection of equipment. }\end{array}$ & Y & $\begin{array}{l}\text { A11 electrical equipment has been } \\
\text { designed per the NEC code. All } \\
\text { equipment has been properly } \\
\text { grounded. See H-2-98937 }\end{array}$ \\
\hline
\end{tabular}




\begin{tabular}{|c|c|c|c|}
\hline $\begin{array}{l}\text { Item } \\
\text { No. }\end{array}$ & Document and Requirement & $\begin{array}{l}\text { Comply } \\
\text { Y or } N\end{array}$ & Remarks or Comments \\
\hline 17 & $\begin{array}{l}\text { sect } 4.8 .3 \text { Materials shall } \\
\text { be compatible with the } \\
\text { exposed environment. } \\
\text { Installed materials shall be } \\
\text { (1) resistant to radiation, } \\
\text { process solutions, acid and } \\
\text { caustic vapors and solutions, } \\
\text { and known decontamination } \\
\text { agents; (2) nonabsorbent, } \\
\text { easily removable if not } \\
\text { contamination resistant; } \\
\text { and/or (3) oversized to } \\
\text { permit partial destruction } \\
\text { without affecting structural } \\
\text { integrity. }\end{array}$ & $Y$ & $\begin{array}{l}\text { The environmental conditions that } \\
\text { receiver equipment material will be } \\
\text { exposed to is the following: 1) } \\
\text { normal desert weather, 2) hot } \\
\text { water, and } 3 \text { ) radiation. All } \\
\text { components exposed to the weather } \\
\text { are weather proofed. Critical } \\
\text { components, such as hydraulic } \\
\text { piping have been designed to } \\
\text { account for corrosion by being } \\
\text { fabricated from stainless steel. } \\
\text { The interior of the receiver will } \\
\text { see the worst conditions which } \\
\text { includes the hot water and } \\
\text { radiation. All equipment exposed } \\
\text { to these conditions has been } \\
\text { designed to endure such an } \\
\text { environment. Note that radiation } \\
\text { levels may be high, but exposure } \\
\text { time is low, which precludes that } \\
\text { material that is normally not so } \\
\text { conducive to the radiation will } \\
\text { still be acceptable. Also, use of } \\
\text { the receiver equipment will be } \\
\text { limited. See drawing } H-2-79310 \text {, } \\
79320,79362 \text { for parts } 1 \text { ists. }\end{array}$ \\
\hline 18 & $\begin{array}{l}\text { sect } 5.1 .2 \\
\text { analysis sha } 11 \text { be conducted } \\
\text { in accordance DOE Order } 5480 \\
\text { and } 6430 .\end{array}$ & Y & $\begin{array}{l}\text { See WHC-SD-WM-PSE-010 for project } \\
\text { W320 and WHC-SD-W151-PSAR-001 for } \\
\text { W151. }\end{array}$ \\
\hline
\end{tabular}




\begin{tabular}{|c|c|c|c|}
\hline $\begin{array}{l}\text { Item } \\
\text { No. }\end{array}$ & Document and Requirement & $\begin{array}{l}\text { Comply } \\
Y \text { or } N\end{array}$ & Remarks or Comments \\
\hline 19 & $\begin{array}{l}\text { sect } 5.1 .3 \text { The retrieval } \\
\text { system shal1 be designed to } \\
\text { confine contaminants within } \\
\text { the combination of boundaries } \\
\text { defined by the existing tank, } \\
\text { the confinement surfaces of } \\
\text { the retrieval system, and any } \\
\text { other barriers that may be } \\
\text { required. A system shall be } \\
\text { employed to control } \\
\text { contamination caused by a } \\
\text { failure of the primary } \\
\text { confiner or other off-normal } \\
\text { situation. }\end{array}$ & $Y$ & $\begin{array}{l}\text { The tank ventilation system is a } \\
\text { method of contamination control } \\
\text { should a failure of the primary } \\
\text { confiner (open riser, or failed } \\
\text { Flexible Receiver bag) occur. The } \\
\text { draft Safety Assessment, WHC-SD-WM- } \\
\text { SAD-024, Rev. A (approval expected } \\
\text { by } 10 / 94 \text { ), states that dose } \\
\text { consequences due to an open riser } \\
\text { condition with a failed tank } \\
\text { ventilation system is within the } \\
\text { acceptance guidelines of WHC-CM-4- } \\
46 \text { for a period of at least } 8 \text { hours } \\
\text { on tank C-106. }\end{array}$ \\
\hline 20 & $\begin{array}{l}\text { sect } 5.1 .3 \text { The retrieval } \\
\text { system shall have provisions } \\
\text { for safe and effective } \\
\text { decontamination (see } \\
\text { Section } 5.8 \text { ) The design of } \\
\text { the WRSS shall facilitate } \\
\text { decontamination so that the } \\
\text { facility can be } \\
\text { decommissioned at a future } \\
\text { date. Guidance for retrieval } \\
\text { equipment design to } \\
\text { facilitate eventual } \\
\text { decommissioning shall be } \\
\text { obtained from DoE Order } \\
4700.1 \text { Project Management } \\
\text { System (DOE 1987); ANSI } \\
\text { N300-1975, Design Criteria } \\
\text { for Decommissioning of } \\
\text { Nuclear Fuel Reprocessing } \\
\text { Plants (ANSI 1975); and DOE } \\
\text { Order } 6430.1 \text {, General Design } \\
\text { Criteria, Sections 1300-11.2 } \\
\text { and 1321-7 (DOE 1989). }\end{array}$ & $\gamma$ & $\begin{array}{l}\text { The retrieval system will spray } \\
\text { down the equipment with } 150^{\circ} \mathrm{F} \text { hot } \\
\text { water at } 3000 \text { psi. All the } \\
\text { contaminated water will return to } \\
\text { the tank. Everything is sealed both } \\
\text { with a vacuum from the tank and } \\
\text { joints with waterproof seals. The } \\
\text { Flexible Receiver has severai } \\
\text { access ports which, if needed, } \\
\text { provide the ability to } \\
\text { decontaminate its internal } \\
\text { surfaces. }\end{array}$ \\
\hline
\end{tabular}




\begin{tabular}{|c|c|c|c|}
\hline $\begin{array}{l}\text { Item } \\
\text { No. }\end{array}$ & Document and Requirement & $\begin{array}{l}\text { Comply } \\
Y \text { or } N\end{array}$ & Remarks or Comments \\
\hline 21 & $\begin{array}{l}\text { sect } 5.1 .6 \\
\text { systems in temporary } \\
\text { facilities provided by this } \\
\text { project, e.g., the sluicing } \\
\text { control room, shall be } \\
\text { designed to meet the } \\
\text { following applicable } \\
\text { requirements: } \\
\text { DOE/EV-0043, standards on } \\
\text { Fire Protection for Portable } \\
\text { Structures (DOE 1979) }\end{array}$ & $Y$ & $\begin{array}{l}\text { This section is applicable only to } \\
\text { the control trailer but is exempted } \\
\text { per Internal Memo 7F520-MEM-94-002, } \\
\text { M. E. Manthei to D. E. Legare, } \\
\text { "Project W-151, Tank 101-AZ Waste } \\
\text { Retrieval System, Fire Suppression } \\
\text { for Flexible Receiver Control } \\
\text { Trailers," dated February 15, 1994; } \\
\text { and, DOE Letter 94-PRJ-045, R. W. } \\
\text { Brown, DOE, to President, WHC, } \\
\text { "Flexible Receiver Control Trailer, } \\
\text { Concurrence for Interpretation of } \\
\text { DOE Standard EV-0043, 'Standard on } \\
\text { Fire Protection for Portable } \\
\text { Structures', August 1979", dated } \\
\text { June 3, 1994 (distributed by CCRN } \\
\text { \#9403731). }\end{array}$ \\
\hline 22 & $\begin{array}{l}\text { sect } 5.1 .6 \\
\text { system shal1 be compatible } \\
\text { with, and tie into, the } \\
200 \text { Area Hanford Site radio } \\
\text { fire alarm system. }\end{array}$ & $Y$ & $\begin{array}{l}\text { This section is applicable only to } \\
\text { the control trailer but is exempted } \\
\text { per Internal Memo 7F520-MEM-94-002, } \\
\text { M. E. Manthei to D. E. Legare, } \\
\text { "Project W-151, Tank 101-AZ Waste } \\
\text { Retrieval System, Fire Suppression } \\
\text { for Flexible Receiver Control } \\
\text { Trailers," dated February 15, 1994; } \\
\text { and, DOE Letter 94-PRJ-045, R. W. } \\
\text { Brown, D0E, to President, WHC, } \\
\text { "Flexible Receiver Control Trailer, } \\
\text { Concurrence for Interpretation of } \\
\text { DOE Standard EV-0043, 'Standard on } \\
\text { Fire Protection for Portable } \\
\text { Structures', August 1979", dated } \\
\text { June 3, 1994 (distributed by CCRN } \\
\text { \#9403731). }\end{array}$ \\
\hline
\end{tabular}




\begin{tabular}{|c|c|c|c|}
\hline $\begin{array}{l}\text { Item } \\
\text { No. }\end{array}$ & Document and Requirement & $\begin{array}{l}\text { Comply } \\
Y \text { or } N\end{array}$ & Remarks or Conments \\
\hline 23 & $\begin{array}{l}\text { sect } 5.4 .1 \\
\text { structures of all systems } \\
\text { shall be designed for a DBE } \\
\text { as specified in HPS-SDC-4.1, } \\
\text { "Design Loads for Structures" } \\
\text { (DOE-RL 1988b), and DOE Order } \\
6430.1 A, \text { General Design } \\
\text { Criteria (DOE 1989), for } \\
\text { Safety Classes 1, 2, 3, and } \\
4 \text {. }\end{array}$ & $Y$ & $\begin{array}{l}\text { For the new trailer: Per H-2- } \\
78935 \text {, the trailer is purchased to } \\
\text { meet the requirements of SDC } 4.1 \text {. } \\
\text { For the retrofit trailer: This } \\
\text { trailer was designed and } \\
\text { constructed and reevaluated for SDC } \\
4.1 \text { per WHC-SD-WM-SA-089. } \\
\text { For the Flexible Receiver: This } \\
\text { has been designed for a } 70 \mathrm{MPH} \text { (UBC } \\
\text { requirement) wind and wi11 } \\
\text { withstand it per WHC-SD-W151-DA- } \\
\text { 003. All other factors (snow, } \\
\text { earthquake, ash) are not as severe } \\
\text { as wind so there was no need to } \\
\text { perform calculations. }\end{array}$ \\
\hline 24 & $\begin{array}{l}\text { sect } 5.4 .5 \text { The WRSS shall } \\
\text { incorporate features that } \\
\text { maintain the WRSS and waste } \\
\text { tank in a safe condition if a } \\
\text { design basis power failure } \\
\text { occurs. Safety and health of } \\
\text { the public and onsite } \\
\text { personnel shall be key } \\
\text { considerations in the design. }\end{array}$ & $Y$ & $\begin{array}{l}\text { An uninterruptible power supply is } \\
\text { provided for the Flexible Receiver } \\
\text { Control Panels with a generator for } \\
\text { backup power. This will maintain } \\
\text { equipment in a safe condition and } \\
\text { provide power for continuing } \\
\text { operation if a design basis power } \\
\text { failure occurs. }\end{array}$ \\
\hline 25 & $\begin{array}{l}\text { sect } 5.5 \\
\text { consider human factors for } \\
\text { maintenance and operations } \\
\text { activities, including a } \\
\text { control panel, equipment, } \\
\text { valve location and } \\
\text { orientation, secondary waste } \\
\text { handling, and facility } \\
\text { arrangement. The design } \\
\text { shall comply with DOE Order } \\
6430.1 \mathrm{~A} \text {, Section } 1300-12 \text {. }\end{array}$ & $Y$ & $\begin{array}{l}\text { This applies only to the controls } \\
\text { in the trailer which is being } \\
\text { constructed per NUREG } 0700 \text {. The } \\
\text { compliance check list for NUREG } \\
0700 \text { was filled out on the basis of } \\
\text { this equipment and for both W151 an } \\
\text { W320 trailers. Also, a system task } \\
\text { analysis of the operation was } \\
\text { performed to analyze operational } \\
\text { conditions and tasks. This process } \\
\text { will be continually evaluated } \\
\text { during the first several operations } \\
\text { so the we may improve those things } \\
\text { which play a hinderance in the } \\
\text { operation. }\end{array}$ \\
\hline
\end{tabular}




\begin{tabular}{|c|c|c|c|}
\hline $\begin{array}{l}\text { Item } \\
\text { No. }\end{array}$ & Document and Requirement & $\begin{array}{l}\text { Comply } \\
\text { Y or N }\end{array}$ & Remarks or Comments \\
\hline 26 & $\begin{array}{l}\text { sect } 5.8 \text { Modular, separable } \\
\text { confinements shall be used } \\
\text { for radioactive and other } \\
\text { hazardous materials to } \\
\text { preclude contamination of } \\
\text { fixed portions of the } \\
\text { structure. }\end{array}$ & $Y$ & $\begin{array}{l}\text { Most if any contaminants on the } \\
\text { flexible receiver will be located } \\
\text { within the portion that equipment } \\
\text { is removed. Decontamination of } \\
\text { this should be feasible since the } \\
\text { material is stainless steel. Any } \\
\text { seams or joints exposed to the } \\
\text { removed equipment will also be a } \\
\text { suspect for collection. This } \\
\text { equipment (after being once used) } \\
\text { will undergo some decontamination } \\
\text { but will more than likely be } \\
\text { classified as radiated equipment } \\
\text { and treated as such throughout its } \\
\text { life. }\end{array}$ \\
\hline 27 & $\begin{array}{l}\text { Sect } 5.8 \text { Surfaces should be } \\
\text { free of crevices, ledges, } \\
\text { and/or protrusions which } \\
\text { could collect radioactive } \\
\text { material. }\end{array}$ & Y & $\begin{array}{l}\text { Surfaces have been designed to } \\
\text { minimize the amount of crevices, } \\
\text { ledges, etc. }\end{array}$ \\
\hline 28 & $\begin{array}{l}\text { sect } 5.8 \text { Penetrations shall } \\
\text { be waterproofed for } \\
\text { protection during } \\
\text { decontamination efforts. }\end{array}$ & $Y$ & $\begin{array}{l}\text { All material exposed to both the } \\
\text { weather and the spray wash system } \\
\text { will be sealed to prevent any water } \\
\text { seepage. The primary and secondary } \\
\text { bags contain an absorbent (see H-2- } \\
\text { 79289) to ensure no dripping } \\
\text { occurs. }\end{array}$ \\
\hline 29 & $\begin{array}{l}\text { sect } 5.8 \text { Fixtures and } \\
\text { outlets shall be sealed. }\end{array}$ & $Y$ & See \# 15 remark. \\
\hline 30 & $\begin{array}{l}\text { sect } 5.8 \text { Adequate clearance } \\
\text { shall be provided for } \\
\text { transfer of equipment. }\end{array}$ & Y & Work will be taking place outdoors. \\
\hline 31 & $\begin{array}{l}\text { sect } 5.8 \text { Lifting lugs shall } \\
\text { be used on large tanks or } \\
\text { equipment. }\end{array}$ & Y & $\begin{array}{l}\text { There are several hoisting lifts on } \\
\text { various components of the receiver. } \\
\text { For example, the bag assembly, the } \\
\text { whole receiver assembly, or just } \\
\text { the cutter assembly can all be } \\
\text { individually lifted up on their } \\
\text { own. This applies to both the 42" } \\
\text { and the 4"-6" receivers. }\end{array}$ \\
\hline
\end{tabular}




\begin{tabular}{|c|c|c|c|}
\hline $\begin{array}{l}\text { Item } \\
\text { No. }\end{array}$ & Document and Requirement & $\begin{array}{l}\text { Comply } \\
Y \text { or } N\end{array}$ & Remarks or Comments \\
\hline 32 & $\begin{array}{l}\text { sect } 5.8 \text { Modular radiation } \\
\text { shielding shall be used in } \\
\text { lieu of or in addition to, } \\
\text { monolithic shielding walls. }\end{array}$ & N/A & $\begin{array}{l}\text { This will be determined by the } \\
\text { Radiation Work Permit and is not } \\
\text { applicable to the qualification of } \\
\text { the receiver. }\end{array}$ \\
\hline 33 & $\begin{array}{l}\text { Drawings shall comply to the } \\
\text { standards listed in WHC-CM-6- } \\
3 \text {. }\end{array}$ & $Y$ & $\begin{array}{l}\text { All Flexible Receiver drawings have } \\
\text { been drawn to the standards listed } \\
\text { in the manual with the exception of } \\
\text { the vendor supplied drawings of } \\
\text { high pressure pump trailer and the } \\
\text { old grout trailer. }\end{array}$ \\
\hline \multicolumn{4}{|c|}{$\begin{array}{l}\text { The following requirements are taken from WHC-SD-W151-SDRD-001, Supplemental } \\
\text { Design Requirements Document, 241-AZ-101 Waste Retrieval System. }\end{array}$} \\
\hline 34 & $\begin{array}{l}\text { 3.4.1.1 The Flexible } \\
\text { Receiver Assemblies shall be } \\
\text { designed to remove new and/or } \\
\text { existing profile and sludge } \\
\text { thermocouple trees; mixer } \\
\text { pumps and new/ existing } \\
\text { transfer pumps from the 101- } \\
\text { AZ tank. }\end{array}$ & $Y$ & $\begin{array}{l}\text { Drawings } \mathrm{H}-2-79222 \text { and } \mathrm{H}-2-79348 \\
\text { provide the Flexible Receiver } \\
\text { assemblies that will be used for } \\
\text { removing equipment from the 101-AZ } \\
\text { tank. }\end{array}$ \\
\hline 35 & $\begin{array}{l}\text { 3.4.1.2 Waste equipment } \\
\text { removed from the 101-AZ tank } \\
\text { will be placed into a sealed } \\
\text { flexible receiver for } \\
\text { containment of radioactive } \\
\text { and chemical contamination } \\
\text { during removal and transport. } \\
\text { The associated removal and } \\
\text { mounting equipment shall also } \\
\text { be designed to maintain } \\
\text { containment of radioactive } \\
\text { and chemical contamination } \\
\text { while equipment is being } \\
\text { removed from the tank. The } \\
\text { enclosure shall meet the } \\
\text { requirements of Radiological } \\
\text { Design, WHC-CM-4-9 and } \\
\text { Hanford Radioactive Solid } \\
\text { Waste Packaging, storage, and } \\
\text { Disposal Requirements, WHC- } \\
\text { EP-0063, Rev. } 3 \text {. }\end{array}$ & $\because$ & See Item $\# 10$ \\
\hline
\end{tabular}




\begin{tabular}{|c|c|c|c|}
\hline $\begin{array}{l}\text { Item } \\
\text { No. }\end{array}$ & Document and Requirement & $\begin{array}{l}\text { Comply } \\
\text { Y or } N\end{array}$ & Remarks or Comments \\
\hline 36 & $\begin{array}{l}\text { 3.4.1.3 Fire retardant } \\
\text { materials shall be used for } \\
\text { the flexible receiver } \\
\text { material. }\end{array}$ & $Y$ & $\begin{array}{l}\text { The Flexible Receiver is } \\
\text { constructed of stainless steel and } \\
\text { a flexible bag which meets the fire } \\
\text { protection requirements of MIL-C- } \\
\text { 43006 Type I. }\end{array}$ \\
\hline 37 & $\begin{array}{l}\text { 3.4.1.4 The receiver shall, } \\
\text { as a goal, have a leak rate } \\
\text { of less than } 0.3 \text { volume } \\
\text { percent per hour, for a } 12- \\
\text { hour period, at an initial } \\
\text { negative pressure } \\
\text { differential of } 4 \text { inches of } \\
\text { water. After bagging is } \\
\text { completed, the solid waste } \\
\text { article shall be placed into } \\
\text { a trough or similar container } \\
\text { to prevent any leakage of } \\
\text { waste to the surrounding } \\
\text { soil. The bag is only } \\
\text { intended for contamination } \\
\text { control during removal. }\end{array}$ & $\gamma$ & $\begin{array}{l}\text { The Flexible Receiver containment } \\
\text { is provided by impervious stainless } \\
\text { steel and receiver bags which are } \\
\text { leak tested to more stringent } \\
\text { criteria per } \mathrm{H}-2-79326 \text {. }\end{array}$ \\
\hline 38 & $\begin{array}{l}3.4 .1 .5 \text { Equipment will be } \\
\text { installed and removed using a } \\
\text { crane. }\end{array}$ & Y & $\begin{array}{l}\text { To be demonstrated in Qualification } \\
\text { Testing. }\end{array}$ \\
\hline 39 & $\begin{array}{l}3.4 .1 .6 \text { Removal equipment } \\
\text { wil1 require remote operation } \\
\text { from a distance to minimize } \\
\text { radiation exposure to } \\
\text { personnel. ALARA principles } \\
\text { shall be used at all times in } \\
\text { the design of the equipment. }\end{array}$ & $Y$ & $\begin{array}{l}\text { Equipment operation is performed } \\
\text { from inside the control trailer at } \\
\text { a remote location. }\end{array}$ \\
\hline 40 & $\begin{array}{l}3.4 .1 .7 \text { Design of the } \\
\text { flexible receiver shall allow } \\
\text { recovery action for failed } \\
\text { in-tank riser components in } \\
\text { high radiation areas which } \\
\text { may include remote } \\
\text { reinsertion of components. }\end{array}$ & $Y$ & $\begin{array}{l}\text { To be demonstrated in Qualification } \\
\text { Testing. }\end{array}$ \\
\hline
\end{tabular}


WHC-SD-W320-TIS-001 ReV 2

December 12, 1994

Page 14

\begin{tabular}{|c|c|c|c|}
\hline $\begin{array}{l}\text { Item } \\
\text { No. }\end{array}$ & Document and Requirement & $\begin{array}{l}\text { Comply } \\
Y \text { or } N\end{array}$ & Remarks or Comments \\
\hline 41 & $\begin{array}{l}3.4 .1 .8 \text { Removal equipment } \\
\text { must be operable in ambient } \\
\text { conditions from } 35^{\circ} \mathrm{F} \text { to } \\
120^{\circ} \mathrm{F} \text {. Equipment will not be } \\
\text { used during high wind, rain } \\
\text { or freezing conditions. }\end{array}$ & $Y$ & $\begin{array}{l}\text { Equipment has been designed for } \\
\text { these conditions. }\end{array}$ \\
\hline 42 & $\begin{array}{l}\text { 3.4.1.9 The Flexible } \\
\text { Receiver Assembly will } \\
\text { interface with the wash } \\
\text { assembly (section } 3.4 .3 \text { ) on } \\
\text { the riser. }\end{array}$ & $y$ & $\begin{array}{l}\text { To be demonstrated in Qualification } \\
\text { Testing. }\end{array}$ \\
\hline 43 & $\begin{array}{l}\text { 3.4.1.10 The lifting } \\
\text { mechanism hook speed shall } \\
\text { have a range of } 1-8 \mathrm{fpm} . \\
\text { Speed control shall be } \\
\text { obtained by modifying the } \\
\text { hydraulics of an existing } \\
\text { crane. The new speed control } \\
\text { system shall not el iminate or } \\
\text { reduce existing crane } \\
\text { capabilities. }\end{array}$ & Y & $\begin{array}{l}\text { This requirement is provided by the } \\
\text { "Specification for Modification to } \\
\text { Grove Crane at 1100" V-W151-0003. }\end{array}$ \\
\hline 44 & $\begin{array}{l}\text { 3.4.1.11 Hook speed, } \\
\text { position indicator, and hook } \\
\text { load with associated readout } \\
\text { (located in crane cab) shall } \\
\text { be provided for the existing } \\
\text { site crane. The equipment } \\
\text { mounted on the crane shall be } \\
\text { weatherproof. }\end{array}$ & $Y$ & $\begin{array}{l}\text { This requirement is provided by the } \\
\text { "Specification for Modification to } \\
\text { Grove Crane at 1100" V-W151-0003. }\end{array}$ \\
\hline 45 & $\begin{array}{l}\text { 3.4.1.12 Total weight of the } \\
\text { new components (to be lifted } \\
\text { as a unit) and the rigging } \\
\text { shall be within the capacity } \\
\text { of existing site cranes. }\end{array}$ & $Y$ & \\
\hline
\end{tabular}




\begin{tabular}{|c|c|c|c|}
\hline $\begin{array}{l}\text { Item } \\
\text { No. }\end{array}$ & Document and Requirement & $\begin{array}{l}\text { Comply } \\
Y \text { or } N\end{array}$ & Remarks or Comments \\
\hline 46 & $\begin{array}{l}\text { 3.4.1.13 A secondary } \\
\text { receiver bag assembly will be } \\
\text { secured around the bottom of } \\
\text { the primary flexible receiver } \\
\text { to contain residual } \\
\text { contamination between the } \\
\text { bottom of the primary } \\
\text { receiver bag and the cable } \\
\text { seal An absorbent material } \\
\text { will be placed in the bag to } \\
\text { absorb any liquid that may be } \\
\text { present. }\end{array}$ & Y & $\begin{array}{l}\text { Provided by the Flexible Receiver } \\
\text { Leak Containment Bag/Stand } \\
\text { Assemblies, H-2-79297 and } \\
\text { H-2-79362. Their function will be } \\
\text { demonstrated in Qualification } \\
\text { Testing. }\end{array}$ \\
\hline \multicolumn{4}{|c|}{ Spray Wash System, High Pressure Pump } \\
\hline 47 & $\begin{array}{l}\text { 3.4.2.1 Hot water shall be } \\
\text { furnished on site from the } \\
200 \text { Area boiler plant. The } \\
200^{\circ} \mathrm{F} \text { maximum water will be } \\
\text { tanker trucked to } 101-A Z \text {. }\end{array}$ & $Y$ & $\begin{array}{l}\text { To be demonstrated in Qualification } \\
\text { Testing. }\end{array}$ \\
\hline 48 & $\begin{array}{l}\text { 3.4.2.2 The high pressure } \\
\text { spray wash system supply } \\
\text { shall have an operating } \\
\text { discharge pressure of } 3000 \\
\text { psi and will be designed and } \\
\text { fabricated per ASME B31.1, as } \\
\text { applicable. }\end{array}$ & Y & $\begin{array}{l}\text { This requirement is provided by } \\
\text { "Procurement Specification for High } \\
\text { Pressure Hot Water System", } \\
\text { WHC-S-037 and documented in CVI } \\
\text { file } 22515 \text {. }\end{array}$ \\
\hline 49 & $\begin{array}{l}\text { 3.4.2.3 The portable high } \\
\text { pressure spray wash system } \\
\text { shall be totally enclosed } \\
\text { and/or weather proof to the } \\
\text { extent possible, except for } \\
\text { the areas open for venting } \\
\text { and connectors. }\end{array}$ & Y & $\begin{array}{l}\text { This requirement is provided by } \\
\text { "Procurement Specification for High } \\
\text { Pressure Hot Water System", } \\
\text { WHC-S-037 and documented in CVI } \\
\text { file } 22515 \text {. }\end{array}$ \\
\hline 50 & $\begin{array}{l}\text { 3.4.2.4 The spray wash } \\
\text { system shall have a relief } \\
\text { valve, unloader or vent } \\
\text { system such that there is no } \\
\text { possibility of over } \\
\text { pressurization of the system. }\end{array}$ & $\gamma$ & $\begin{array}{l}\text { This requirement is provided by } \\
\text { "Procurement Specification for High } \\
\text { Pressure Hot Water System", } \\
\text { WHC-S-037 and documented in CVI } \\
\text { file } 22515 \text {. }\end{array}$ \\
\hline
\end{tabular}




\begin{tabular}{|c|c|c|c|}
\hline $\begin{array}{l}\text { Item } \\
\text { No. }\end{array}$ & Document and Requirement & $\begin{array}{l}\text { Comply } \\
\text { Y or } N\end{array}$ & Remarks or Comments \\
\hline 51 & $\begin{array}{l}3.4 .2 .5 \text { The spray wash } \\
\text { system piping shall be } \\
\text { insulated with a moisture } \\
\text { resistant material. }\end{array}$ & $Y$ & $\begin{array}{l}\text { Spray wash system piping is not } \\
\text { insulated and does not need to be. } \\
\text { Adequate guards are in place to } \\
\text { protect personnel from high } \\
\text { temperature piping. This } \\
\text { requirement will be revised to } \\
\text { reflect the accepted condition of } \\
\text { the piping prior to its field use } \\
\text { for either project } W-151 \text { or } W-320 \text {. }\end{array}$ \\
\hline 52 & $\begin{array}{l}\text { 3.4.2.6 All piping or hoses } \\
\text { associated with the hot water } \\
\text { supply shall also have } \\
\text { sufficient protection for the } \\
\text { safety of operating } \\
\text { personnel. }\end{array}$ & $Y$ & $\begin{array}{l}\text { This requirement is provided by } \\
\text { "Procurement Specification for High } \\
\text { Pressure Hot Water System", WHC-S- } \\
037 \text { and documented in CVI file } \\
22515 \text {. Flexible hoses will also be } \\
\text { administrativlely controlled to } \\
\text { protect personnel. }\end{array}$ \\
\hline 53 & $\begin{array}{l}\text { 3.4.2.7 The system shall be } \\
\text { mounted on a highway rated } \\
\text { Department of Transportation } \\
\text { approved trailer. The } \\
\text { trailer shall be suitable for } \\
\text { travel over loose gravel. }\end{array}$ & $Y$ & $\begin{array}{l}\text { This requirement is provided by } \\
\text { "Procurement Specification for High } \\
\text { Pressure Hot Water System", WHC-S- } \\
037 \text { and documented in CVI file } \\
22515 \text {. }\end{array}$ \\
\hline 54 & $\begin{array}{l}\text { 3.4.2.8 A replaceable or } \\
\text { flushable filter shall be } \\
\text { provided for the water supply } \\
\text { with a capacity of up to } 50 \\
\text { gpm to prevent plugging of } \\
\text { the washer spray nozzles. }\end{array}$ & $Y$ & $\begin{array}{l}\text { Inlet water filter is provided. See } \\
\text { CVI file } 22515 \text {. }\end{array}$ \\
\hline 55 & $\begin{array}{l}\text { 3.4.2.9 The design shall } \\
\text { include a flexible discharge } \\
\text { supply hose capable of safely } \\
\text { handling the } 300 \text { psi hot } \\
\text { water being pumped to the } \\
\text { high pressure spray header } \\
\text { over a distance of } 200 \text { feet. }\end{array}$ & $Y$ & $\begin{array}{l}\text { This requirement is provided by } \\
\text { "Procurement Specification for High } \\
\text { Pressure Hot Water System", WHC-S- } \\
037 \text { and documented in CVI file } \\
22515 \text {. }\end{array}$ \\
\hline
\end{tabular}




\begin{tabular}{|c|c|c|c|}
\hline $\begin{array}{l}\text { Item } \\
\text { No. }\end{array}$ & Document and Requirement & $\begin{array}{l}\text { Comply } \\
Y \text { or } N\end{array}$ & Remarks or Comments \\
\hline 56 & $\begin{array}{l}3.4 .2 .10 \text { Necessary valving, } \\
\text { piping remote controls and } \\
\text { other instrumentation shall } \\
\text { be supplied as required. The } \\
\text { high pressure spray system } \\
\text { will be operated by either a } \\
\text { gasoline/diesel motor or } \\
\text { electric motor and come } \\
\text { complete with remote controls } \\
\text { and all necessary safety } \\
\text { features. }\end{array}$ & $Y$ & $\begin{array}{l}\text { This requirement is provided by } \\
\text { "Procurement Specification for High } \\
\text { Pressure Hot Water System", WHC-S- } \\
037 \text { and documented in CVI file } \\
22515 \text {. }\end{array}$ \\
\hline 57 & $\begin{array}{l}\text { 3.4.2.11 The spray system } \\
\text { shail be capable of } \\
\text { delivering between } 20 \text { and } 50 \\
\text { gpm at } 3000 \text { psig, suitable } \\
\text { for both the } 4 / 6 " \text { and the } 42 " \\
\text { spray ring assemblies. }\end{array}$ & Y & $\begin{array}{l}\text { This requirement is documented in } \\
\text { the cVI file } 22515 \text {. }\end{array}$ \\
\hline \multicolumn{4}{|c|}{ Decontamination Wash Assemblies } \\
\hline 58 & $\begin{array}{l}\text { 3.4.3.1 Hardware removed } \\
\text { from tank } 101-A Z \text { will have } \\
\text { supernate/sludge washed from } \\
\text { the external and internal } \\
\text { surfaces during the equipment } \\
\text { removal process using the } \\
\text { spray wash system. }\end{array}$ & Y & $\begin{array}{l}\text { The washing hardware is depicted on } \\
\text { drawing } \mathrm{H-2}-79256 \text { "TWRS 101-AZ } \\
\text { Washer Assembly". }\end{array}$ \\
\hline 59 & $\begin{array}{l}3.4 .3 .2 \text { Wash equipment } \\
\text { should be designed for } \\
\text { cleaning hardware, with } \\
\text { complete circumference } \\
\text { coverage, at a nominal } \\
\text { vertical removal rate of one } \\
\text { foot per minute. }\end{array}$ & Y & $\begin{array}{l}\text { The washing hardware is depicted on } \\
\text { drawing H-2-79256 "TWRS 101-AZ } \\
\text { Washer Assembly". }\end{array}$ \\
\hline
\end{tabular}




\begin{tabular}{|c|c|c|c|}
\hline $\begin{array}{l}\text { Item } \\
\text { No. }\end{array}$ & Document and Requirement & $\begin{array}{l}\text { Comply } \\
Y \text { or } N\end{array}$ & Remarks or Comments \\
\hline 60 & $\begin{array}{l}\text { 3.4.3.3 Nozzles with a flat } \\
\text { spray configuration and an } \\
\text { operating pressure of } 3000 \\
\text { psi shall be used in the } \\
\text { washer assembly. Nozzles } \\
\text { shall be orientated such that } \\
\text { both top and bottom sides of } \\
\text { protrusions on the removed } \\
\text { components exterior are } \\
\text { thoroughly rinsed, in } \\
\text { addition to the vertical } \\
\text { surfaces. }\end{array}$ & $Y$ & $\begin{array}{l}\text { The washing hardware is depicted on } \\
\text { drawing } H-2-79256 \text { "TWRS 101-AZ } \\
\text { Washer Assembly". }\end{array}$ \\
\hline 61 & $\begin{array}{l}3.4 .3 .4 \text { The } 4 / 6^{11} \text { spray ring } \\
\text { shail be sized for } 20-25 \mathrm{gpm} \\
\text { flow rate at } 3000 \mathrm{psig.} \mathrm{The} \\
42 " \text { spray ring shall be sized } \\
\text { for } 40-50 \mathrm{gpm} \text { flow rate at } \\
3000 \text { psig. }\end{array}$ & $Y$ & $\begin{array}{l}\text { The washing hardware is depicted on } \\
\text { drawing H-2-79256 "TWRS 101-AZ } \\
\text { Washer Assembly". }\end{array}$ \\
\hline
\end{tabular}




\begin{tabular}{|c|c|c|c|}
\hline $\begin{array}{l}\text { Item } \\
\text { No. }\end{array}$ & Document and Requirement & $\begin{array}{l}\text { Comply } \\
Y \text { or } N\end{array}$ & Remarks or Comments \\
\hline 62 & $\begin{array}{l}\text { 3.4.5.1 Trailer } \\
\text { a. Provide environmentally } \\
\text { controlled trailer housing } \\
\text { instrumentation, electrical \& } \\
\text { control equipment, operators, } \\
\text { monitors, vcRs, displays and } \\
\text { recording equipment. Trailer } \\
\text { shall house Instrumentation } \\
\text { and Control (I\&C) equipment } \\
\text { for the flexible receiver, } \\
\text { washer, and radiation } \\
\text { monitoring. } \\
\text { b. All suitable I\&C } \\
\text { equipment shall be installed } \\
\text { in } 19 \text { inch racks to the } \\
\text { extent possible. } \\
\text { c. All cables and wiring } \\
\text { inside of the trailer shall } \\
\text { conform to the requirements } \\
\text { NFPA-70. } \\
\text { d. Trailer shall have smoke } \\
\text { detection with audible alarm. } \\
\text { e. Maximum power to the } \\
\text { trailer shall be limited to } \\
440 \text { vaC, } 3 \text { phase. } \\
\text { f. Trailer shall have } \\
\text { personnel exits at opposite } \\
\text { ends of the trailer which } \\
\text { open from the inside. Rear } \\
\text { cargo doors do not count as } \\
\text { exits. }\end{array}$ & $\begin{array}{l}Y \\
Y\end{array}$ & $\begin{array}{l}\text { The Flexible Receiver Control } \\
\text { Trailer is depicted on drawing } \\
\text { H-2-78935, "W151 - TWRS Trailer } \\
\text { Assembly". }\end{array}$ \\
\hline
\end{tabular}




\begin{tabular}{|c|c|c|c|}
\hline $\begin{array}{l}\text { Item } \\
\text { No. }\end{array}$ & Document and Requirement & $\begin{array}{l}\text { Comply. } \\
Y \text { or } N\end{array}$ & Remarks or Comments \\
\hline & $\begin{array}{l}\text { g. Environmental controls } \\
\text { shall consist of the } \\
\text { following: } \\
\text { 1. Cooling capacity to } \\
\text { achieve and maintain a } 70^{\circ} \mathrm{F} \\
\text { condition with an outside } \\
\text { ambient temperature of } 115^{\circ} \mathrm{F} \text {, } \\
\text { full solar insulation, and } \\
\text { heat loads from the I\&C } \\
\text { equipment. } \\
\text { 2. Heating capacity to } \\
\text { achieve and maintain a } 70^{\circ} \mathrm{F} \\
\text { with an ambient temperature } \\
\text { of } 10^{\circ} \mathrm{F} \text {. } \\
\text { 3. Controls shall be } \\
\text { designed for local operator } \\
\text { control and be user friendly. } \\
\text { Ergonomics shall be used in } \\
\text { the lay-out of controls and } \\
\text { consoles. } \\
4 . \text { Heating/cooling unit } \\
\text { can be one combination unit. } \\
5 \text { Unit shall incorporate } \\
\text { an integral fan for air } \\
\text { circulation, and provide for } \\
\text { outside air exchanges. } \\
6 \text { The system shall also } \\
\text { be designed based on other } \\
\text { ambient conditions specified } \\
\text { in Standard Design Criteria } \\
\text { (SDC) } 5.1 \text {. }\end{array}$ & $\begin{array}{l}Y \\
Y\end{array}$ & \\
\hline
\end{tabular}




\begin{tabular}{|c|c|c|c|}
\hline $\begin{array}{l}\text { Item } \\
\text { No. }\end{array}$ & Document and Requirement & $\begin{array}{l}\text { Comply } \\
Y \text { or } N\end{array}$ & Remarks or Comments \\
\hline 63 & $\begin{array}{l}\text { 3.4.5.2 Flexible Receiver } \\
\text { Control Console (FRCC) } \\
\text { a. The FRCC shall control } \\
\text { the operation of the Flexible } \\
\text { Receiver, including the } \\
\text { thermocouple liquid removal } \\
\text { tool, in a manually actuated } \\
\text { sequence (controller forces } \\
\text { operator to a fixed sequence) } \\
\text { with manual emergency } \\
\text { override controls available } \\
\text { to secure the operation in a } \\
\text { safe configuration. } \\
\text { b. The sequence, interlocks } \\
\text { and indicating lights shall } \\
\text { be provided for equipment } \\
\text { operation. } \\
\text { c. FRCC shall be located in } \\
\text { the trailer described in } \\
\text { 3.4.5.1. } \\
\text { d. Parameters shall be } \\
\text { displayed in engineering } \\
\text { units. } \\
\text { e. Three ccTV monitors and } \\
\text { cameras shall be provided to } \\
\text { monitor field operations. } \\
\text { f. Operators shall be able } \\
\text { to, through a front panel } \\
\text { select or on a multiplexer, } \\
\text { view any camera on any } \\
\text { monitor. }\end{array}$ & $Y$ & $\begin{array}{l}\text { To be demonstrated in Qualification } \\
\text { Testing. }\end{array}$ \\
\hline
\end{tabular}




\begin{tabular}{|c|c|c|c|}
\hline $\begin{array}{l}\text { Item } \\
\text { No. }\end{array}$ & Document and Requirement & $\begin{array}{l}\text { Comply } \\
Y \text { or } N\end{array}$ & Remarks or Comments \\
\hline & $\begin{array}{l}\text { g. The camera used to view } \\
\text { the retrieved material in the } \\
\text { gamma assay region shall } \\
\text { include superimposed height } \\
\text { and/or time indication on } \\
\text { screen for correlation with } \\
\text { gamma energy analysis } \\
\text { results. The gamma assay } \\
\text { system will store data by } \\
\text { time stamp as part of its } \\
\text { operation. The subject } \\
\text { camera data will be actively } \\
\text { recorded. }\end{array}$ & $Y$ & \\
\hline 64 & $\begin{array}{l}\text { 3.4.5.3 Wash Assembly } \\
\text { Control Console (WACC) } \\
\text { a. The WACC shall control } \\
\text { the operation of the spray } \\
\text { wash system in a manually } \\
\text { actuated sequence. } \\
\text { b. The sequence, interlocks } \\
\text { and indicating lights shall } \\
\text { be provided on the control } \\
\text { panel for the system } \\
\text { operator. (May be shared } \\
\text { with FRCC.) } \\
\text { c. WACC is located in the } \\
\text { trailer (3.4.5.1). } \\
\text { d. Parameters shall be } \\
\text { displayed in engineering } \\
\text { units. } \\
\text { e. Controls and } \\
\text { instrumentation shall be } \\
\text { included in the console } \\
\text { operating panel. (See Figure } \\
\text { 10 for spray system } \\
\text { configuration.) }\end{array}$ & $\begin{array}{l}Y \\
Y \\
Y \\
Y \\
Y \\
Y\end{array}$ & $\begin{array}{l}\text { To be demonstrated in Qualification } \\
\text { Testing. }\end{array}$ \\
\hline
\end{tabular}




\begin{tabular}{|c|c|c|c|}
\hline $\begin{array}{l}\text { Item } \\
\text { No. }\end{array}$ & Document and Requirement & $\begin{array}{l}\text { Comply } \\
\text { Y or } N\end{array}$ & Remarks or Comments \\
\hline 65 & $\begin{array}{l}\text { 3.4.5.4 Radiation Monitoring } \\
\text { Control Console } \\
\text { Radiation monitoring controls } \\
\text { (computer data acquisition) } \\
\text { and readout shall be } \\
\text { installed in } 19 " \text { racks (to } \\
\text { the extent practical) with } \\
\text { other control equipment in } \\
\text { the AZ tank farm control } \\
\text { room. }\end{array}$ & $Y$ & $\begin{array}{l}\text { See drawing H-2-78931 "TWRS Control } \\
\text { Console". }\end{array}$ \\
\hline 66 & $\begin{array}{l}\text { 3.4.5.5 Electrical System } \\
\text { The electrical system in } \\
\text { a. The trailer shall convert the } \\
\text { supplied } 440 \text { VAC, } 3 \text { phase as } \\
\text { necessary for use by the } \\
\text { instrumentation, electrical \& } \\
\text { control equipment, monitors, } \\
\text { displays and recording } \\
\text { equipment, lighting and } \\
\text { environmental equipment. } \\
\text { b. The installation shall be } \\
\text { per the latest edition of the } \\
\text { National Electric Code (NFPA } \\
\text { 70). }\end{array}$ & $Y$ & $\begin{array}{l}\text { The Flexible Receiver Control } \\
\text { Trailer is depicted on Drawing H- } \\
\text { 2-78935, "W151 - TWRS Trailer } \\
\text { Assembly". }\end{array}$ \\
\hline
\end{tabular}




\section{PART II - DESIGN VERIFICATION BY OPERATIONAL TESTING}

\subsection{TEST ITEM IDENTIFICATION}

The Flexible Receiver (FR) is a remotely operated device to remove equipment contaminated with radioactive and hazardous waste from burjed tanks or below-ground installations with minimal exposure to the operating personnel and no release of contamination to the environment. This equipment will be attached to a pipe flange or plate at the top of the proposed removed equipment. The Flexible Receiver will wash the equipment off as it is being removed, check for the amount of radiation on the equipment, insert the equipment in a fabricated bag, and seal the equipment in this bag for disposal or storage.

All of the controls of the equipment are located in a trailer with interlocks on each of the control switches so that accidental operation of equipment can't happen without the prior proper sequence of operations being performed.

Figure 1 shows a breakdown of the equipment by systems. There are two types of receivers; one that can remove equipment from a 42 " diameter riser (see Figure 2) and this is referred to as the 42", and the second one can remove equipment from 4" and 6" diameter risers (see Figure 3) and is referred to as the 4"-6" Flexible Receiver. The Flexible Receiver systems are

described on drawings $\mathrm{H}-2-79336$ for the $4^{\prime \prime}-6^{\prime \prime}$ Flexible Receiver and H-2-79342 for the 42" Flexible Receiver.

NOTE: The GAMMA ASSAY SYSTEM will not be tested by this document but has been tested per. WHC-SD-W151-ATP-001.

\subsection{FLEXIBLE RECEIVER SYSTEMS}

FLEXIBLE RECCEIVER BAG AND CARTRIDGE ASSY

FLEXIBLE RECEIVER TOP ASSY

\section{CCTV CAMERAS}

GAMMA ASSAY SYSTEM AND SPOOL ASSY
- Frame and special bag that equipment is pulled up and into.

- Assembly that closes the bottom of the bag, cinches the wire rope cables, cuts the cables and cuts the bag between the sealed sections of the bag.

- Used to remotely

- Monitors radiation of equipment being pulled out, provides access to the inside of the spool assembly and is the mounting for internal cameras. 
- zna sem zeyz 6eq Kaeutad ayq to

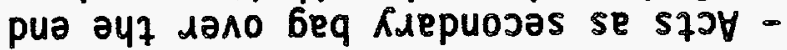


Figure 1. Flexible Receiver Systens

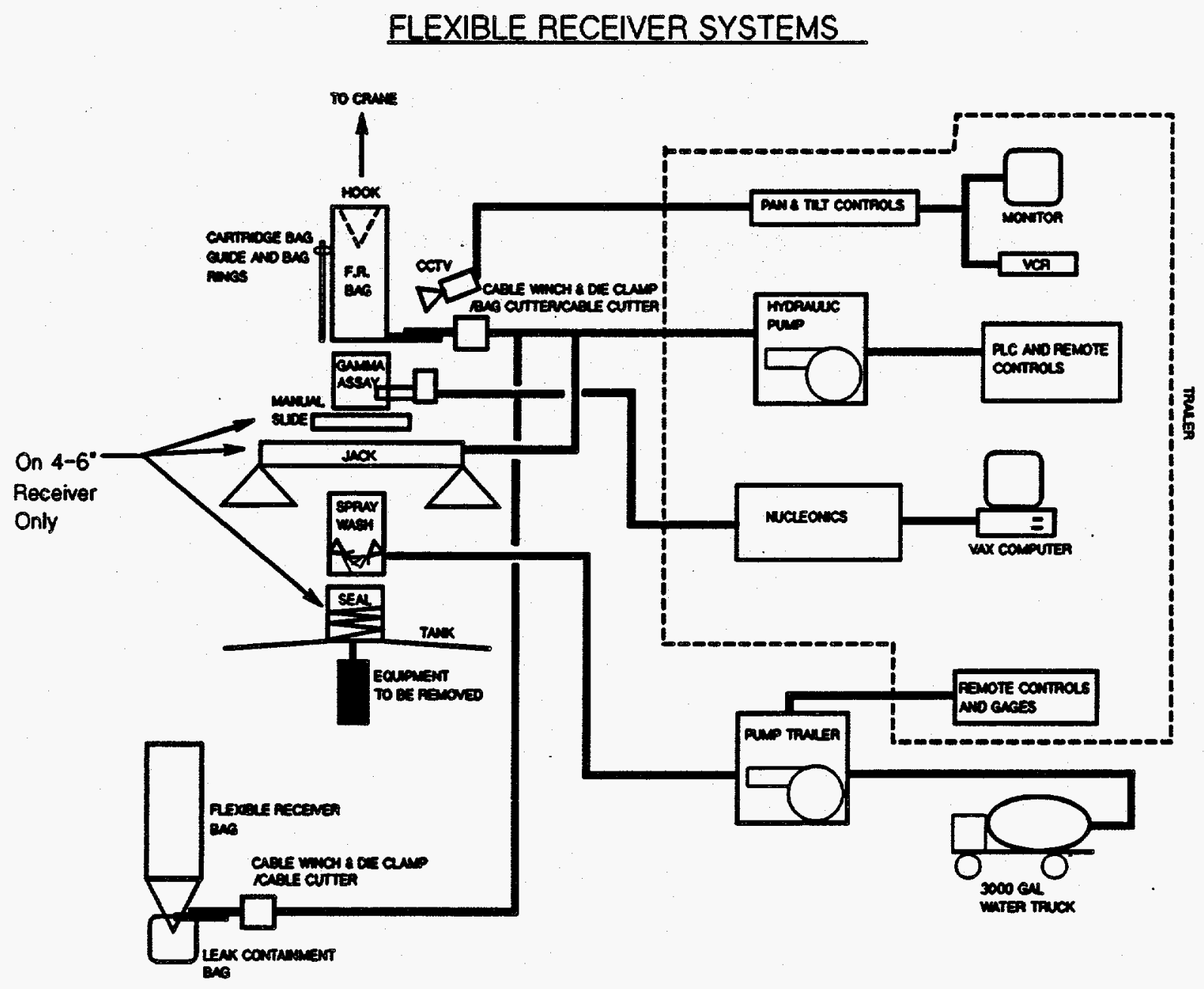


Figure 2. Typical $42^{*}$ Flexible Receiver Located On A Tank

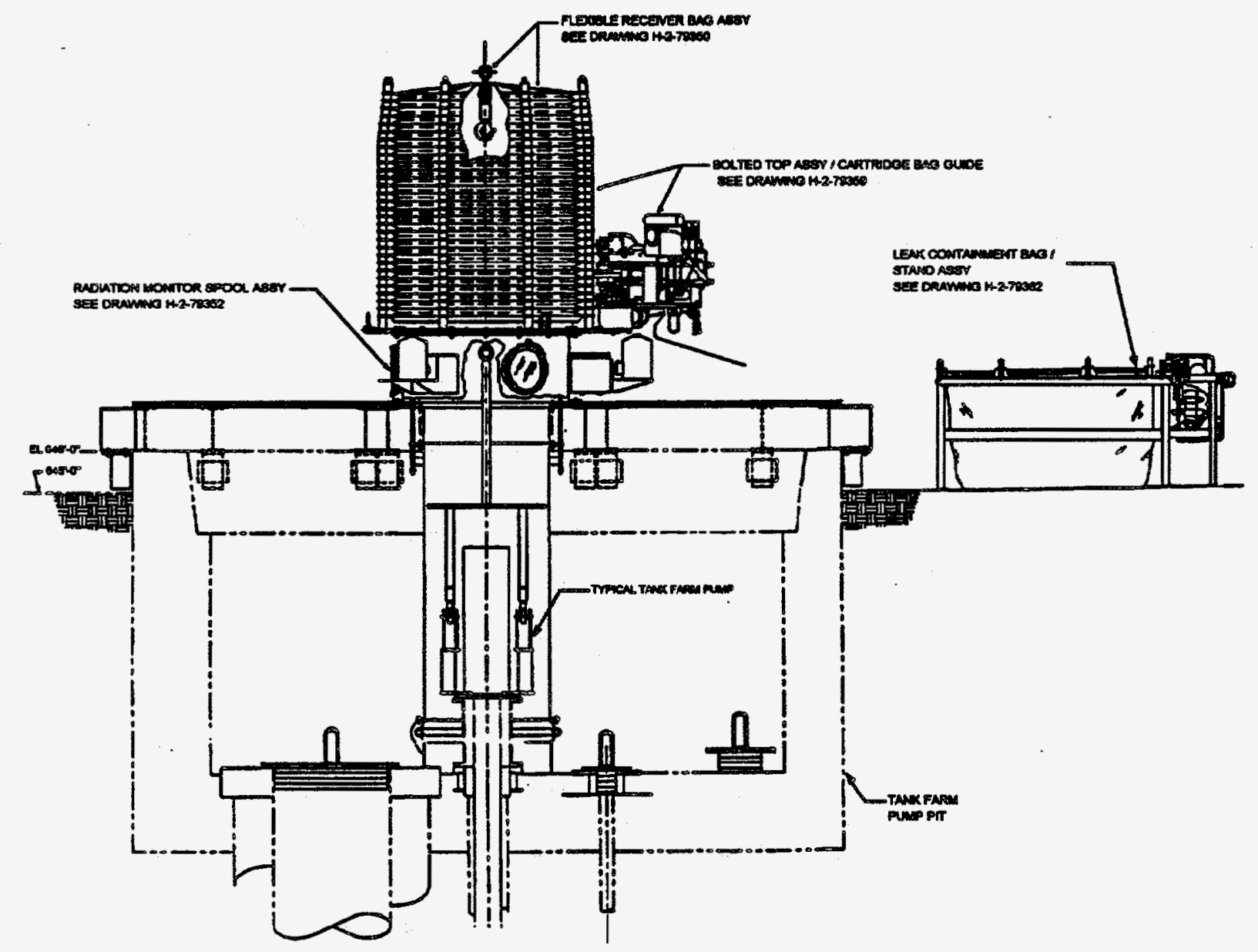


Figure 3. Typical 4"-6" Flexible Receiver Located On A Tank

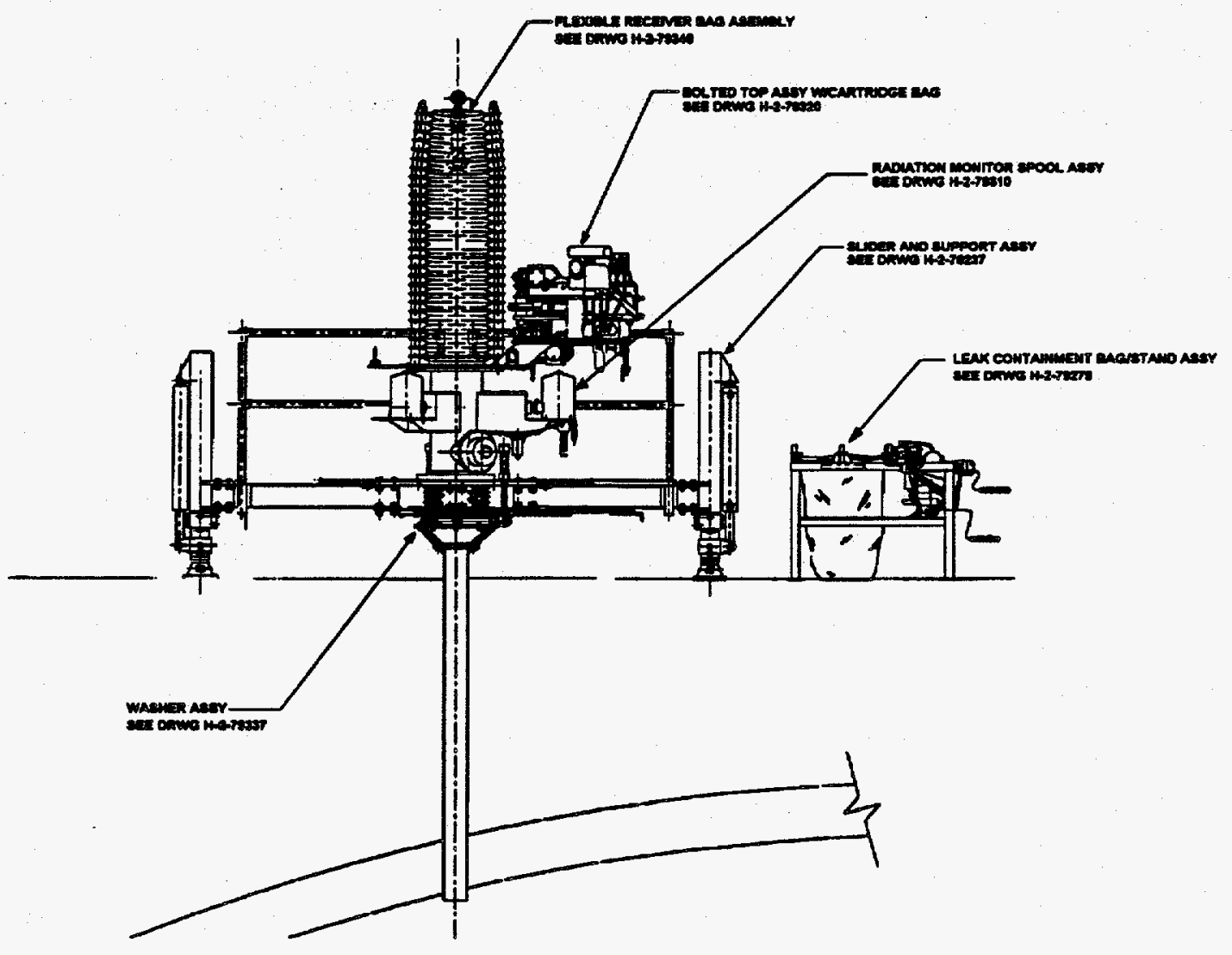




\subsection{GENERAL DESCRIPTION}

\subsection{TEST OBJECTIVES}

The objective of this test is to qualify the design of the $42^{\prime \prime}$ and 4 " -6 " Flexible Receiver systems for field use by demonstrating environmentally safe removal of a Tank Farm pump mock-up from a Tank Farm riser mock-up. Testing will also demonstrate the performance of supporting equipment.

The Flexible Receiver and the Secondary Bagging equipment shall be tested to verify successful operation of the equipment to the following criteria:

a. The Flexible Receiver can be placed on a riser and connections made to the supporting equipment.

b. The Flexible Receiver bag can accept equipment and be successfully sealed.

c. The Secondary Bagging System encases the seal of the primary Flexible Receiver bag.

d. The flexible bag(s) do not tear and maintain integrity during the entire test.

e. The FR control system operates in the fail safe forced sequence mode.

f. The FR control system will operate in the manual override mode (out of sequence operations).

g. The CCTV Video system monitors and records the removal of the test item.

h. The spray wash system operates without leaks and effectively provides coverage (4"-6" on 1 y).

i. The item being removed can be reinserted to a depth of 8 feet and the bag reinstalled onto the vertical bag supports.

j. The system prohibits momentary mechanical fluctuations due to the application of system power, including power interruptions.

\subsection{TEST CONDITION LIMITS}

\subsection{OPERATIONAL LIMITS}

No unique or unusual industrial, radiological, chemical, or critical safety hazards are involved with performance of this test. 
Testing will be stopped due to any safety concern, equipment failure, or at the discretion of the Test Director. Resumption of testing will continue when the concerns have been addressed and/or repairs have been completed to the satisfaction of the Test Director.

\subsection{ENVIRONMENTAL LIMITS}

The crane pulling operation beginning with step 8.3.2.11 shall NOT begin if the wind velocity exceeds $10 \mathrm{MPH}$. If the pulling operation has begun and the weather changes for the worse, testing shall be stopped and the test equipment secured so that no damage will be incurred.

\subsection{FACILITIES, EQUIPNENT, AND MATERIALS}

\subsection{TEST FACILITY}

Testing will be performed at the Cold Test Facility, located west of Route 4 on Route 11A between the 200 East and 200 West Areas. The Cold Test Facility consists of a 10'-0" inside square vault, 11'-0" deep. Extending below the bottom of the vault floor is a 6'-0" diameter caisson 53'-0" deep.

As an option portions of this test may be performed at the Equipment Testing Laboratory (305 Bldg), or other suitable facility.

\subsection{EQUIPMENT}

- The on-site modified 110 Ton "GROVE" crane or equal.

- A vacuum system that will simulate the negative pressure within the waste tank. Vacuum pressure is equal to or greater then 0.25 inches of water but will not exceed 2 inches of water during operation.

- Electrical power for the Flexible Receiver control trailer and pump truck $480 \mathrm{~V} 3 \mathrm{PH} 60 \mathrm{HZ}$ and 200 Amps for control trailer and 200 Amps for the HPS pump trailer.

- $\quad 3000$ gallon water truck filled with water to $150-175^{\circ} \mathrm{F}$

- The high pressure spray trailer

- The 42" or 4"-6" Flexible Receiver

- The 42 " or 4"-6" Secondary Bagger

- A 70 foot long Flexible Receiver bag for the 42" or 4"-6" FR

- A 42" secondary bag for the 42 " or $4 "-6$ " FR

- A simulated process pump and thermocouple 
- Control trailer with hydraulic pump, control racks, video systems, etc

- Emergency pole for placing rings on FR poles when lowering the receiver bag.

- Stop watch

- Spare components, such as test bags, cabling, and cable sleeves that will be expended during testing.

- Safety equipment: hard hat, leather gloves, safety glasses, steel toed shoes

- Replacement bulbs for control panel lights.

- 3 VHS tapes (minimum)

- PLC accessories

\subsection{SAFETY}

NOTE: THE INFORMATION IN THIS SECTION SHALL BE TOLD TO ALL PERSONNEL IN OR AROUND THE TEST AREA BEFORE TESTING BEGINS. SAFETY IS THE RESPONSIBILITY OF ALL INDIVIDUALS. ALL CONCERNS SHOULD BE DIRECTED TO THE TEST DIRECTOR OR APPOINTEE.

Hazards associated with the job are found in the Preliminary Safety Evaluation (WHC-SD-WM-PSE-010) with the exception of the radiological hazards which will not apply to this test. Potential hazards are: over head objects (crane), tripping (wires and hoses on the ground), pinch points, and exposed 3000 psig high pressure $150^{\circ} \mathrm{F}$ hot water and hydraulic lines. All personnel within the crane operating zone will wear safety glasses, a hard hat, and steel toed shoes. Individuals working on or near the high pressure pump trailer/or its hoses are advised to wear hearing protection, a hard hat, safety glasses, and leather gloves when operating.

The test area will be kept free from nonessential personnel as directed by the Test Director. Individuals shall perform their assigned tasks in a safe manner so as to protect themselves and others from hazards and prevent damage to the property and the environment. The Test Director shall assure the safety of activities within their areas to prevent injury, property damage, or interruption of operation.

Crane operations shall be in accordance with the "Hanford Site Hoisting and Rigging Manual", (DOE-RL-92-36).

\subsection{EXCEPTIONS}


Exceptions to the test results will be sequentially numbered, recorded, and approved on individual Exception forms. If changes to the procedure are required during testing those changes will also be documented on an Exception Form. All exception forms will have written approval by the Test Director and Quality Assurance prior to the conclusion of testing. Whenever possible, exceptions will be approved at the time they are prepared. If required personnel are not available for approval at the time the exception is prepared then testing will be allowed to continue. Exception approval to continue testing may be written, verbal, or per telecon.

\subsection{PERSONNEL REQUIREMENTS}

\subsection{GENERAL}

Each organization participating in this test will designate personnel to assume the responsibilities and duties as defined herein for their respective roles. The designated personnel shall become familiar with this procedure and systems involved to the extent that they can perform their assigned duties.

\subsection{TEST DIRECTOR}

- Coordinates and directs testing.

- Acts as liaison between the participants in testing.

- Distributes the testing schedule within one week before start of testing.

- Schedules and conducts a pretest meeting with test participants before start of testing when necessary.

- Notifies the persons performing and witnessing the test 2 days before the start of testing.

- Schedules an informal test (dry run) when necessary.

- Notifies concerned parties when a change is made in the testing schedule.

- Takes necessary steps to clear exceptions to the test.

- Confirms that inspection of the system to be tested has been completed.

- Stops any test which, in the judgement of the director, may cause damage to the system or result in an Unsafe Condition.

- After verifying there is no adverse impact, may alter the sequence in which system or subsystems are tested, but not the sequence of 
- sә7ep uo!̨edidxə

uo!fedq! Les pue sdəqunu uo!zes!f!quəp! quaundqsu! $75 \partial q$ sploכəy

- $64 \div+7527$

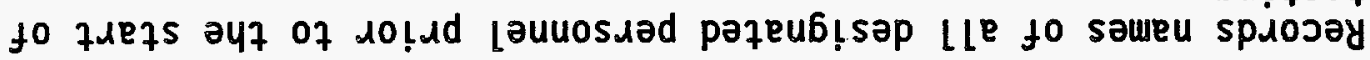

8за80э38 $\varpi^{\circ} L$

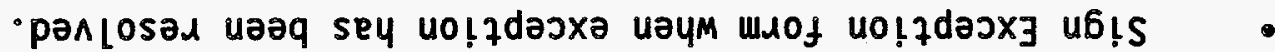

- pawnofuzd

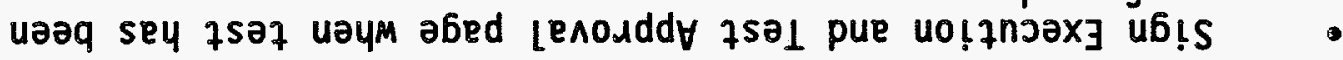

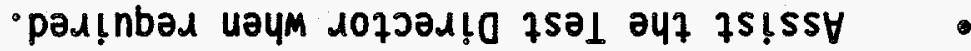

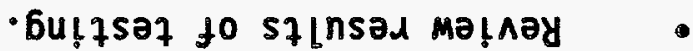

- suo!ftpuos unef Xuez Lenzas dəpun

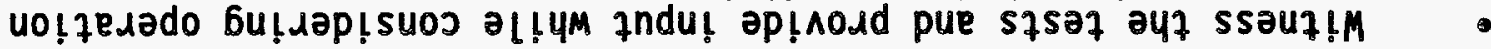

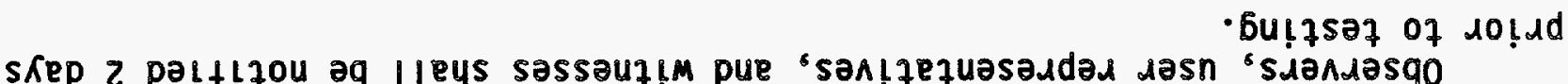

(suo!fez!uebio Gu!qed!ว!qued kq pop!nodd)

SISSJNLIM $\varepsilon^{\circ} \mathrm{L}$

- qọ to notgalduos ge

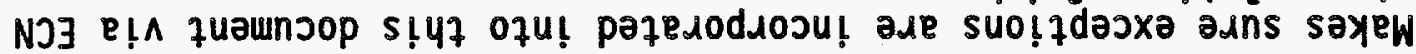

'quodad qsaz leu!f ayz dof sadnqeub!s lenoddde pad!nbas su!eqqo

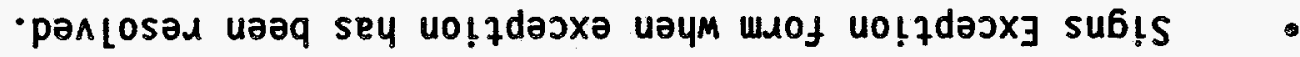

- pawnojuad

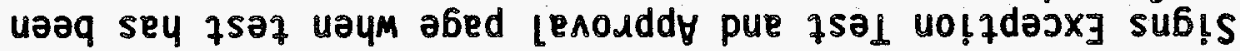

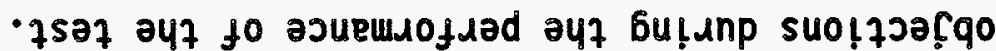

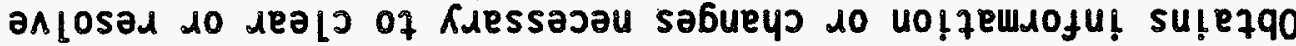

-suo!fdasxa pue 'sa!juedalas!p 'eqep papıosad sma!nay -

- saz!s!nbacadd

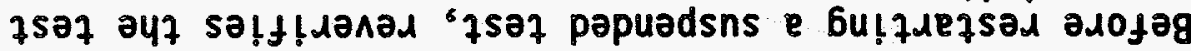

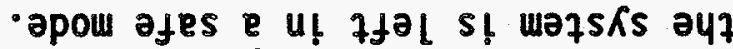

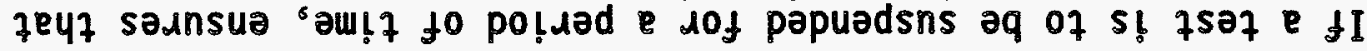

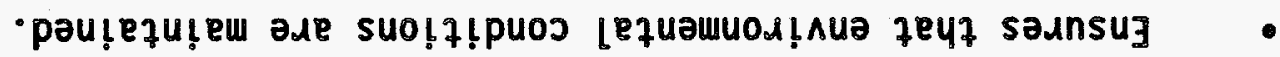

-qsaz yวea u! sdazs

$\varepsilon \varepsilon$ obed

$\rightarrow 66$ I 'ZT dәquәวә0

Z ^әУ [00-SII-OZEM-OS-JHM 
- Observes tests and records test data.

- Signs Execution and Test Approval page.

- Initials and dates test steps as they are completed. On data sheets where there is not room for both the initial and date, the data may be added at the bottom of the column.

- Records exceptions on the Exception form.

- Signs Exception form when exception has been resolved.

- Notifies the Test Director at the time an objection is made.

- After the test is completed, assigns alpha numeric page numbers to added data sheets and Exception forms. Records page numbers in the Table of Contents.

\subsection{TEST OPERATOR}

- Performs test under direction of the Test Director.

- Provides labor, equipment, and test instruments required for performing tests.

- Confirms that all equipment required for performing test will be available at the start of testing.

- Signs the Execution and Test Approval page.

\subsection{QUALITY ASSURANCE WITNESS}

- Witnesses test steps are performed.

- Signs and approves test and exceptions.

\subsection{COG ENGINEER}

- Main Technical consultant on equipment

\subsection{TEST PROCEDURE}

NOTE: This procedure applies to the 42" flexible receiver only. This procedure has been performed per Revision 1 (see Appendix A for signed off steps and exceptions). The procedure for testing the 4"6" flexible receiver is located in Section 11.0 .

\subsection{GENERAL SYSTEM REQUIREMENTS}


Cables and pipes are all connected per the FR drawings. The system permissive includes electrical verification that the control cable(s) have been installed.

A manual operation (i.e. operator actuate a switch) is required prior to starting or continuing operation after power is applied to the controller.

Operator must manuali.y push, twist, or turn button(s) to control the sequence for the FR assembly and Secondary Bagger equipment. The control sequence for the Flexible Receiver assembly and Secondary Bagger equipment is implemented by a manually actuated, forced sequence of events; i.e. the operator manually pushes the button for the next step in the sequence while the controller ignores any input from the operator that is out of sequence.

Operator may use a "manual control" key operated switch to by-pass the normal system interlocks and permissive (under the procedural permission of the Test Director or assigned person-in-charge) in order to deal with an unusual situation.

\subsection{TEST CONDITIONS}

The following items shall be performed prior to other steps of this procedure.

\section{Initial/Date}

\subsubsection{Install 42" flexible receiver on CTF.}

8.2.2 Install primary $70 \mathrm{ft}$ bag and cables on 42 " FR per drawing H-2-79359.

8.2.3 Install secondary bag and cable on leak container bag assembly.

8.2.4 Flexible receiver assembly has been properly attached to the Cold Test Facility per $\mathrm{H}-2-79218$ and/or $\mathrm{H}-2-79219$ and/or $\mathrm{H}-$ 2-79220 and/or $\mathrm{H}-2-79221$ and support equipment (secondary bagger, control trailer, and high pressure water pump trailer and water truck (if applicable). Ensure hook swivel is attached to the pump lifting device. Note attachment of FR may require the use of the hydraulic jacks (ONLY on 4 " -6 " FR) which would require uperation of the hydraulic pump in the control trailer (use steps in 8.3 OPERATIONAL SEQUENCE, 8.3.1 START UP SEQUENCE, to operate pump).

8.2.5 All systems being tested have their hoses, piping, and electrical instrumentation and power properly connected per FR drawings.

8.2.6 Power is OFF to components of systems being tested. 
- Switch DS1 "MAIN POWER" is off.

- Switch DS2 "HYDRAULIC PWR UNIT" is off.

- Switch DS3 "T1 TRANSFORMER" is off.

- Switch DS4 "HYD POWER UNIT" is off.

8.2.7 A11 test instruments have a valid calibration stamp attached.

8.2.8 Personnel responsible for directing and witnessing the performance of the tests described in this QTP have read and understand the operation of the equipment to be tested.

8.2.9 All personnel involved in, or witnessing, testing have met the safety requirements 1 isted in section 5.0 .

\subsection{OPERATIONAL SEQUENCE}

The following describes the sequence of events the Flexible Receiver Programmable Logic Controller (PLC) performs in conjunction with the operator(s) actions, and Secondary Bagger equipment. The control logic has 3 major parts: 1) Start up and initial conditions, 2) Operations performed by the Flexible Receiver, and 3) Operations performed by the Secondary Bagger.

The sequence of events are as follows: 1) Start up of equipment; 2) pull equipment out; 3) pull bag tight with cable; 4) clamp cable; 5) cut bag; 6) cut cable; 7) move bagged equipment to secondary bagger; 8) pull secondary bag tight with cable; 9) clamp cable; 10) cut cable.

If power is unexpectedly lost, the system shuts down and stops as is. Upon restoration of power, the "RESET" button is pressed and the system resumes operation at the step it was last performing before loss of power. This will be tested during the bagging operation.

\subsubsection{Start Up Sequence}

WARNING: Turning the HYDRAULIC POWER UNIT key switch, or the START SEQUENCE key switch to OFF, or loss of cable continuity at anytime will deenergize the master system permissive (internal coil 202). The controller will not permit any further actions until corrected.

The following is to be performed on the control panels in the trailer.

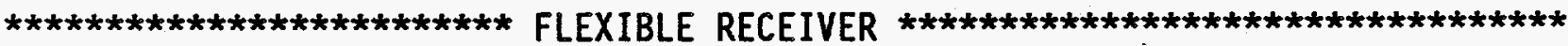
8.3.1.1 Section 8.2 has been completed. 8.3.1.2 Verify all switches located on the Flexible Receiver and High Pressure Spray control panels are in the OFF 


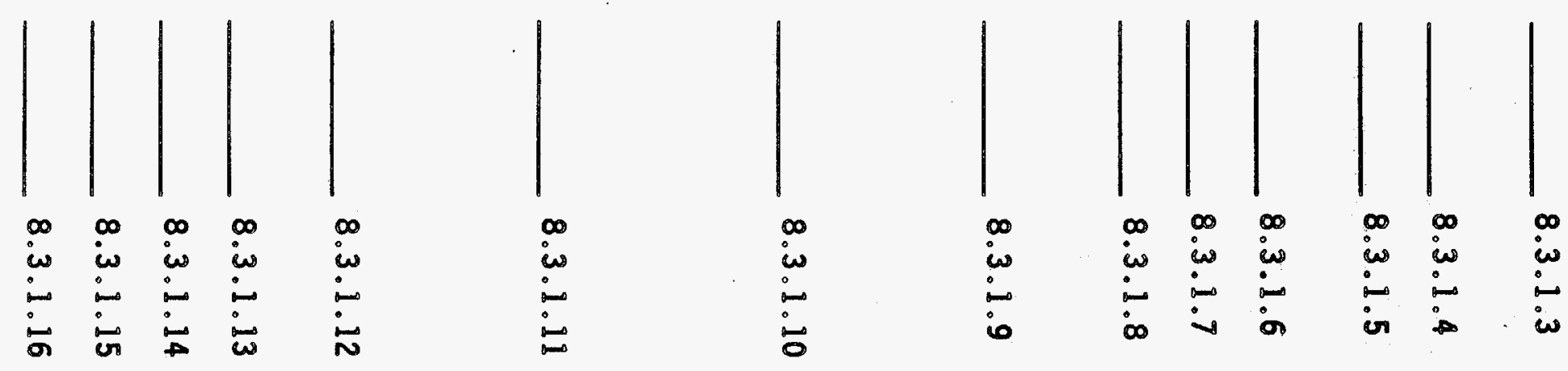

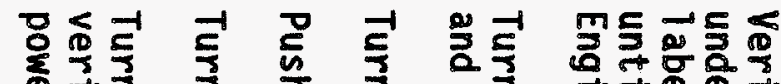

要边

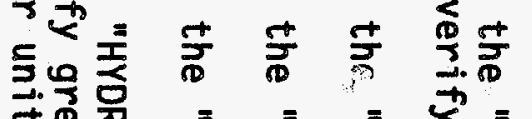

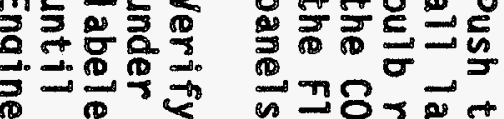

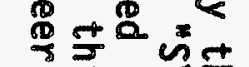

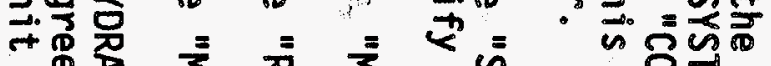

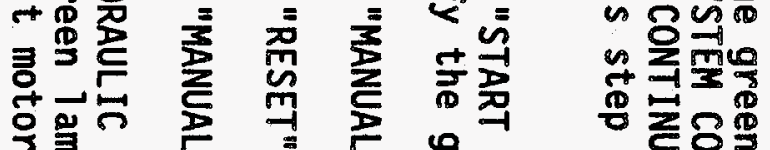

兽觜

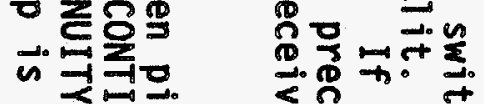

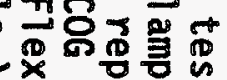

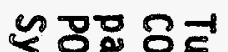

กี่

可행

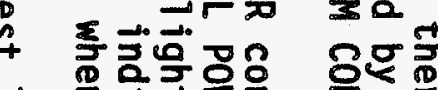

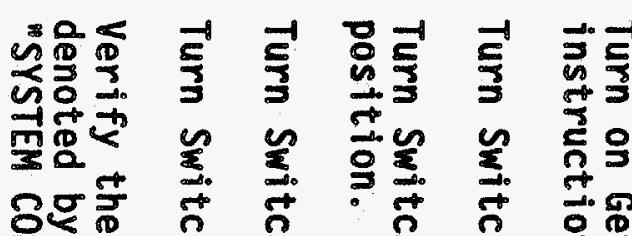

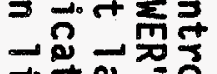

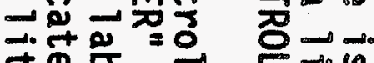

गิกำ

$\overrightarrow{4} \vec{\exists}$ 흒

눙

융

帝

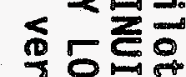

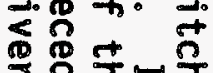

ב. 品再

วัँे

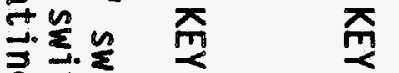

$\rightarrow \stackrel{1}{\prime \prime}$

的的要

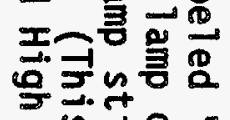

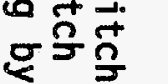

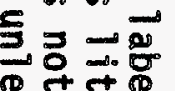

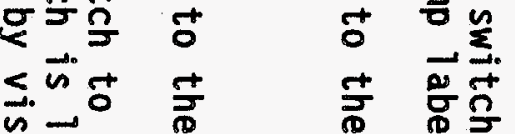

为要

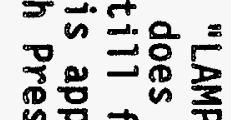

a $\vec{F} \overrightarrow{a^{\circ}}$

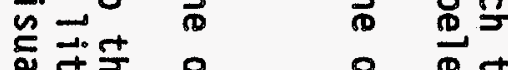

ᄀैं

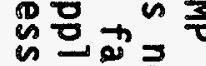

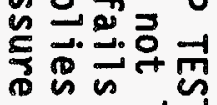

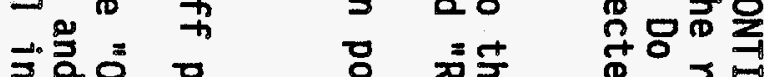

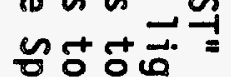

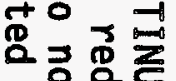

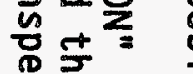

号宁品

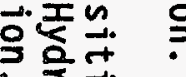

롱

तี ั้ำ

प+口.

砵可言

유ㅇㅠㅠ융ㅇㅇ

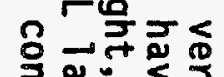

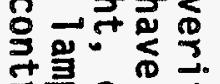

जั:

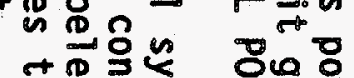

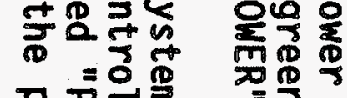

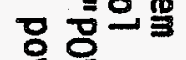

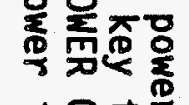

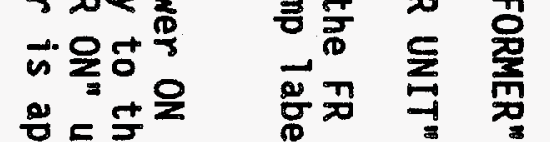

$=3$

풀

몽응

象䂞 虫

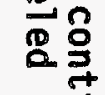

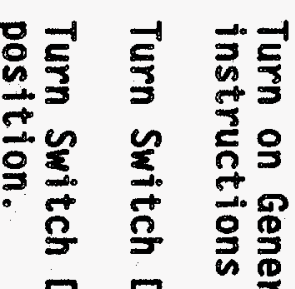

용

员怘 운

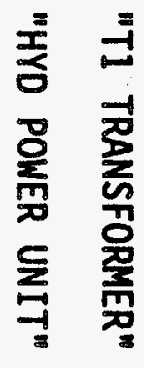

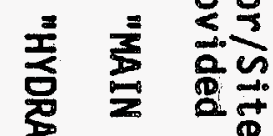

密 $\sigma^{\circ} \circ$

药

软苛

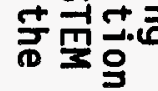

突吕

$=$ 윢츄 율

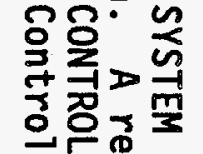

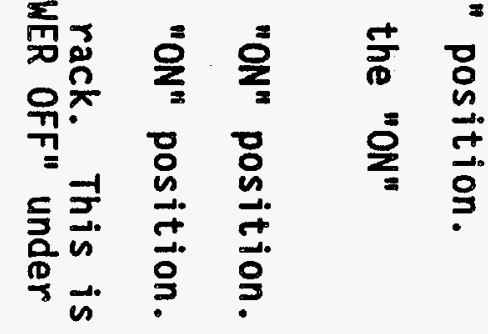

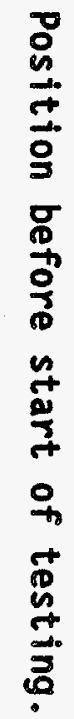

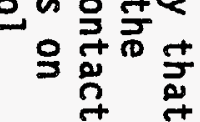

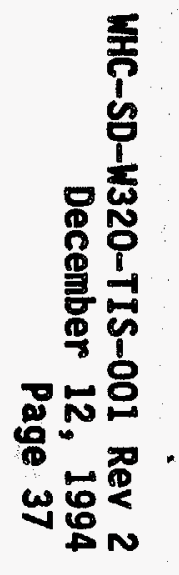




\subsubsection{Verify "SYSTEM HYDRAULIC PRESSURE" panel meter is reading} $0 \pm 100$ (psig).

8.3.1.18 Verify pressure gages on hydraulic pump in trailer, cable cutter, bag cutter, cable tie clamp, winch motors, jacks on the receiver unit, bellows separator (only on the 4"-

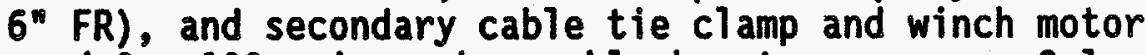
read $0 \pm 100$ psig or has a blank meter screen. Only the meters associated with a function that is currently being used will show a pressure reading. If the meter reads 100 or greater before the starting that sequence, contact COG before proceeding.

8.3.1.19 Verify hydraulic connections are not leaking. If piping requires tightening, then turn "HYDRAULIC PWR UNIT" switch to the "OFF" position and resolve leak. Restart system by repeating steps 8.3.1.9? - 8.3.1.12.?

8.3.1.20 TUrn "HYDRAULIC PWR UNIT" switch to the "OFF" position.

8.3.1.21 Remove the crane hook from the eyebolt of the FR bag. Raise the crane hook at a constant rate provided by the Test Director. Record the rate displayed at the FR Control Panel "CRANE HOIST ELEVATION RATE (feet per minute)" meter and the rate displayed at the crane. Verify that the displayed values are consistent.

Rate at Crane: $\mathrm{ft} / \mathrm{min}$

Rate at FR Trailer: $\mathrm{ft} / \mathrm{min}$

\section{CAMERA MONITORING}

8.3.1.22 Under each monitor, ensure none of the buttons 1-8 are selected by being lit or by being depressed.

8.3.1.23 Under monitor \#3, flip the "POWER" switches on camera control units 1 through 5 to the "ON" position and verify the green lights 1 abeled "POWER" is 1 it for each controller.

8.3.1.24 Turn on VCR's 1 through 3 by pressing "POWER" button and ensure the "POWER" light for each is on.

8.3.1.25 Turn on the "SONY" Video monitors by pushing in the "POWER" button and verify that the green light for each is 1 it.

8.3.1.26 Turn on the Pan Tilt power. 
8.3.1.27 Select camera's 1 through 3 for monitors 1 through 3 by pushing the appropriate button under each monitor.

8.3.1.28 Move the switch from the "OFF" position to "VERTICAL" position on the time/date generators $1-3$ and verify time and date are displayed on each monitor.

8.3.1.29 Set the time and date according to the manufacturers manual if date/time isn't correct.

\section{NOTE: ON CAMERAS}

Adjustments to picture can be made by adjusting either the camera controls such as the "IRIS" or "WHITE BALANCE" or adjusting the monitor controls. If adjustments to these are not sufficient in giving a clear picture, then contact the Test Director or COG engineer.

Adjustments are not part of this testing but can be accomplished through use of the manufacture's operating manual.

\subsubsection{Flexible Receiver Sequence}

NOTE:

The following steps are to be performed in the order presented.

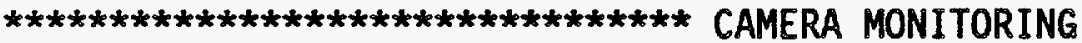

The following test will use Table 2 to describe the flexible receiver cameras being tested and their features. It 27 so includes what they are viewing.

Table 2. Flexible Receiver Camera Features

\begin{tabular}{|c|c|c|c|c||}
\hline \multirow{2}{*}{ Camera } & \multicolumn{3}{|c|}{ OPTIONS } & \multicolumn{1}{c|}{ View } \\
\cline { 2 - 4 } & Zoom & Pan \& Tilt & Lights & \multicolumn{1}{|c|}{} \\
\hline \hline 1 & NO & NO & YES & $\begin{array}{l}\text { Receiver spool and equipment } \\
\text { being removed. }\end{array}$ \\
\hline 2 & N & YES & NO & $\begin{array}{l}\text { Hydraulic gauges and top assembly } \\
\text { on Receiver. }\end{array}$ \\
\hline 3 & NO & YES & NO & $\begin{array}{l}\text { Hydraulic gauges and top assembly } \\
\text { on Receiver. }\end{array}$ \\
\hline 4 & YES & YES & NO & $\begin{array}{l}\text { Overall view of Receiver located } \\
\text { on trailer. }\end{array}$ \\
\hline 5 & YES & YES & NO & Crane operations (optional) \\
\hline
\end{tabular}




\begin{tabular}{|l|l|l|l|l||}
\hline 6 & YES & NO & NO & SPARE \\
\hline
\end{tabular}

8.3.2.1 Perform the following camera tests for each monitor (3 total). Select cameras by the following method: Press a button numbered 1-8 located under each monitor (button \#1 - camera \#1 and so on). When pressed in, verify the button lamp is lit. To deselect a camera, push another button just enough in to cause the first selected button to pop out and the light goes off. Use only 1 monitor per each camera (e.g. . do not have all 3 monitors showing the same camera). This will not harm the system but will degrade the camera signal.

8.3.2.2 For each VCR perform the following step (each VCR corresponds to a monitor eg VCR $1=$ Monitor 1 and so on): Put a VHS tape in the VCR and press the "/FF" (forward), then the "stop", then the "REW/" rewind, then the "stop", then the "play", then "PAUSE /STILL", press "PAUSE/STILL" again then "STOP" and ensure they are operational. Using camera 2, toggle the camera after pressing the "RECORD" and verify each VCR can record by playing it back.

8.3.2.3 Place a tape in each VCR and record all activities of test at the time the Flexible Receiver Bag is being pulled up.

8.3.2.4 For monitor \#1 select Camera 1: On the "CAMERA 1" controls, flip "LIGHT" switch to ON and verify the receiver spool chamber can be clearly seen on the monitors. Deselect Camera 1. Repeat for monitors 2 and 3.

8.3.2.5 For monitor \#1 select Camera 2: On the "CAMERA \#2 PAN TILT" controls, toggle through each position and verify operation of camera position is consistent with view in monitors. Also verify clarity of picture. Deselect Camera 2. Repeat for monitors 2 and 3.

8.3.2.6 For monitor \#1 select Camera 3: On the "CAMERA \#1 PAN TILT" controls, toggle through each position and verify operation of camera position is consistent with view in monitors. Also verify clarity of picture. Deselect Camera 3. Repeat for monitors 2 and 3.

8.3.2.7 For monitor \#1 select Camera 4: On the "CAMERA \#3 PAN TILT" controls, toggle through each position and verify 
operation of camera position is consistent with view in monitors. Also verify clarity of picture. On "CAMERA 4" controls, operate f7ip "Z0OM" switch between "TELE" and "WIDE" and verify the TELE position gives a close view and a WIDE gives a wide view. Deselect Camera 4. Repeat for monitors 2 and 3.

8.3.2.8 Turn off power to camera control units 4 and 5 .

8.3.2.9 Use camera 4 with camera control unit 5 by taking the cable from the camera control unit 4 and connect it to camera control unit 5 .

8.3.2.10 Turn on power to camera control units 4 and 5 .

8.3.2.11 For monitor \#1 select Camera 5: On the "CAMERA \#3 PAN TILT" controls, toggle through each position and verify operation of camera position is consistent with view in monitors. Also verify clarity of picture. On "CAMERA 5". controls flip the "ZOOM" switch between "TELE" and "WIDE" and verify the TELE position gives a close view and the WIDE position gives a wide view. Deselect camera 5. Repeat for monitors 2 and 3.

8.3.2.12 Turn off power to camera control units 4 and 5 .

8.3.2.13 Return use the camera 4 to camera control unit 4 by taking the cable from the camera control unit 5 and connect it to camera control unit 4.

8.3.2.14 Turn on power to camera control units 4 and 5 .

Note: Camera control unit 6 is a spare and does not provide a video signal.

NOTE: ON CAMERAS

Use cameras throughout the test to visually inspect the operation unless called out in the procedure to field-verify. If cameras are unable to sufficiently monitor the operation, then document problem and inform $C O G$ engineer.

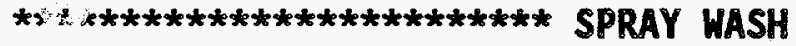

8.3.2.15 Turn on vacuum blower motor.

8.3.2.16 Turn main power disconnect switch on the High Pressure Spray System (HPSS) Pump Trailer to "ON".

8.3.2.17 Verify the green "SYSTEM POWER OFF" indicator light is illuminated on the HPSS Control Panel located in the FR 


\section{Control Trailer.}

8.3.2.18 Turn "SYSTEM POWER" keyswitch located on the HPSS controt panel to the "ON" position. Verify the red "SYSTEM POWER ON" indicator light is 117 uminated and that the green "SYSTEM POWER OFF" light is not illuminated.

8.3.2.19 Visually verify that the HPSS control panel meters have power in the FR Control Trailer.

8.3.2.20 Push "LAMP TEST" button and verify all indicator lamps become illuminated on the HPSS control panel in the FR Control Trailer.

8.3.2.21 Verify the green pilot lamp labeled "CONTINUITY GOOD" under "SYSTEM CONTINUITY" is lit and the red pilot lamp labeled "CONTINUITY LOST" is not lit. Do not proceed until this step is verified unless directed by COG Engineer.

8.3.2.22 Zero the "FLOW TOTALIZER" meter on the HPSS control panel according to the manufacturers instructions in the FR Control Trailer.

Note: Unless otherwise noted, the following steps will all be performed at the HPSS Pump Trailer Control Panel.

8.3.2.23 Zero the "TOTAL FLOW" meter according to the manufacturers instructions on the HPSS Pump Trailer.

8.3.2.24 Place the "LOCAL/REMOTE SWITCH" in the "LOCAL" position.

8.3.2.25 Place the "MOTOR SPEED" switch in the "MINIMUM" position at the HPSS Pump Trailer.

8.3.2.26 Verify that water in the water truck is at least half full.

8.3.2.27 Open the feed water line valve on the water truck.

8.3.2.28 Bleed air from lines to portable feed pump.

8.3.2.29 Start the portable feed pump located between the HPSS Pump Trailer and the water supply truck according to the manufacturers instructions provided by the test director.

8.3.2.30 Pull out the "STOP" button on the HPSS Pump Trailer.

8.3.2.31 Push the "PUMP CONTROL START" button at the HPSS pump trailer. Slowly increase the "MOTOR SPEED" switch to 
obtain discharge pressure of $3000+/-100$ psi or at a discharge pressure directed by the Test Director. Verify the HPSS pump begins operating.

8.3.2.32 Push the "PUMP CONTROL STOP" button at the HPSS Pump

Trailer. Verify the HPSS pump operation is stopped.

8.3.2.33 Place the "MOTOR SPEED" switch in the "MINIMUM" position at the HPSS Pump Trailer.

8.3.2.34 Pull out the "PUMP CONTROL STOP" button.

8.3.2.35 Place the "LOCAL/REMOTE SWITCH" in the remote position.

NOTE: Unless otherwise noted, the following steps will be performed at the HPSS Control Panel located in the FR Control Trajler.

8.3.2.36 Put the "PUMP CONTROL MOTOR SPEED" in the minimum position in the FR Control Trailer.

8.3.2.37 Push the "PUMP CONTROL PUMP MOTOR START" button in the FR Control Trailer. Increase the "PUMP CONTROL MOTOR SPEED" to obtain discharge pressure of $1000+/-100$ psi. Verify the HPSS pump begins operation.

8.3.2.38 Push the "PUMP CONTROL EMERGENCY STOP" button in the FR Control Trailer. Verify the HPSS pump operation is stopped.

8.3.2.39 Put the "PUMP CONTROL MOTOR SPEED" in the minimum position in the FR Control Traiter.

8.3.2.40 Push the "PUMP CONTROL PUMP MOTOR START" button in the FR Control Trailer. Increase the "PUMP CONTROL MOTOR SPEED" to obtain discharge pressure of $1000+/-100$ psi. Verify the HPSS pump begins operation.

8.3.2.41 Push the "PUMP CONTROL STOP" button located at the HPSS Pump Trailer. Verify the HPSS Pump operation is stopped.

8.3.2.42 Push the "PUMP CONTROL STOP" button in the FR Control Trailer.

8.3.2.43 Put the "PUMP CONTROL MOTOR SPEED" at the minimum setting in the FR Control Trailer and pull out the "PUMP CONTROL STOP" button located on the HPSS Pump Trailer.

8.3.2.44 Push the "PUMP CONTROL PUMP MOTOR START" button in the FR Control Trailer. Increase the "PUMP CONTROL MOTOR SPEED" 
to obtain discharge pressure of $3000+/-100$ psi or at a discharge pressure directed by the Test Director. Verify the HPSS pump begins operation.

8.3.2.45 Verify there are no visible leaks in the HPSS or record location of leaks and/or repair leakage and then record the following. Local readings are taken at the HPSS Pump trailer control panel. Remote readings are taken at the HPSS control panel in the FR Control Trailer. "Total Flow" and "Flow Totalizer" readings are to be taken simultaneously. Verify the "Discharge Temperature" is $150^{\circ} \mathrm{F}+10^{\circ} \mathrm{F} /-30^{\circ} \mathrm{F}$ and that local $/$ remote readings are consistent.

\begin{tabular}{|l|r|r|}
\hline & LOCAL & REMOTE \\
\hline Suction Pressure & psi & psi \\
\hline Discharge Pressure & psi & N/A \\
\hline Regulator Discharge Pressure & psi & psi \\
\hline Suction Temperature & ${ }^{\circ} \mathrm{F}$ & N/A \\
\hline Discharge Temperature & ${ }^{\circ} \mathrm{F}$ & ${ }^{\circ} \mathrm{F}$ \\
\hline Flow / Flow Indicator & GPM & GPM \\
\hline Total Flow / Flow Totalizer & Gallons & \multicolumn{2}{|c|}{ Gallons } \\
\hline Ammeter & amps & N/A \\
\hline Frequency Meter & $\mathrm{Hz}$ & \multicolumn{2}{|c|}{ N/A } \\
\hline
\end{tabular}

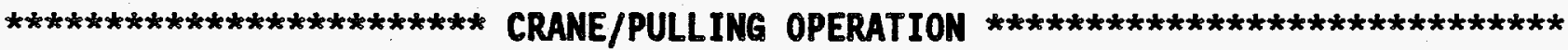

8.3.2.46 Record and verify that the test pit vacuum is between 0.25 and 2 inches of water. Pit Vacuum:

8.3.2.47 Record and verify that the wind velocity is $10 \mathrm{mph}$ or less.

Wind Velocity: $\mathrm{mph}$

8.3.2.48 Attach the crane hook to the eyebolt of the FR bag. Reset the crane total height meter to zero and then raise the crane hook at a constant rate provided by the Test

Director.

8.3.2.49 Start recording on all three VCR's. 
8.3.2.50 Observe the bag rings coming off of the stanchions. Verify there is no binding and that the rings are not separated from the bag.

8.3.2.51 Have crane stop pulling at about $20 \mathrm{ft}$ and lower equipment back down about $8 \mathrm{ft}$. Lowering the bag $8 \mathrm{ft}$ will simulate rewashing a section of the pump. Raise the bag $8 \mathrm{ft}$. After raising the bag the bag should not have overlapped on itself. Performing the next step is at the discretion of the Test Director. Lower the equipment 10 $-15 \mathrm{ft}$ using the emergency ring replacing rod. Verify emergency rod with a hook can help in putting the rings back on the guide poles. Note: When the emergency ring replacing rod is used, the access window needs to be removed causing minimal negative pressure in the bag to facilitate ring replacement.

8.3.2.52 Start raising the bag until the closure indexing lines are in-line (Indexing lines are the lines marked on the stanchions and the first horizontal line on the bag). STOP raising the bag when the indexing lines are in alignment. Record the crane hook elevation ft.

8.3.2.53 Slowly reduce pressure on the HPSS pump by turning the "PUMP CONTROL MOTOR SPEED" to the minimum setting in the FR Control Trailer and press the stop button.

8.3.2.54 Stop the portable feed pump and turn off the feed line valve on the water truck.

8.3.2.55 Turn "HYDRAULIC PWR UNIT" switch to the "ON" position.

8.3.2.56 At the FR control panel, turn and HOLD the "WINCH MOTORS" switch in the "ON" position for 30 to 45 seconds after the cables have stopped (visually determined by camera) and verify wire rope tightens around the bag forming seals both above and below the cutting blade and the bag tie wraps break without tearing the bag. Verify amber light on switch is lit. Verify and record "WINCH MOTORS" "HYDRAULIC PRESSURE" reach $1250 \pm 200$ psig from the control panel meter and local gauge on the receiver. Control Pane1: _ psig Local Gauge: psig

8.3.2.57 Release the "WINCH MOTORS" switch letting it spring return to the "OFF" position. Verify amber light in the switch is not lit. Verify and record "WINCH MOTORS" "HYDRAULIC PRESSURE" reach $0 \pm 100 \mathrm{psig}$ from the local 
gauges on the receiver.

Local Gauge: psig

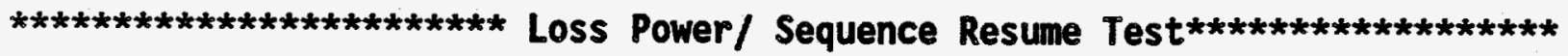

8.3.2.58 Turn the "SYSTEM CONTROL POWER " key switch to the "OFF" position.

8.3.2.59 Wait 5 to 10 seconds, then turn the "SYSTEM CONTROL POWER" key switch to the "ON" position, press and release the "RESET" button.

8.3.2.60 Verify the sequence continues by "HYDRAULIC POWER" light switch illuminated, hydraulic pump is running and by performing the next step which is crimping the cable. If the next step cannot be performed, then Stop test and contact COG engineer or Test Director.
\end{abstract}

8.3.2.61 At the FR control panel in the trailer, turn the "UPPER CABLE CLAMP" switch to "CRIMP" position and hold until pressure on the control panel meter "HYDRAULIC PRESSURE" reaches $3000 \pm 300$ psig. Verify amber. light on switch is lit. Record "UPPER CABLE CLAMP" "HYDRAULIC PRESSURE" from the control panel meter and local gauges on the receiver.

Control Panel: psig Local Gauge: psig

8.3.2.62 Return "UPPER CABLE CLAMP" switch to the "OFF" position. Verify amber light on switch is not lit. Verify and record "UPPER CABLE CLAMP" "HYDRAULIC PRESSURE" returned to $0 \pm 100 \mathrm{psig}$ from the local gauge on the receiver. Local Gauge: psig

8.3.2.63 Turn the "UPPER CABLE CLAMP" switch to "OPEN" position and hold until pressure reading on the control panel meter "UPPER CABLE CLAMP HYDRAULIC PRESSURE" reaches at Teast $500 \pm 200$ psig. Verify amber light on switch is 1it. Record "UPPER CABLE CLAMP HYDRAULIC PRESSURE" from the control panel meter and local gauges on the receiver. Control Panel: psig Local Gauge: psig

8.3.2.64 Return "UPPER CABLE CLAMP" switch to the "OFF" position. Verify amber light on switch is not lit. Verify and record "UPPER CABLE CLAMP" "HYDRAULIC PRESSURE" returned to $0 \pm 100 \mathrm{psig}$ from the local gauges on the receiver. Local Gauge: psig

8.3.2.65 At the FR control panel in the trailer, turn the "LOWER 
CABLE CLAMP" switch to "CRIMP" position and hold until pressure on the control panel meter "LOWER CABLE CLAMP HYDRAULIC PRESSURE" reaches $3000 \pm 300$. psig. Verify amber light on switch is lit. Record "LOWER CABLE CLAMP HYDRAULIC PRESSURE" from the control panel meter and local gauges on the receiver. Contro1 Panel: psig Local Gauge: psig.

8.3.2.66 Return "LOWER CABLE CLAMP" switch to the "OFF" position. Verify amber light on switch is not lit. Verify and record "LOWER CABLE CLAMP" "HYDRAULIC PRESSURE" returned to $0 \pm 100$ psig from the local gauges on the receiver. Local Gauge: psig

8.3.2.67 Turn the "LOWER CABLE CLAMP" switch to "OPEN" position and hold until pressure on the control panel meter "LOWER CABLE CLAMP HYDRAULIC PRESSURE" reaches at least $500 \pm$ 200 psig. Verify amber light on switch is lit. Record "LOWER CABLE CLAMP HYDRAULIC PRESSURE" from the control panel meter and local gauges on the receiver. Control Panel: psig Local Gauge: psig

8.3.2.68 Return "LOWER CABLE CLAMP" switch to the "OFF" position. Verify amber light on switch is not lit. Verify and record "LOWER CABLE CLAMP HYDRAULIC PRESSURE" returned to $0 \pm 100$ psig from the local gauges on the receiver. Local Gauge:__ psig

8.3.2.69 At the FR control panel in the trailer, turn the "BAG CUTTER" switch to the "CLOSE" position and hold until pressure on the control panel meter "BAG CUTTER HYDRAULIC PRESSURE" reaches at least $1000 \pm 300 \mathrm{psig}$, then return switch to the "OFF" position. Verify that the "BAG CUTTER OPENING" amber light is only lit while performing operation. Record final "BAG CUTTER HYDRAULIC PRESSURE" from the control panel meter and local gauges on the receiver. Also visually verify blades at the FR fully closed and the bag is cut.

Control Panel: psig Local Gauge: psig

8.3.2.70 Turn the "BAG CUTTER" switch to the "OPEN" position ard hold until pressure on the control panel meter "BAG CUTTER HYDRAULIC PRESSURE" reaches at least $500 \pm 100$ psig or until blades fully open, then return switch to the "OFF" position. Verify that the "BAG CUTTER/CLOSING" amber light is only lit while performing operation. Record final "BAG CUTTER HYDRAULIC PRESSURE" from the control panel meter and local gauges on the receiver. Control Panel: psig Local Gauge: psig 
CAUTION: In the following step do not hold the cable cutter switch in the "ON" position after the cable has been cut, this will damage the cable cutter.

8.3.2.71 At the FR control panel in the trailer, turn the "CABLE CUTTER UPPER" switch to the "ON" position and hold for 5 sec. or until the cable has been cut, then release the switch to spring return to the "OFF" position. Verify amber light on switch is only lit when switch is in the "ON" position. Visually verify that upper cable has been fully cut and that the clamp has held. (Field verification may also be used.)

CAUTION: In the following step do not hold the cable cutter switch in the "ON" position after the cable has been cut, this will damage the cable cutter.

8.3.2.72 At the FR control pane1, turn the "CABLE CUTTER LOWER" switch to the "ON" position and hold for $5 \mathrm{sec}$. or until the cable has been cut, then release the switch to spring return to the "OFF" position. Verify amber light on switch is only lit when switch is in the "ON" position. Visually verify that lower cable has been fully cut and that the clamp has held. (Field verification may be used.)

\subsubsection{Verify the FR bag is fully cut.}

8.3.2.74 Verify cable is tight around both ends of the bag and has not silipped off.

\subsubsection{Secondary Bagger Operations}

The sealed end of the primary bag is placed in the Secondary bagger machine. A second bag is applied over the lower portion of the Primary bag to provide a secondary "back-up" barrier. The secondary bag is intended to contain contamination on or between the upper cable seal and the bottom of the primary bag.

8.3.3.1 Using the crane move the bagged equipment over to the secondary bagging station and place primary bag in secondary bag approximately 2 to 3 feet. Stop so that the cable on the Secondary Containment Assembly is between the rings of the bag.

8.3.3.2 At the FR control paner, turn and HOLD the "WINCH MOTORS" switch in the "ON" position for 30 to 45 seconds after the cables have stopped (visualiy determined by camera) and verify wire rope tightens around the bag forming seals both above and below the cutting blade and the bag 
tie wraps break without tearing the bag. Verify amber light on switch is lit. Verify and record "WINCH MOTORS" "HYDRAULIC PRESSURE" reach $1250 \pm 200$ psig from the control panel meter and local gauge on the receiver. Control Pane1: psig Local Gauge: psig

8.3.3.3 Return "WINCH MOTOR" switch to the "OFF" position. Verify amber light in the switch is not lit. Verify and record "WINCH MOTORS HYDRAULIC PRESSURE" reach $0 \pm 100$ psig from the local gauges on the secondary bagger. Local Gauge: psig

8.3.3. At the FR control panel under "SECONDARY CONTROL SYSTEM" in the trailer, turn the "CABLE CLAMP" switch to "CRIMP" position and hold until pressure on the control panel meter "CABLE CLAMP HYDRAULIC PRESSURE" reaches $3000 \pm 300$ psig. Verify amber light in the switch is lit when holding. Record "CABLE CLAMP HYDRAULIC PRESSURE" from the control panel meter and local gauges on the secondary bagger.

Control Panel: psig Local Gauge: psig

8.3.3.5 Return "CABLE CLAMP" switch to the "OFF" position. Verify amber light in the switch is not lit. Verify and record "CABLE CLAMP HYDRAULIC PRESSURE" returned to $0 \pm$ 100 psig from the local gauges on the secondary bagger. Local Gauge: psig

8.3.3.6 Turn the "CABLE CLAMP" switch to "OPEN" position and hold until pressure on the control panel meter "CABLE CLAMP HYDRAULIC PRESSURE" reaches $500 \pm 200$ psig. Verify amber light in the switch is lit when holding. Record "CABLE CLAMP HYDRAULIC PRESSURE" from the control panel meter and local gauges on the secondary bagger. Control Panel: psig Local Gauge: psig

8.3.3.7 Return "CABLE CLAMP" switch to the "OFF" position.

Verify amber light in the switch is not lit. Verify and record "CABLE CLAMP HYDRAULIC PRESSURE" returned to $0 \pm$ 100 psig from the local gauges on the sernndary bagger. Local Gauge: psig

CAUTION: In the following step do not hold the cable cutter switch in the "ON" position after the cable has been cut, this will damage the cable cutter.

8.3.3.8 On the FR control panel under "SECONDARY CONTROL SYSTEM" turn the "CABLE CUTTER" switch to the "ON" position and 
hold for 5 sec. or until the cable has been cut, then release the switch to spring return to the "OFF" position. Verify amber light on switch is only lit when switch is in the "ON" position. Visually verify that cable has been fully cut and that the clamp has held. (Field verification may also be used.)

8.3.3.9 Lower the encapsulated simulated pump to the ground. Block as required to prevent the pump from moving. Remove the crane lifting hook from the bag eye.

8.3.3.10 Stop recording on the VCR's.

8.3.3.11 Turn the "HYDRAULIC PWR UNIT" switch to the "OFF" position. Turn the "START SEQUENCE" switch to the "OFF" position. Turn the "SYSTEM CONTROL POWER" switch to the "OFF" position.

\subsubsection{Manual Control}

The use of MANUAL CONTROL requires the use of a key switch. When the MANUAL CONTROL key switch is placed in the ON position, the amber light by the MANUAL CONTROL key switch lights and the controller performs any requested operation without regard to the interlocks or sequence.

NOTE: Operation of the MANUAL CONTROL key switch will disrupt the control sequence. Once the MANUAL CONTROL key switch is used to perform an out of sequence action, the remaining operations must be completed under manual control.

Initial/Date

8.3.4.1 Verify there is power to the FR control rack. This is denoted by a 1 it green lamp labeled "POWER OFF" under "SYSTEM CONTROL POWER".

8.3.4.2 Turn FR control system power ON by rotating "SYSTEM CONTROL POWER" control key to the ON position. A red panel light labeled "POWER ON" under "SYSTEM CONTROL POWER" indicates the power is applied to the Control System when lit.

8.3.4.3 Turn the "START SEQUENCE" key switch to the "ON" position and verify the green pilot lamp labeled "READY" is lit.

8.3.4.4 Turn the "MANUAL CONTROL KEY" to the on position. 
8.3.4.5 Turn "HYDRAULIC PWR UNIT" switch to the "ON" position and verify green lamp in the switch is lit and the Hydraulic power unit motor is operating by visual inspection.

NOTE: The following manual steps are to be field verified since this is only a verification that a function operates.

8.3.4.6 On the FR control panel in the trailer, turn and HOLD the "WINCH MOTORS" switch to the "ON" position and verify motors are operating. Switch to the "OFF" position and verify the motors stop running.

8.3.4.7 On the FR control panel in the trailer under the "SECONDARY / CONTROL / SYSTEM", turn and HOLD the "WINCH MOTOR" switch to the "ON" position and verify motor is operating on the secondary bag receiver. Switch to the "OFF" position and verify it stops running.

8.3.4.8 On the FR control panel in the trailer, turn the "UPPER / CABLE CLAMP" switch to "CRIMP" position and verify panel amber light on switch is lit and in the field, movement of crimper. DO NOT HOLD FOR A LONG PERIOD OF TIME, ONLY VERIFY MOVEMENT OF ACTUATOR.

8.3.4.9 Release the "UPPER CABLE CLAMP" switch so it spring returns to the "OFF" position. Verify amber light in the switch is not lit and in the field, crimper does not move.

8.3.4.10 Turn the "UPPER CABLE CLAMP" switch to "OPEN" position and verify the amber light in the switch is 1 it and in the field, movement of crimper. DO NOT HOLD FOR A LONG PERIOD OF TIME, ONLY VERIFY MOVEMENT OF ACTUATOR.

8.3.4.11 Release the "UPPER CABLE CLAMP" switch to the "OFF" position. Verify the amber light in the switch is not lit and in the field, verify the crimper does not move.

8.3.4.12 On the FR control panel under "SECONDARY CONTROL SYSTEM" turn the "CABLE CLAMP" switcin to "CRIMP" position and verify the amber light in the switch is lit and in the field verify movement of the crimper. DO NOT HOLD FOR A LONG PERIOD OF TIME, ONLY VERIFY MOVEMENT OF ACTUATOR.

8.3.4.13 Release the "CABLE CLAMP" switch to the "OFF" position. Verify the amber light in the switch is not lit and in the field verify the crimper does not move. 
8.3.4.14 Turn the "CABLE CLAMP" switch to "OPEN" position and verify the amber light in the switch is lit. In the field verify movement of the crimper. DO NOT HOLD FOR A LONG PERIOD OF TINE, ONLY VERIFY MOVEMENT OF ACTUATOR.

8.3.4.15 Release the "CABLE CLAMP" switch to the "OFF" position. Verify the amber light in the switch is not lit and in the field verify the crimper does not move.

8.3.4.16 At the FR control panel turn the "LOWER CABLE CLAMP" switch to the "CRIMP" position and verify the amber light in the switch is lit. In the field verify movement of the crimper. DO NOT HOLD FOR A LONG PERIOD OF TIME, ONLY VERIFY MOVEMENT OF ACTUATOR.

8.3.4.17 Release the "LOWER CABLE CLAMP" switch to the "OFF" position. Verify the amber light in the switch is not lit and in the field verify the crimper does not move.

8.3.4.18 Turn the "LOWER CABLE CLAMP" switch to the "OPEN" position and verify the amber light in the switch is 1 it and in the field verify movement of the crimper. DO NOT HOLD FOR A LONG PERIOD OF TIME, ONLY VERIFY MOVEMENT OF ACTUATOR.

8.3.4.19 Release the "LOWER CABLE CLAMP" switch to the "OFF" position. Verify the amber light in the switch is not lit and in the field verify the crimper does not move.

8.3.4.20 At the FR control panel turn the "BAG CUTTER" switch to the "CLOSE" position. Verify that the "BAG CUTTER CLOSING" amber light is only lit while performing the operation. Verify that the bag cutter blades close.

8.3.4.21 Turn the "BAG CUTTER" switch to the "OFF" position. Verify that the "BAG CUTTER" amber light is only lit while performing the operation.

8.3.4.22 Turn the "BAG CUTTER" switch to the "OPEN" position. Verify that the "BAG CUTTER OPENING" amber light is only lit while performing the operation. Verify that the bag cutter blades open.

8.3.4.23 Turn the "BAG CUTTER" switch to the "OFF" position. Verify that the "BAG CUTTER" amber light is only lit while performing the operation.

8.3.4.24 At the FR control panel under "SECONDARY CONTROL SYSTEM" turn the "CABLE CUTTER" switch to the "ON" position and then return it to the "OFF" position. Verify the amber 
light in the switch is only lit when the switch is in the "ON" position. Verify that the cable cutter functions.

8.3.4.25 At the FR control panel turn the "CABLE CUTTER UPPER" switch to the "ON" position and then return it to the "OFF" position. Verify amber light in the switch is only lit when the switch is in the "ON" position. Verify that the cable cutter functions.

8.3.4.26 At the FR control pane1 turn the "CABLE CUTTER LOWER" switch to the "ON" position and then return it to the "OFF" position. Verify the amber light in the switch is only lit when the switch is in the "ON" position. Verify that the cable cutter functions.

\subsubsection{Master Reset}

The control system will initialize/clear all sequential flags etc. and return to the beginning of the operational sequence.

8.3.5.1 Verify the MANUAL CONTROL key switch is in the ON position.

8.3.5.2 Attach the PLC accessories needed to monitor the status of internal coils $300_{\text {HEX }}-307_{\text {HEX }}, 310_{\text {HEX }}-315_{\text {HEX }}$ and $317_{\text {HEX }}$.

8.3.5.3 Press the RESET button. Verify this turns off all internal coils (listed above) from on to off and returns the operational sequence to the beginning of the cycle/sequence. Release the RESET button.

8.3.5.4 Turn the MANUAL CONTROL POWER key switch to the OFF position and remove the key. Remove the PLC accessories.

8.3.5.5 Turn the following power switches to the OFF position.

- Hydraulic Power Unit

- Start Sequence

- Flexible Receiver System Control Power

- High Pressur : Spray System Control Power

\subsection{REFERENCES}

\subsection{DRAWINGS}

For the 42": See H-2-79341 "TWRS Drawing Index 42" Tank 101-AZ Waste Retrieval System" for the list of drawings that apply.

For the 4"-6": See H-2-79335 "TWRS Drawing Index 4"-6" Tank 101-AZ 
Waste Retrieval System" for the list of drawings that apply.

\subsection{VENDOR INFORMATION}

- Series One (tm) Junior Programmable Controller Users Manual by GE Fanuc Automation (part number GEK-90503A, March 1987)

- Operating Instructions - Panasonic, VHS, AG-1970P, Video Cassette Recorder

- Appendix E Model 2380-200 Camera Control Unit - COHU

\subsection{OTHER INFORMATION}

9.3.1 WHC-SD-W151-FDC-001, Rev. 2, "Functional Design Criteria, Project W151, 101-AZ Waste Retrieval System".

9.3.2 WHC-SD-W151-CDR-001, "Conceptual Design Report, Tank 101-AZ Waste Retrieval System, Project W151".

9.3.3 WHC-SD-W151-SDRD-001, "Supplemental Design Requirements Document, 241-AZ-101 Waste Retrieval System".

9.3.4 WHC-SD-W151-CSWD-001, "Design Description for the Flexible Receiver Control System".

9.3.5 WHC-SD-W151-TRP-001, "Interim Development Test Report for Project W151 4/6 Inch Flexible Receiver and Thermocouple Tool".

9.3.6 WHC-SD-W320-FDC-001, Rev 2 "Functional Design Criteria for Tank 241-C-106 Waste Retrieval, Project W-320"

9.3.7 DOE-RL-92-36, "Hanford Site Hoisting and Rigging Manual."

9.3.8 WHC-SD-W151-CSCM-001, Rev O "Software Configuration Management P1 an for the Flexible Receiver Control System"

9.3.9 WHC-SD-W151-ATR-001, "Project W-151 Flexible Receiver Radiation Detector System Acceptance Test Report".

\subsection{DATA SHEETS}

\subsection{TEST EXCEPTION SHEET}

Exception Data Sheets are used to document exceptions to the test procedure and results. A description of the exception and the disposition are provided on the exception sheet. Typical dispositions are:

1. Test approved with exception (i.e., rerun of the acceptance test unnecessary). 
2. Acceptance Test Procedure step(s) affected to be repeated after the discrepancy has been corrected.

The following is the Test Exception Sheet that will be used. Additional copies will be made as needed. 


\section{TEST EXCEPTIONS}

\section{EXCEPTION NO:}

PROCEDURE STEP NO:

DATE:

\section{DESCRIPTION:}

\section{RESOLUTION:}

APPROVALS:

\begin{tabular}{l}
\hline TEST DIRECTOR \\
\hline
\end{tabular}
QUALITY ASSURANCE $\quad$ DATE 


\subsection{TEST LOG SHEET}

Test Log Sheets will be used to document test start and stop times and to document any notes concerning the execution of the Qualification Test Procedure.

The following is the test log sheet that will be used. Additional copies will be made as needed. 


WHC-SD-W320-TIS-001 Rev 2
December 12, 1994
Page 58




\section{$11.04 / 6^{n}$ FLEXIBLE RECEIVER SYSTEMS TEST PROCEDURE}

This procedure will verify (through physically testing) the $4 / 6^{11}$ Flexible Receiver (FR) systems components shall be able to: a) assemble and operate per the drawings and, b) operate in an environmentally safe manner eg no leaks occur that are subjected to fluid mediums. More specifically, it will test the following:

1) Top Assembly from the 42" FR (previously tested) will mate up to the $4 / 6^{\text {n }}$ FR spool assembly and be able to successfully preform its function of cinching, crimping and cutting.

2) Spray wash assembly will be able to mate to a $4^{\text {" }}$ riser, provide a washing stream, and not have any leaks including at the split ring.

3) Bellows/slider and hydraulic jacks will be abe to position FR such that it can provide a stable sealed system for removing equipment.

4) Equipment can be successfully removed from a tank without causing a rip or tear in the bag.

5) Secondary leak container system will be able to cover the primary bag, cinch, crimp and cut secondary bag cable tight.

\subsection{GENERAL SYSTEM REQUIREMENTS}

Cables and pipes are all connected per the FR drawings. The system permissive includes electrical verification that the control cable(s) have been installed.

Operator may use a "manual control" key operated switch to by-pass the normal system interlocks and permissive (under the procedural permission of the Test Director or assigned person-in-charge) in order to deal with an unusual situation.

\subsubsection{TEST CONDITIONS} procedure.

The following items shall be performed prior to other steps of this Initial/Date

11.1.2 Install on CTF the $4^{\prime \prime}$ riser, 4" split adapter, 4" simulated thermocouple tree, and spray ring per drawing $\mathrm{H}-2-79328$.

11.1.3 Install 4/6" flexible receiver spool assembly on CTF and verify bellows connects to spray ring. (This step will require the use of the hydraulic jacks. For use of the hydraulic jacks which requires operation of the hydraulic pump in the control trailer, use steps in 8.3 OPERATIONAL 
SEQUENCE, 8.3.1 START UP SEQUENCE, to operate pUmp. Verification for the operation of the bellows will be done at the end of the test. Slider should be not cover bellows but be open when placing spool assembly. Contact COG (Don Legare) for further installation instructions.)

11.1.4 Instal1 Top Assembly on 4/6" FR spool assembly per H-279328.

11.1.5 Instal1 primary $70 \mathrm{ft}$.bag and cables on $4 / 6^{\prime \prime}$ FR per drawing H-2-79359.

11.1.6 Instal1 4/6" secondary bag and cable on 4/6" leak container bag assembly.

11.1.7 Verify flexible receiver assembly has been properly attached to the Cold Test Facility and support equipment (secondary bagger, control trailer, and high pressure water pump trailer and water truck (if applicable). Ensure hook swivel is attached to the pump lifting device.

11.1.8 Power is OFF to components of systems being tested.

- Switch DSI "MAIN POWER" is off.

- Switch DS2 "HYDRAULIC PWR UNIT" is off.

- Switch DS3 "Tl TRANSFORMER" is off.

- Switch DS4 "HYD POWER UNIT" is off.

11.1.9 All test instruments have a valid calibration stamp attached.

11.1.10 Personnel responsible for directing and witnessing the performance of the tests described in this QTP have read and understand the operation of the equipment to be tested.

11.1.11 All personnel involved in, or witnessing, testing have met the safety requirements listed in section 5.0 .

\subsection{OPERATIONAL SEQUENCE}

The following describes the sequence of events the Flexible Receiver Programmable Logic Controller (PLC) performs in conjunction with the operator(s) actions, and Secondary Bagger equipment. The control logic has 3 major parts: 1) Start up and initial conditions, 2) Operations performed by the Flexible Receiver, and 3) Operations performed by the Secondary Bagger.

The sequence of events are as follows: 1) Start up of equipment; 2) pull equipment out; 3) pull bag tight with cable; 4) clamp cable; 5) cut bag; 6) cut cable; 7) move bagged equipment to secondary bagger; 8) pull secondary bag tight with cable; 9) clamp cable; 10) cut cable. 
If power is unexpectediy lost, the system shuts down and stops as is. Upon restoration of power, the "RESET" button is pressed and the system resumes operation at the step it was last performing before loss of power.

\subsection{START UP SEQUENCE}

WARNING: Turning the HYDRAULIC POWER UNIT key switch, or the START SEQUENCE key switch to OFF, or loss of cable continuity at anytime will deenergize the master system permissive (internal coil 202). The controller will not permit any further actions until corrected.

The following is to be performed on the control panels in the trailer.

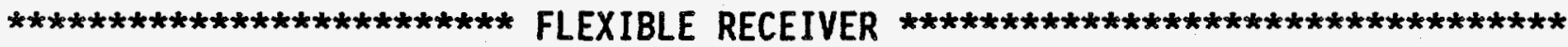

12.1.1 Section 11.2 has been completed.

12.1.1.1 Verify all switches located on the Flexible Receiver and High Pressure Spray control panels are in the OFF

Position before start of testing.

12.1.1.2 Turn on Generator/Site Power per manufacturers instructions provided by the Test Director.

12.1.1.3 Turn Switch DS1 "MAIN POWER" to the "ON" position.

12.1.1.4 Turn Switch DS3 "T1 TRANSFORMER" to the "ON" position.

12.1.1.5 Turn Switch DS4 "HYD POWER UNIT" to the "ON" position.

12.1.1.6 Turn Switch DS2 "HYDRAULIC PWR UNIT" to the "ON" position.

12.1.1.7 There should be power to the FR control rack which will be denoted by a lit green lamp labeled "POWER OFF" under "SYSTEM CONTROL POWER".

12.1.1.8 Turn FR control system power ON by rotating "SYSTEM CONTROL POWER" control key to the ON position. A red panel light labeled "POWER ON" under "SYSTEM CONTROL POWER" indicates the power is applied to the Control System when lit.

12.1.1.9 Push test lamp switch 1abeled "LAMP TEST" and verify that al1 lamps are lit. If a lamp does not light, have the bulb replaced. If the lamp still fails to light, contact the COG before preceding. (This applies to ALL 1 amps on the Flexible Receiver and High Pressure Spray control panels.) 
12.1.1.10 Verify the green pilot lamp labeled "CONTINUITY GOOD" under "SYSTEM CONTINUITY" is lit and the red pilot lamp labeled "CONTINUITY LOST" is not 1it. Do not proceed until this step is verified unless directed by COG Engineer.

12.1.1.11 Turn the "START SEQUENCE" key switch to the "ON" position, a green pilot lamp labeled "READY" should be iit.

12.1.1.12 Turn the "MANUAL CONTROL KEY" to the on position.

12.1.1.13 Push the "RESET" button.

12.1.1.14 Turn the "MANUAL CONTROL KEY" to the off position.

12.1.1.15 Turn "HYDRAULIC PWR UNIT" switch to the "ON" position, green lamp in the switch is lit and the Hydraulic power unit motor is operating should be operating.

12.1.1.16 "SYSTEM HYDRAULIC PRESSURE" panel meter is reading $0 \pm$ 100 (psig).

12.1.1.17 Pressure gages on hydraulic pump in trailer, cable cutter, bag cutter, cable tie clamp, winch motors, jacks on the receiver unit, bellows separator (only on the 4"6" FR), and secondary cable tie clamp and winch motor should read $0 \pm 100$ psig or has a blank meter screen. Only the meters associated with a function that is currently being used will show a pressure reading. If the meter reads 100 or greater before the starting that sequence, contact COG before proceeding.

12.1.1.18 Verify hydraulic connections are not leaking. If piping requires tightening, then turn "HYDRAULIC PWR UNIT" switch to the "OFF" position and resolve leak. Restart system by repeating steps previous steps.

\section{CAMERA MONITORING}

12.1.1.19 Under monitor \#3, f1 ip the "POWER" switches on camera control units 1 through 4 to the "ON" position and verify the green lights labeled "POWER" is 1 it for each controller. Turn on camera control unit 1 camera lights.

12.1.1.20 Turn on VCR's 1 through 3 by pressing "POWER" button and ensure the "POWER" light for each is on. Put a tape in each. 
12.1.1.21 Turn on the "SONY" Video monitors by pushing in the "POWER" button and verify that the green light for each is $1 \mathrm{it}$.

12.1.1.22 Turn on the Pan Tilt power.

12.1.1.23 Select camera's 1,2 and 4 for monitors 1 through 3 by pushing the appropriate button under each monitor.

12.1.1.24 Move the switch from the "OFF" position to "VERTICAL" position on the time/date generators 1-3 and put the correct time and date in on each monitor.

12.1.1.25 Record the testing by pressing the record buttons on the VCRs and adjust cameras to desired viewing. COG will direct what and when should be recorded for testing. Table 2 of section 8 gives additional information on the cameras.

NOTE: ON CAMERAS

Adjustments to picture can be made by adjusting either the camera controls such as the "IRIS" or "WHITE BALANCE" or adjusting the monitor controls. If adjustments to these are not sufficient in giving a clear picture, then contact the Test Director or COG engineer.

Adjustments can be accomplished through use of the manufacture's operating manual.

\subsection{Flexible Receiver Sequence}

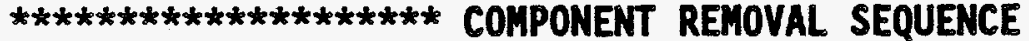

12.2.1 Turn on vacuum blower motor for the CTF.

12.2.2 Record the test pit vacuum.

Pit Vacuum:

12.2.3 Record and verify that the wind velocity is $10 \mathrm{mph}$ or 1 ess. Wind Velocity: $\mathrm{mph}$

12.2.4 Start recording on all three VCR's.

12.2.5 Reset the crane total height meter to zero and then raise the crane hook at a constant rate provided by the Test Director.

12.2.6 Observe the bag rings coming off of the stanchions. Verify 
there is no binding and that the rings are not separated from the bag.

12.2.7 Lift the $4 "$ thermocouple tree until the bottom of the shield plug is in view of the internal camera. At this point stop and proceed with starting the High Pressure Spray System.

12.2.8 Turn main power disconnect switch on the High Pressure Spray System (HPSS) Pump Trailer to "ON". (Remote plug should be connected and the remote switch be positioned to "REMOTE" on the HPSS trailer.)

12.2.9 Green "SYSTEM POWER OFF" indicator light should be lit on the HPSS Control Panel located in the FR Control Trailer.

12.2.10 In the Control Trailer, turn "SYSTEM POWER" keyswitch located on the HPSS control panel to the "ON" position. Red "SYSTEM POWER ON" indicator light should be lit and green "SYSTEM POWER OFF" light is not lit.

12.2.11 Visually inspect that the HPSS control panel meters have power in the FR Control Trailer.

12.2.12 On the HPSS control panel in the FR Control Trailer, push "LAMP TEST" button and verify all indicator lamps are lit, depress and lamps should go off except for the power. If not, contact COG.

12.2.13 Verify the green pilot lamp labeled "CONTINUITY GOOD" under "SYSTEM CONTINUITY" is lit and the red pilot lamp labeled "CONTINUITY LOST" is not lit. Do not proceed until this step is verified unless directed by COG Engineer.

12.2.14 Zero the "FLOW TOTALIZER" meter on the HPSS control pane1 according to the manufacturers instructions in the FR Control Trailer.

12.2.15 Zero the "TOTAL FLOW" meter according to the manufacturers instructions on the HPSS Pump Trailer.

12.2.16 Verify that water in the water truck is at least half full.

12.2.17 Open the feed water line valve on the water truck.

12.2.18 Bleed air from lines to portable feed pump.

12.2.19 Start the portable feed pump located between the HPSS Pump Trailer and the water supply truck according to the manufacturers instructions provided by the test director. 
12.2.20 Pull out the "STOP" button on the HPSS Pump Trailer.

NOTE: Unless otherwise noted, the following steps will be performed at the HPSS Control Panel located in the FR Control Trailer.

12.2.21 Verify on both local and remote gauges that suction pressure is above 50 psig.

12.2.22 Put the "PUMP CONTROL MOTOR SPEED" in the 9 o-clock position.

12.2.23 Push the "PUMP CONTROL PUMP MOTOR START" button. Rotate the "PUMP CONTROL MOTOR SPEED" switch clockwise until a discharge pressure of $3000+1-100$ psi.

12.2.24 Verify there are no visible leaks in the HPSS or record location of leaks and/or repair leakage and then record the following. Local readings are taken at the HPSS Pump trailer control panel. Remote readings are taken at the HPSS control panel in the FR Control Trailer. "Total Flow" and "Flow Totalizer" readings are to be taken simultaneously. Verify the "Discharge Temperature" is $150^{\circ} \mathrm{F}$ $+10^{\circ} \mathrm{F} /-30^{\circ} \mathrm{F}$ and that $10 \mathrm{cal} /$ remote readings are consistent.

\begin{tabular}{|l|r|r|}
\hline & LOCAL & REMOTE \\
\hline Suction Pressure & psi & psi \\
\hline Discharge Pressure & psi & N/A \\
\hline Regulator Discharge Pressure & $\mathrm{psi}$ & psi \\
\hline Suction Temperature & ${ }^{\circ} \mathrm{F}$ & $\mathrm{N} / \mathrm{A}$ \\
\hline Discharge Temperature & ${ }^{\circ} \mathrm{F}$ & ${ }^{\circ} \mathrm{F}$ \\
\hline Flow / Flow Indicator & $\mathrm{GPM}$ & $\mathrm{GPM}$ \\
\hline Total Flow / Flow Totalizer & Gallons & \multicolumn{2}{|c|}{ Gallons } \\
\hline Ammeter & $\mathrm{amps}$ & $\mathrm{N} / \mathrm{A}$ \\
\hline Frequency Meter & $\mathrm{Hz}$ & \multicolumn{2}{|c|}{$\mathrm{N} / \mathrm{A}$} \\
\hline
\end{tabular}

12.2.25 Have crane stop pulling at about $20 \mathrm{ft}$ and lower equipment back down about $8 \mathrm{ft}$. Lowering the bag $8 \mathrm{ft}$ will simulate rewashing a section of the pump. Raise the bag $8 \mathrm{ft}$. After raising the bag the bag should not have overlapped on itself. Performing the next step is at the discretion of 
the Test Director. Lower the equipment $10-15 \mathrm{ft}$. Emergency ring replacing rod may be used if so directed by the COG. If ring is used, then vacuum will have to be shut off.

12.2.26 Start raising the bag until the closure indexing lines are in-line (Indexing lines are the lines marked on the stanchions and the first horizontal line on the bag). STOP raising the bag when the indexing lines are in alignment.

Record the crane hook elevation $f t$.

12.2.27 On the HPSS control panel in the FR Control Trailer slowly return the "PUMP CONTROL MOTOR SPEED" to the " 6 o-clock position reducing the discharge pressure and press the "STOP" button. HPSS should have stopped. If HPSS has not stopped contact COG. Press the stop button on the HPSS trailer.

12.2.28 Stop the portable feed pump and turn off the feed line valve on the water truck.

12.2.29 In the Control Trailer, turn "SYSTEM POWER" keyswitch located on the HPSS control panel to the "OFF" position.

12.2.30 On the FR control panel, turn and HOLD the "WINCH MOTORS" switch in the "ON" position for 30 to 45 seconds after the cables have stopped (visually determined by camera) and verify wire rope tightens around the bag forming seals both above and below the cutting blade and the bag tie wraps break without tearing the bag, amber light on switch should be lit. "WINCH MOTORS" "HYDRAULIC PRESSURE" should reach $1250 \pm 200$ psig on both local and Control Trailer gauges.

12.2.31 Release the "WINCH MOTORS" switch letting it spring return to the "OFF" position, amber light in the switch should not be lit. "WINCH MOTORS" "HYDRAULIC PRESSURE" should return to $0 \pm 100$ psig on both local and Control Trailer gauges.

12.2.32 On the FR control panel $\because$ the trailer, turn the "UPPER CABLE CLAMP" switch to "CRIMP" position and hold until pressure on the control panel meter "HYDRAULIC PRESSURE" reaches $3000 \pm 300 \mathrm{psig}$, amber light on switch should be lit.

12.2.33 Return "UPPER CABLE CLAMP" switch to the "OFF" position and amber light on switch should be not be lit. "UPPER CABLE CLAMP" "HYDRAULIC PRESSURE" should return to $0 \pm 100 \mathrm{psig}$ on 
both local and Control Trailer gauges.

12.2.34 Turn the "UPPER CABLE CLAMP" switch to "OPEN" position and hold until pressure reading on the control panel meter "UPPER CABLE CLAMP HYDRAULIC PRESSURE" reaches at least 500 psig on both local and Control Trailer gauges and amber light on switch should be lit.

12.2.35 Return "UPPER CABLE CLAMP" switch to the "OFF" position and amber light on switch should not be lit. "UPPER CABLE CLAMP" "HYDRAULIC PRESSURE" should return to $0 \pm 100$ psig on both local and Control Trailer gauges.

12.2.36 On the FR control panel in the trailer, turn the "LOWER CABLE CLAMP" switch to "CRIMP" position and hold until pressure on the control panel meter "LOWER CABLE CLAMP HYDRAULIC PRESSURE" reaches $3000 \pm 300$ psig, amber light on switch should be lit.

12.2.37 Return "LOWER CABLE CLAMP" switch to the "OFF" position and amber light on switch should be not be lit. "LOWER CABLE CLAMP" "HYDRAULIC PRESSURE" should return to $0 \pm 100 \mathrm{psig}$ on both local and Control Trailer gauges.

12.2.38 Turn the "LOWER CABLE CLAMP" switch to "OPEN" position and hold until pressure reading on the control panel meter "LOWER CABLE CLAMP HYDRAULIC PRESSURE" reaches at least 500 psig on both local and Control Trailer gauges and amber light on switch should be lit.

12.2.39 Return "LOWER CABLE CLAMP" switch to the "OFF" position and amber light on switch should not be lit. "LOWER CABLE CLAMP" "HYDRAULIC PRESSURE" should return to $0 \pm 100$ psig on both local and Control Trailer gauges.

12.2.40 On the FR control panel in the trailer, turn the "BAG CUTTER" switch to the "CLOSE" position and hold until pressure on the control panel meter "BAG CUTTER HYDRAULIC PRESSURE" reaches at least $1000 \pm 300 \mathrm{psig}$, then return switch to the "OFF" position. The "BAG CUTTER OPENING" amber light should only be lit while performing operation. Visually verify blades at the FR fully closed and the bag is cut.

12.2.41 Turn the "BAG CUTTER" switch to the "OPEN" position and hold unti1 pressure on the control panel meter "BAG CUTTER HYDRAULIC PRESSURE" reaches at least 500 psig or until blades fully open, then return switch to the "OFF" position. The "BAG CUTTER/CLOSING" amber light should only be lit while performing operation. 
CAUTION: In the following steps do not hold the cable cutter switch in the "ON* position after the cable has been cut, this will damage the cable cutter.

12.2.42 On the FR control panel in the trailer, turn the "CABLE CUTTER UPPER" switch to the "ON" position and hold until the cable has been cut, then release the switch to spring return to the "OFF" position. Amber light on switch should only be lit when switch is in the "ON" position. Visually verify that upper cable has been fully cut and that the clamp has held. (Field verification may also be used.)

12.2.43 On the FR control panel, turn the "CABLE CUTTER LOWER" switch to the "ON" position and hold until the cable has been cut, then release the switch to spring return to the "OFF" position. Amber light on switch is should only be lit when switch is in the "ON" position. Visually verify that lower cable has been fully cut and that the clamp has held. (Field verification may be used.)

12.2.44 Verify the FR bag is fully cut.

12.2.45 Verify cable is tight around both ends of the bag and has not slipped off.

12.2.46 Turn off vacuum blower motor for the CTF.

12.2.47 Record the crane total height meter. Crane Height: $\mathrm{ft}$

\subsection{SECONDARY BAGGER OPERATIONS}

The sealed end of the primary bag is placed in the Secondary Bag Leak Container. A second bag is applied over the lower portion of the Primary bag to provide a secondary "back-up" barrier. The secondary bag is intended to contain contamination on or between the upper cable seal and the bottom of the primary bag.

12.3.1 Using the cme move the bagged equipment over to the Secondary bayging station and place primary bag in Secondary bag approximately 2 to 3 feet. Stop so that the cable on the Secondary Containment Assembly is between the rings of the bag.

12.3.2 At the FR control panel, turn and HOLD the "WINCH MOTORS" switch in the "ON" position for 30 to 45 seconds after the cables have stopped (visually determined by camera) and 
verify wire rope tightens around the bag forming seals both above and below the cutting blade and the bag tie wraps break without tearing the bag. Verify amber light on switch is lit. Verify and record "WINCH MOTORS" "HYDRAULIC PRESSURE" reach $1250 \pm 200$ psig from the control panel meter and local gauge on the receiver.

Control Panel: psig Local Gauge: psig

12.3.3 Return "WINCH MOTOR" switch to the "OFF" position. Verify amber light in the switch is not lit. Verify and record "WINCH MOTORS HYDRAULIC PRESSURE" reach $0 \pm 100$ psig from the local gauges on the secondary bagger.

Local Gauge: psig

12.3.4 At the FR control panel under "SECONDARY CONTROL SYSTEM" in the trailer, turn the "CABLE CLAMP" switch to "CRIMP" position and hold until pressure on the control panel meter "CABLE CLAMP HYDRAULIC PRESSURE" reaches $3000 \pm 300$ psig. Verify amber light in the switch is lit when holding. Record "CABLE CLAMP HYDRAULIC PRESSURE" from the control panel meter and local gauges on the secondary bagger.

Control Panel: psig Local Gauge: psig

12.3.5 Return "CABLE CLAMP" switch to the "OFF" position. Verify amber light in the switch is not lit. Verify and record "CABLE CLAMP HYDRAULIC PRESSURE" returned to $0 \pm 100$ psig from the local gauges on the secondary bagger.

Local Gauge: psig

12.3.6 Turn the "CABLE CLAMP" switch to "OPEN" position and hold unti1 pressure on the control pane1 meter "CABLE CLAMP HYDRAULIC PRESSURE" reaches at least 500 psig. Verify amber light in the switch is 1 it when holding. Record "CABLE CLAMP HYDRAULIC PRESSURE" from the control panel meter and local gauges on the secondary bagger.

Contro? Panel: psig tocal Gauge: psig

12.3.7 Return "CABLE CLAMP" switch to the "OFF" position. Verify amber light in the switch is not lit. Verify and record "CABLE CLAMP HYDRAULIC PRESSURE" returned to $0 \pm 100 \mathrm{psig}$ from the local gauges on the secondary bagger.

Local Gauge: psig 


\section{APPENDIX A}

42 FR Approved/Performed Test Procedures and Exceptions 
Reference

QUALIFICATION TEST FOR THE FLEXIBLE RECEIVER

WHC-SD-W320-TIS-001 Rev 2

November 4, 1994 


\section{Reference-}

TABLE OF CONTENTS

PAGE

APPROVAL/SIGNATURE PAGES

1.0 TEST ITEM IDENTIFICATION . . . . . . . . . . 24

1.1 FLEXIBLE RECEIVER . . . . . . . . . . . . 24

2.0 GENERAL DESCRIPTION ................... 29

2.1 TEST OBJECTIVES ................. 29

3.0 TEST CONDITION LIMITS . . . . . . . . . . . . . . 29

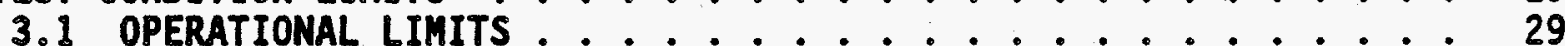

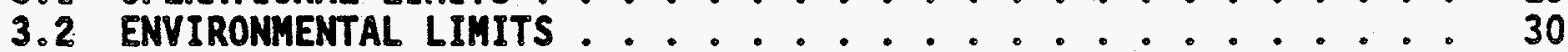

4.0 FACILITIES, EQUIPMENT, AND MATERIALS . . . . . . . . . . . 30

4.1 TEST FACILITY ................... 30

4.2 EQUIPMENT ..................... 30

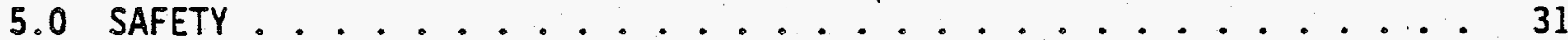

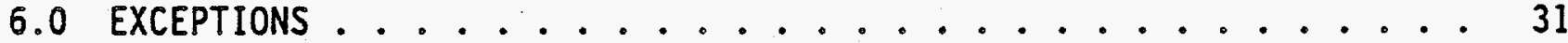

7.0 PERSONNEL REQUIREMENTS .................... 32

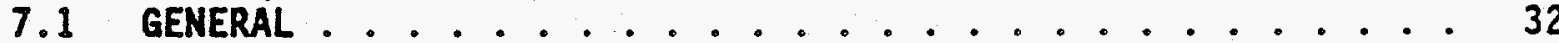

7.2 TEST DIRECTOR . . . . . . . ........ 32

7.3 WITNESSES ................... 33

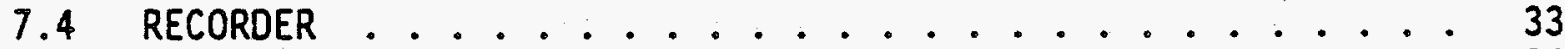

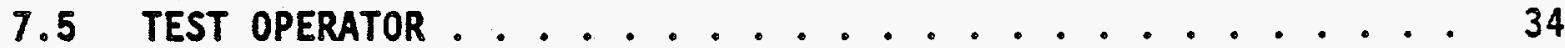

8.0 TEST PROCEDURE . . . . . . . . . . 34

8.1 GENERAL SYSTEM REQUIREMENTS ............... . . . 34

8.2 TEST CONDITIONS .................. 35

8.3 OPERATIONAL SEQUENCE ................. 36

8.3 .1 Start Up Sequence ............... 36

8.3.2 Flexible Receiver Sequence .......... 39

8.3.3 Secondary Bagger Operations .......... 48

8.3 .4 Manual Control ............. 50

8.3.5 Master Reset................ 53

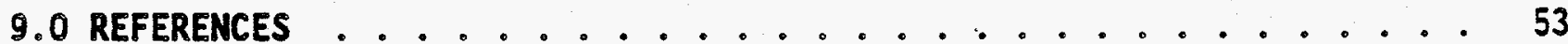

9.1 DRAWINGS ...................... 53

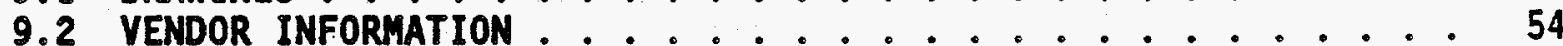

9.3 OTHER INFORMATION ................. 54

10.0 DATA SHEETS .................... 54

10.1 TEST EXCEPTION SHEET ............... . . 54

10.2 TEST LOG SHEET . . . . . . . . . . . . . 57 
Reference-

\section{List of Figures}

1. Flexible Receiver Systems . . . . . . . . . 26

2. Typical $42^{\prime \prime}$ Flexible Receiver Located On A Tank $\cdots: \ldots$

3. Typical 4"-6" Flexible Receiver Located On A Tank . . . . . . . 28 


\section{PERSONNEL INVOLVED IN THE QUALIFICATION TESTING OF THE 42" FLEXIBLE RECEIVER}

ALL NAMES ON THIS PAGE ARE TO BE PRINTED, SIGNED, AND INITIALED FOR CLARIFICATION.

EXECUTED BY:

DAYE Sparks Add.

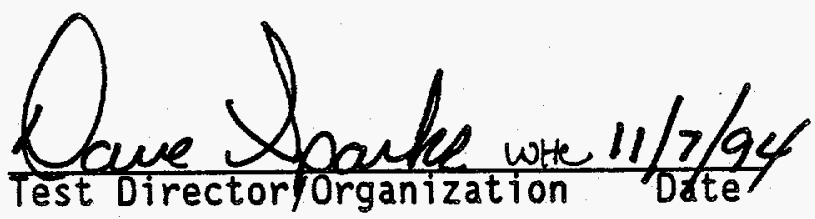

DARYL KANDLER Wilk.

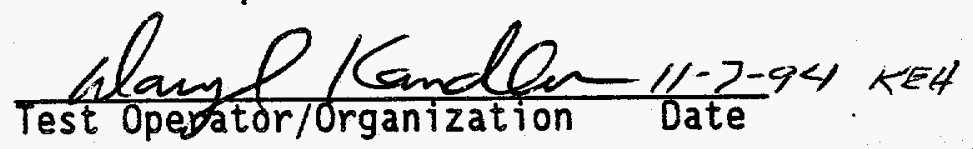

KRL

RIANE R. LESSER

Yhane Rless $k$ KeH $11 / 7 / 94$

Mark A. Mok ler MAM Nowh on/ohlukaull/7/ay

WITNESSES:

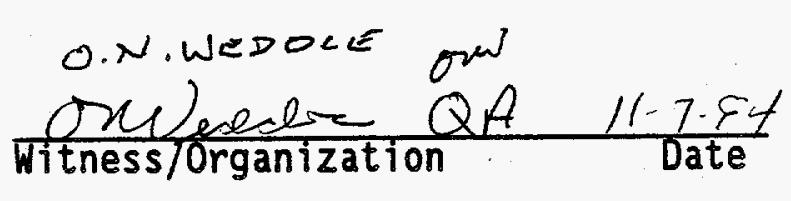

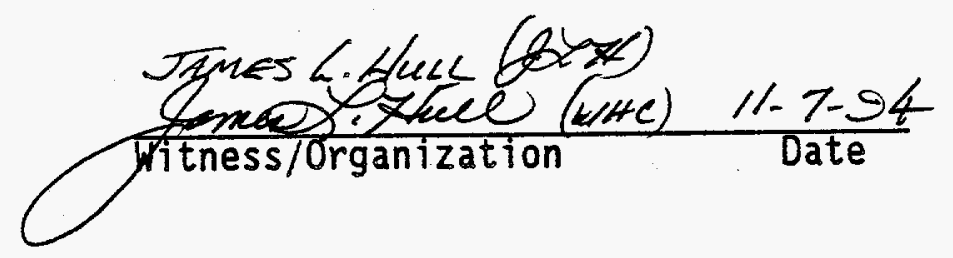

scpH Brundketse SB
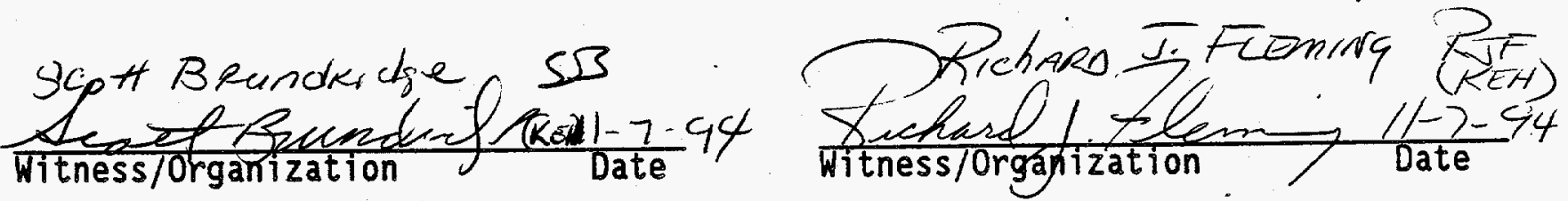


\section{PERSONNEL INVOLVED IN THE QUALIFICATION TESTING}

OF THE 4"-6" FLEXIBLE RECEIVER

ALL NAMES ON THIS PAGE ARE TO BE PRINTED, SIGNED, AND INITIALED FOR CLARIFICATION.

EXECUTED BY:

Test Director/Organization Date

Recorder/Organization

WITNESSES:

Witness/Organization

Date

Witness/Organization

Date
Test Operator/Organization Date

Test Operator/Organization Date
Witness/Organization Date

Witness/Organization Date 
Reference.

TEST APPROVAL AND ACCEPTANCE OF 42" FLEXIBLE RECEIVER

These signatures approve with exceptions that the 42" Flexible Receiver is qualified for use in the field based on the results from these tests.
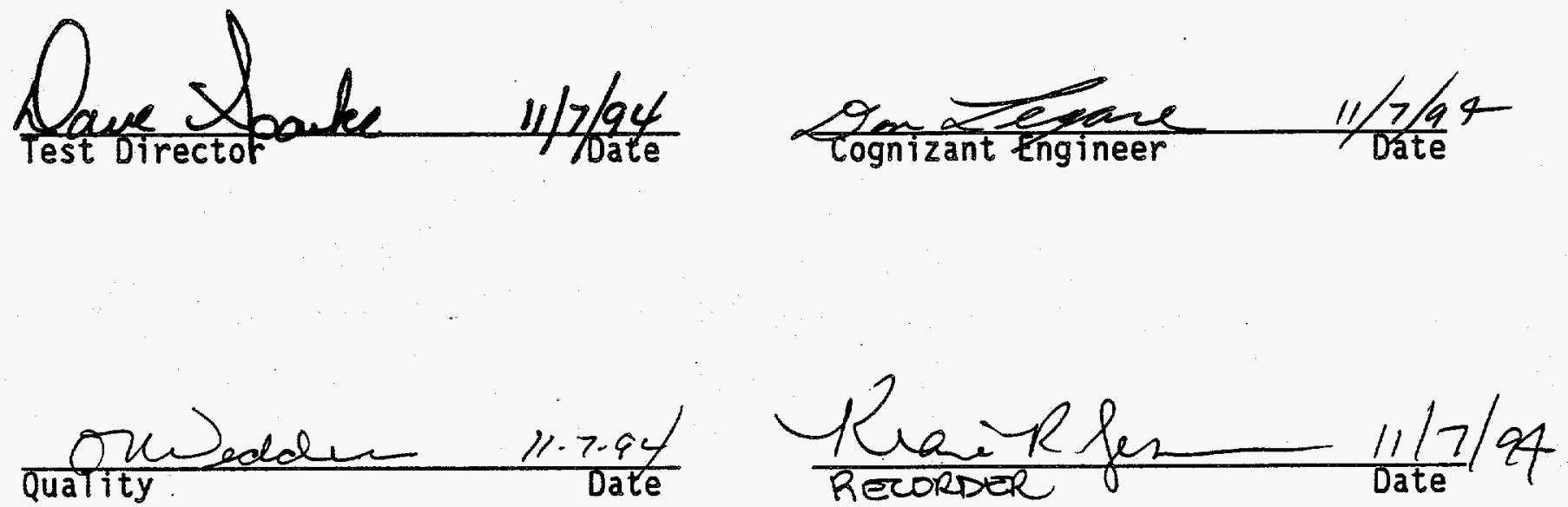

Comments: 


\section{TEST APPROVAL AND ACCEPTANCE OF $4^{\prime \prime}-6^{n}$ FLEXIBLE RECEIVER}

These signatures approve with exceptions that the 4"-6" Flexible Receiver is qualified for use in the field based on the results from these tests.

\section{Comments:}




\section{PURPOSE AND SCOPE OF DOCUMENT}

This document provides the test $\mathrm{plan}$ and procedures to certify and design verify the 42" and 4"-6" Flexible Receiver (FR) as a safety class 3 system. Verification of the design will be handled in two parts. The first part will be to show that it meets design requirements set forth by documents and the second part will perform test(s) to verify its operational aspects.

\section{PART I DESIGN VERIFICATION BASED ON REQUIREMENTS}

The following is a table that defines the documents, their requirements, and specifies FR compliance.

\begin{tabular}{|c|c|c|c|}
\hline $\begin{array}{l}\text { Item } \\
\text { No. }\end{array}$ & Document and Requirement & $\begin{array}{l}\text { Comply } \\
Y \text { or } N\end{array}$ & Remarks or Comments \\
\hline 1 & $\begin{array}{l}\text { WHC-CM-6.1 EP } 1.4 \text { APPENDIX } \\
\text { B } \\
\text { Safety class } 3 \text { and non-safety } \\
\text { class } 4 \text { items must meet the } \\
\text { requirements of DOE Order } \\
6430.1 \text { f for non-safety class } \\
\text { facilities and SDC } 4.1 \text {. } \\
\text { Applicable conventional } \\
\text { standards shall be applied to } \\
\text { safety class } 3 \text { items. }\end{array}$ & $Y$ & $\begin{array}{l}\text { This system has met the applicable } \\
\text { requirements of DOE } 6430.1 A \text {. All } \\
\text { trailers have been designed to the } \\
\text { requirements of SDC } 4.1 \text {. For the } \\
\text { new trailer: Per } H-2-78935 \text { rev } 2 \text {, } \\
\text { the trailer is purchased to meet } \\
\text { the requirements of SDC } 4.1 \text {. } \\
\text { For the retrofit trailer: This } \\
\text { trailer was designed and } \\
\text { constructed and reevaluated for SDC } \\
4.1 \text { per WHC-SD-WM-SA-089. } \\
\text { For the Flexible Receiver: This } \\
\text { has been designed for a } 70 \text { MPH (UBC } \\
\text { requirement) wind and will } \\
\text { withstand it per WHC-SD-W151-DA- } \\
\text { o03. All other design factors } \\
\text { (snow, earthquake, ash) are less } \\
\text { severe and are therefore covered by } \\
\text { the wind load evaluation. } \\
\text { Applicable industrial type } \\
\text { standards have been used (as shown } \\
\text { in the FDC's for both Project W320 } \\
\text { and W151) to meet the requirements } \\
\text { for a safety class } 3 \text { piece of } \\
\text { equipment. }\end{array}$ \\
\hline
\end{tabular}

This is a total rewrite, therefore, pevision bars were not used. 


\begin{tabular}{|c|c|c|c|}
\hline $\begin{array}{l}\text { Item } \\
\text { No. }\end{array}$ & Document and Requirement & $\begin{array}{l}\text { Comply } \\
Y \text { or } N\end{array}$ & Remarks or Comments \\
\hline 2 & $\begin{array}{l}\text { WHC-CM-6.1 EP 2.1 } \\
\text { Software is managed in } \\
\text { accordance to EP 2.1 }\end{array}$ & $Y$ & $\begin{array}{l}\text { There are two types of software } \\
\text { used on the flexible receiver. 1) } \\
\text { Ladder logic that controls the } \\
\text { receiver systems for bagging. This } \\
\text { is documented in the "Software } \\
\text { Configuration Management Plan For } \\
\text { The Flexible Receiver Control } \\
\text { System" WHC-SD-WI51-CSCM-001, Rev } \\
\text { o. 2) VAX software and program } \\
\text { used in the GAMMA ASSAY. This } \\
\text { software manipulates and processes } \\
\text { information sent from the probes } \\
\text { via the nucleonics. Each software } \\
\text { will have a table of description to } \\
\text { fill out on it. }\end{array}$ \\
\hline 3 & $\begin{array}{l}\text { WHC-CM-1-3 MRP } 5.46 \text { REV } 4 \\
\text { Safety class } 3 \text { items shal1 be } \\
\text { incorporated into safety } \\
\text { equipment } 1 \text { ists individually } \\
\text { or by reference to the system } \\
\text { including the subject item. } \\
\text { A system reference implies } \\
\text { that all items in the system } \\
\text { are Safety Class } 3 \text {. }\end{array}$ & Y & $\begin{array}{l}\text { The PSAR (WHC-SD-W15I-PSAR-00I Rev } \\
\text { 0) for Project W151 views the } \\
\text { flexible receiver as a system and } \\
\text { classifies it as safety class } \\
\text { three. Project W320 also covers } \\
\text { this as a system in the Preliminary } \\
\text { Safety Evaluation WHC-SD-WM-PSE- } \\
010 \text {. }\end{array}$ \\
\hline 4 & $\begin{array}{l}\text { WHC-CM-1-3 MRP } 5.46 \text { REV } 4 \text { OA } \\
\frac{\text { Requirements }}{\text { As a minimum, conventional }} \\
\text { industrial standards (NEC } \\
\text { NFPA, Mil Stds ...) shall be } \\
\text { applied to WHC safety class } 3 \\
\text { items. }\end{array}$ & $Y$ & Same as in item 1 . \\
\hline
\end{tabular}




\begin{tabular}{|c|c|c|c|}
\hline $\begin{array}{l}\text { Item } \\
\text { No. }\end{array}$ & Document and Requirement & $\begin{array}{l}\text { Comply } \\
Y \text { or } N\end{array}$ & Remarks or Comments \\
\hline 5 & $\begin{array}{l}\text { sect } 2.2 .4 \text { The retrieval } \\
\text { system shall be designed to } \\
\text { minimize the generation of } \\
\text { new } 1 \text { iquid waste created as a } \\
\text { result of the retrieval } \\
\text { operations. }\end{array}$ & Y & $\begin{array}{l}\text { The only waste the system will } \\
\text { produce will be in the washing of } \\
\text { equipment as it is being pulled } \\
\text { out. Hot water will spray out of a } \\
\text { ring of nozzles at } 50 \mathrm{gpm} \text { (max), } \\
\text { then it is routed into the tank. } \\
\text { The amount of water expected to be } \\
\text { used will be } 2500 \text { ( } \pm 500 \text { ) gallons } \\
\text { for a } 50 \text { foot long piece of } \\
\text { equipment at an extrusion rate of I } \\
\text { ft per minute. See FDC WHC-S-037. }\end{array}$ \\
\hline 6 & $\begin{array}{l}\text { sect } 2.2 .4 \text { The retrieval } \\
\text { equipment shall be remotely } \\
\text { operable from a control room } \\
\text { located outside the Tank Farm } \\
\text { radiation zone. }\end{array}$ & $Y$ & $\begin{array}{l}\text { This requirement was clarified in } \\
\text { Internal Memo } 7 F 820-94-008 \text {, Project } \\
93 L-E W W-320, \text { Tank } 241-C-106 \\
\text { Sluicing, Letter of Clarification, } \\
\text { Equipment Removal system Control } \\
\text { Trailer Requirements to pertain to } \\
\text { only the control room for the tank } \\
\text { waste sluicing operation. The } \\
\text { clarification excludes the } \\
\text { Equipment Removal System from this } \\
\text { requirement. Since the Flexible } \\
\text { Receiver is part of the Equipment } \\
\text { Removal system it is not required } \\
\text { that its control trailer be located } \\
\text { outside the Tank Farm radiation } \\
\text { zone. The Flexible Receiver } \\
\text { control trailer will be located } \\
\text { approximately } 100 \text { ft away from the } \\
\text { area of equipment operation. }\end{array}$ \\
\hline 7 & $\begin{array}{l}\text { sect } 2.2 .4 \text { Systems operation } \\
\text { shall be in accordance with } \\
\text { ALARA principles. }\end{array}$ & $Y$ & $\begin{array}{l}\text { This operation will be remotely } \\
\text { handled such that few if any } \\
\text { person(s) will need to be close to } \\
\text { the actual operation. Emergency } \\
\text { devices, such as in the event the } \\
\text { bag does not get fully cut and it } \\
\text { will be necessery to manually cut } \\
\text { the bag, will account for } \\
\text { minimizing distance by placing tool } \\
\text { on an extension rod. }\end{array}$ \\
\hline
\end{tabular}


Reference-

WHC-SD-W320-TIS-001 ReV 2

November 4, 1994

Page 4

\begin{tabular}{|c|c|c|c|}
\hline $\begin{array}{l}\text { Item } \\
\text { No. }\end{array}$ & Document and Requirement & $\begin{array}{l}\text { Comply } \\
\text { Y or N }\end{array}$ & Remarks or Comments \\
\hline 8 & $\begin{array}{l}\text { sect } 2.2 .4 \text { Human factors } \\
\text { engineering shall be } \\
\text { performed in accordance with } \\
\text { DOE Order } 6430.1 A_{\text {, General }} \\
\text { Design Criteria (DOE 1989), } \\
\text { to enhance assembly, } \\
\text { operation, maintenance, and } \\
\text { disassembiy of the retrieval } \\
\text { system, and to minimize the } \\
\text { potential for operator error. }\end{array}$ & $Y$ & $\begin{array}{l}\text { This feature will only apply to the } \\
\text { controls and trailer used to house } \\
\text { the controls. The controls were } \\
\text { designed to NUREG } 0700 \text { per DOE } \\
\text { Order } 6403 \text {. la guidance. The } \\
\text { trailer will also meet this } \\
\text { document. }\end{array}$ \\
\hline 9 & $\begin{array}{l}\text { sect } 2.2 .6 \text { All structures } \\
\text { and components that are } \\
\text { intended for installation and } \\
\text { removal via crane shall have } \\
\text { their weight permanently and } \\
\text { prominently marked on the } \\
\text { item and indicated on the } \\
\text { definitive design media. A1I } \\
\text { structures and components } \\
\text { that are intended for } \\
\text { hands-on installation and } \\
\text { removal (e.g., pit valve } \\
\text { handles, inspection port } \\
\text { plugs, etc.) shall have their } \\
\text { weight permanently and } \\
\text { prominently marked on the } \\
\text { item and indicated on the } \\
\text { definitive design media. }\end{array}$ & $P$ & In progress \\
\hline 10 & $\begin{array}{l}\text { sect } 2.2 .6 \text { The WRSS shall be } \\
\text { designed to comply with all } \\
\text { onsite packaging and shipping } \\
\text { requirements. The scope of } \\
\text { the activity shall include } \\
\text { features which facilitate } \\
\text { removal and disposal of the } \\
\text { waste retrieval equipment. }\end{array}$ & $Y$ & $\begin{array}{l}\text { See POC WHC-SO-TP-PDC-015 on } \\
\text { packaging. }\end{array}$ \\
\hline
\end{tabular}




\begin{tabular}{|c|c|c|c|}
\hline $\begin{array}{l}\text { Item } \\
\text { No. }\end{array}$ & Document and Requirement & $\begin{array}{l}\text { Comply } \\
Y \text { or } Y\end{array}$ & Remarks or Comments \\
\hline 11 & $\begin{array}{l}\text { sect } 3.1 \text { The instrument and } \\
\text { control system shall monitor } \\
\text { and control the facility } \\
\text { retrieval and transfer } \\
\text { options, HVAC, and support } \\
\text { systems to perform all } \\
\text { functions necessary to } \\
\text { retrieve the contents of the } \\
\text { tank and transport the } \\
\text { material to its new holding } \\
\text { facility. }\end{array}$ & $Y$ & $\begin{array}{l}\text { Ladder logic coupled with a } \\
\text { programmable logic controller, } \\
\text { monitor and control the process of } \\
\text { pulling an object out of the tank } \\
\text { into the bag. These operations are } \\
\text { remotely controlled and visually } \\
\text { observed by } 3 \text { CCTV cameras on the } \\
\text { receiver. All controls for the FR } \\
\text { are located in a trailer. }\end{array}$ \\
\hline 12 & $\begin{array}{l}\text { sect } 4.5 \text { Electrical } \\
\text { enclosures, junction boxes, } \\
\text { and pull boxes shall meet the } \\
\text { requirements of the } \\
\text { environment in which the } \\
\text { housings are installed. }\end{array}$ & $Y$ & $\begin{array}{l}\text { All boxes exposed to the } \\
\text { environment will be constructed } \\
\text { using NEMA } 4 \text { type enclosures. This } \\
\text { applies to box(s) on the new } \\
\text { trailer (see drawing } \mathrm{H}-2-78935 \text { ) and } \\
\text { actual hardware from the retrofit } \\
\text { grout trailer. }\end{array}$ \\
\hline 13 & $\begin{array}{l}\text { sect } 4.7 \text { General design } \\
\text { guidelines for energy } \\
\text { conservation shall comply } \\
\text { with the following sections } \\
\text { of DOE Order } 6430.1 \mathrm{~A} \text { : } \\
\text { - O110-12, "Energy } \\
\text { Conservation" } \\
\text { - 1595-10, "Energy Management } \\
\text { Systems" } \\
\text { - 1595-11, "Interior } \\
\text { Electrical Power and Lighting } \\
\text { Systems" } \\
\text { The design must include an } \\
\text { energy conservation report in } \\
\text { accordance with DOE Order } \\
6430.1 A \text {, Section O110-12.8. }\end{array}$ & Y & $\begin{array}{l}\text { No report will need to be written } \\
\text { per section } 0110-12.8 \text {. I We will } \\
\text { not exceed } 500 \text { million BTUs (total } \\
\text { energy consumption) per year nor is } \\
\text { the trailer(s) greater than } 10,000 \\
\text { sq ft. No full blown analysis will } \\
\text { be done. An agreement was made not } \\
\text { to do a big analysis per telephone } \\
\text { conversation and ce mail to Bill } \\
\text { White of DOE-RL and WHC Energy } \\
\text { Management. The agreement was to } \\
\text { write a DSI to file (DSI-94-DJT- } \\
\text { o01) showing why no further } \\
\text { analysis will need to be done on } \\
\text { project } 151 \text { trailer. There will } \\
\text { not be any more analysis done on } \\
\text { the trailer taken from grout since } \\
\text { its not changing the trailer } \\
\text { structure or its support equipment. }\end{array}$ \\
\hline
\end{tabular}




\begin{tabular}{|c|c|c|c|}
\hline $\begin{array}{l}\text { Item } \\
\text { No. }\end{array}$ & Document and Requirement & $\begin{array}{l}\text { Comply } \\
\text { Y or } N\end{array}$ & Remarks or Comments \\
\hline 14 & $\begin{array}{l}\text { sect } 4.8 .2 \text { Provisions for } \\
\text { remote replacement of system } \\
\text { equipment that operates in } a \\
\text { high-radiation zone shal1 } 1 \text { be } \\
\text { made as required to meet } \\
\text { ALARA criteria (see } \\
\text { DOE/EV/1830-T5, A Guide to } \\
\text { Reducing Radiation Exposure } \\
\text { to as Low as Reasonably } \\
\text { Achievab]e [ALARA] [DOE } \\
\text { 1980]). The capability shall } \\
\text { be provided to perform a } \\
\text { prel iminary decontamination, } \\
\text { where practical, of equipment } \\
\text { before repair or removal. }\end{array}$ & Y & $\begin{array}{l}\text { ALARA has been employed when } \\
\text { operating the equipment and when } \\
\text { placing it too. There are no } \\
\text { sources of exposure when placing } \\
\text { the receiver equipment with the } \\
\text { exception of possible airborne } \\
\text { contaminants from opening the } \\
\text { riser. Operation of the FR is } \\
\text { performed remotely in a trailer } \\
\text { away from the equipment being } \\
\text { removed (source of radiation). A } \\
\text { spray wash system has been } \\
\text { incorporated to partially } \\
\text { decontaminate the equipment to be } \\
\text { removed from the tanks. There is } \\
\text { adequate provision for } \\
\text { decontaminating the inside of the } \\
\text { receiver before removing. The } \\
\text { receiver has several access ports } \\
\text { which have the potential to be used } \\
\text { for decontaminating the internal } \\
\text { surfaces of the FR. }\end{array}$ \\
\hline 15 & $\begin{array}{l}\text { sect } 4.8 .2 \text { All mechanical } \\
\text { equipment, windows, cameras, } \\
\text { television monitors, and } \\
\text { other equipment in areas of } \\
\text { potential radioactivity } \\
\text { shall, where practical, be } \\
\text { sealed or otherwise protected } \\
\text { from penetration by } \\
\text { contamination and } \\
\text { decontamination solutions. }\end{array}$ & $Y$ & $\begin{array}{l}\text { All joints, unions, or access ports } \\
\text { that are exposed to the removed } \\
\text { equipment have seals. }\end{array}$ \\
\hline 16 & $\begin{array}{l}\text { sect } 4.8 .2 \text { All electrical } \\
\text { and instrumentation equipment } \\
\text { shall be properly grounded } \\
\text { for safety of personnel and } \\
\text { protection of equipment. }\end{array}$ & $Y$ & $\begin{array}{l}\text { A11 electrical equipment has been } \\
\text { designed per the NEC code. All } \\
\text { equipment has been properly } \\
\text { grounded. See } H-2-98937\end{array}$ \\
\hline
\end{tabular}




\begin{tabular}{|c|c|c|c|}
\hline $\begin{array}{l}\text { Item } \\
\text { No. }\end{array}$ & Document and Requirement & $\begin{array}{l}\text { Comply } \\
Y \text { or } N\end{array}$ & Remarks or Comments \\
\hline 17 & $\begin{array}{l}\text { sect } 4.8 .3 \text { Materials shall } \\
\text { be compatible with the } \\
\text { exposed environment. } \\
\text { Installed materials shall be } \\
\text { (1) resistant to radiation, } \\
\text { process solutions, acid and } \\
\text { caustic vapors and solutions, } \\
\text { and known decontamination } \\
\text { agents; (2) nonabsorbent, } \\
\text { easily removable if not } \\
\text { contamination resistant; } \\
\text { and/or ( } 3 \text { ) oversized to } \\
\text { permit partial destruction } \\
\text { without affecting structural } \\
\text { integrity. }\end{array}$ & $Y$ & $\begin{array}{l}\text { The environmental conditions that } \\
\text { receiver equipment material will be } \\
\text { exposed to is the following: 1) } \\
\text { normal desert weather, 2) hot } \\
\text { water, and } 3 \text { ) radiation. All } \\
\text { components exposed to the weather } \\
\text { are weather proofed. Critical } \\
\text { components, such as hydraulic } \\
\text { piping have been designed to } \\
\text { account for corrosion by being } \\
\text { fabricated from stainless steel } \\
\text { The interior of the receiver will } \\
\text { see the worst conditions which } \\
\text { includes the hot water and } \\
\text { radiation. All equipment exposed } \\
\text { to these conditions has been } \\
\text { designed to endure such an } \\
\text { environment. Note that radiation } \\
\text { levels may be high, but exposure } \\
\text { time is low, which precludes that } \\
\text { material that is normally not so } \\
\text { conducive to the radiation will } \\
\text { still be acceptable. Also, use of } \\
\text { the receiver equipment will be } \\
\text { limited, See drawing H-2-79310, } \\
79320,79362 \text { for parts lists. } \\
\end{array}$ \\
\hline 18 & $\begin{array}{l}\text { sect } 5.1 .2 \text { A safety } \\
\text { analysis shail be conducted } \\
\text { in accordance DOE Order } 5480 \\
\text { and } 6430 \text {. }\end{array}$ & $Y$ & $\begin{array}{l}\text { See WHC-SD-WM-PSE-010 for project } \\
\text { W320 and WHC-SD-W151-PSAR-001 for } \\
\text { W151. }\end{array}$ \\
\hline
\end{tabular}




\begin{tabular}{|c|c|c|c|}
\hline $\begin{array}{l}\text { Item } \\
\text { No. }\end{array}$ & Document and Requirement & $\begin{array}{l}\text { Comply } \\
Y \text { or } N\end{array}$ & Remarks or Comments \\
\hline 19 & $\begin{array}{l}\text { sect } 5.1 .3 \text { The retrieval } \\
\text { system shall be designed to } \\
\text { confine contaminants within } \\
\text { the combination of boundaries } \\
\text { defined by the existing tank, } \\
\text { the confinement surfaces of } \\
\text { the retrieval system, and any } \\
\text { other barriers that may be } \\
\text { required. A system shall be } \\
\text { employed to control } \\
\text { contamination caused by a } \\
\text { failure of the primary } \\
\text { confiner or other off-normal } \\
\text { situation. }\end{array}$ & $Y$ & $\begin{array}{l}\text { The tank ventilation system is a } \\
\text { method of contamination control } \\
\text { should a failure of the primary } \\
\text { confiner (open riser, or failed } \\
\text { Flexible Receiver bag) occur. The } \\
\text { draft Safety Assessment, WHC-SD-WM- } \\
\text { SAD-024, Rev. A (approval expected } \\
\text { by } 10 / 94 \text { ), states that dose } \\
\text { consequences due to an open riser } \\
\text { condition with a failed tank } \\
\text { ventilation system is within the } \\
\text { acceptance guidelines of WHC-CM- } 4- \\
46 \text { for a period of at least } 8 \text { hours } \\
\text { on tank C-106. }\end{array}$ \\
\hline 20 & $\begin{array}{l}\text { sect } 5.1 .3 \text { The retrieval } \\
\text { system shall have provisions } \\
\text { for safe and effective } \\
\text { decontamination (see } \\
\text { Section } 5.8 \text { ) The design of } \\
\text { the WRSS shall facilitate } \\
\text { decontamination so that the } \\
\text { facil ity can be } \\
\text { decommissioned at a future } \\
\text { date. Guidance for retrieval } \\
\text { equipment design to } \\
\text { facilitate eventual } \\
\text { decommissioning shall be } \\
\text { obtained from DoE Order } \\
4700.1 \text {, Project Management } \\
\text { system (DOE 1987); ANSI } \\
\text { N300-1975, Design Criteria } \\
\text { for Decommissioning of } \\
\text { Nuclear Fuel Reprocessing } \\
\text { Plants (ANSI 1975); and DoE } \\
\text { Order 6430.1A, General Design } \\
\text { Criteria, Sectiong 1300-11.2 } \\
\text { and 1321-7 (DOE 1989). }\end{array}$ & $Y$ & $\begin{array}{l}\text { The retrieval system will spray } \\
\text { down the equipment with } 150^{\circ} \mathrm{F} \text { hot } \\
\text { water at } 3000 \text { psi. All the } \\
\text { contaminated water will return to } \\
\text { the tank. Everything is sealed both } \\
\text { with a vacuum from the tank and } \\
\text { joints with waterproof seals. The } \\
\text { Flexible Receiver has several } \\
\text { access ports which, if needed, } \\
\text { provide the ability to } \\
\text { decontaminate its internal } \\
\text { surfaces. }\end{array}$ \\
\hline
\end{tabular}




\begin{tabular}{|c|c|c|c|}
\hline $\begin{array}{l}\text { Item } \\
\text { No. }\end{array}$ & Document and Requirement & $\begin{array}{l}\text { Comply } \\
\text { Y or } N\end{array}$ & Remarks or Comments \\
\hline 21 & $\begin{array}{l}\text { sect } 5.1 .6 \\
\text { systems in temporary } \\
\text { facilities provided by this } \\
\text { project, e.g., the sluicing } \\
\text { control room, shall be } \\
\text { designed to meet the } \\
\text { following applicable } \\
\text { requirements: } \\
\text { DOE/EV-0043, Standards on } \\
\text { Fire Protection for Portable } \\
\text { Structures (DOE 1979) }\end{array}$ & Y & $\begin{array}{l}\text { This section is applicable only to } \\
\text { the control trailer but is exempted } \\
\text { per Internal Memo TF520-MEM-94-002, } \\
\text { M. E. Manthei to D. E. Legare, } \\
\text { "Project W-151, Tank 101-AZ Waste } \\
\text { Retrieval System, Fire Suppression } \\
\text { for Flexible Receiver Control } \\
\text { Trailers," dated February 15, 1994; } \\
\text { and, DOE Letter 94-PRJ-045, R. W. } \\
\text { Brown, DOE, to President, WHC, } \\
\text { "Flexible Receiver Control Trailer, } \\
\text { Concurrence for Interpretation of } \\
\text { DOE Standard EV-0043, 'Standard on } \\
\text { Fire Protection for Portable } \\
\text { Structures', August 1979", dated } \\
\text { June 3, 1994 (distributed by CCRN } \\
\text { \#9403731). }\end{array}$ \\
\hline 22 & $\begin{array}{l}\text { sect } 5.1 .6 \\
\text { system shall be compatible } \\
\text { with, and tie into, the } \\
200 \text { Area Hanford Site radio } \\
\text { fire alarm system. }\end{array}$ & Y & $\begin{array}{l}\text { This section is applicable only to } \\
\text { the control trailer but is exempted } \\
\text { per Internal Memo 7F520-MEM-94-002, } \\
\text { M. E. Manthei to D. E. Legare, } \\
\text { "Project W-151, Tank 10I-AZ Waste } \\
\text { Retrieval System, Fire Suppression } \\
\text { for Flexible Receiver Control } \\
\text { Trailers," dated February 15, 1994; } \\
\text { and, DOE Letter 94-PRJ-045, R. W. } \\
\text { Brown, DOE, to President, WHC, } \\
\text { "Flexible Receiver Control Trailer, } \\
\text { Concurrence for Interpretation of } \\
\text { DoE Standard EV-O043, 'Standard on } \\
\text { Fire Protection for Portable } \\
\text { Structures', August 1979", dated } \\
\text { June 3, 1994 (distributed'by CCRN } \\
\text { \#9403731). }\end{array}$ \\
\hline
\end{tabular}




\begin{tabular}{|c|c|c|c|}
\hline $\begin{array}{l}\text { Item } \\
\text { No. }\end{array}$ & Document and Requirement & $\begin{array}{l}\text { Comply } \\
Y \text { or } N\end{array}$ & Remarks or Comments \\
\hline 23 & $\begin{array}{l}\text { sect } 5.4 .1 \text { Components and } \\
\text { structures of all systems } \\
\text { shall be designed for a OBE } \\
\text { as specified in HPS-SDC-4.1, } \\
\text { "Design Loads for Structures" } \\
\text { (DOE-RL 1988b), and DOE Order } \\
6430.1 A, \text { General Design } \\
\text { Criteria (DOE 1989), for } \\
\text { Safety Classes } 1,2,3, \text { and } \\
4 \text {. }\end{array}$ & $Y$ & $\begin{array}{l}\text { For the new trailer: Per H-2- } \\
78935 \text {, the trailer is purchased to } \\
\text { meet the requirements of SDC } 4.1 \text {. } \\
\text { For the retrofit trailer: This } \\
\text { trailer was designed and } \\
\text { constructed and reevaluated for SDC } \\
4.1 \text { per WHC-SD-WM-SA-089. } \\
\text { For the Flexible Receiver: This } \\
\text { has been designed for a } 70 \mathrm{MPH} \text { (UBC } \\
\text { requirement) wind and will } \\
\text { withstand it per WHC-SD-WI51-DA- } \\
\text { 003 All other factors (snow, } \\
\text { earthquake, ash) are not as severe } \\
\text { as wind so there was no need to } \\
\text { perform calculations. }\end{array}$ \\
\hline 24 & $\begin{array}{l}\text { sect } 5.4 .5 \\
\text { incorporate features that } \\
\text { maintain the WRSS and waste } \\
\text { tank in a safe condition if a } \\
\text { design basis power failure } \\
\text { occurs. Safety and health of } \\
\text { the public and onsite } \\
\text { personnel shall be key } \\
\text { considerations in the design. }\end{array}$ & $y$ & $\begin{array}{l}\text { An uninterruptible power supply is } \\
\text { provided for the Flexible Receiver } \\
\text { Control Panels with a generator for } \\
\text { backup power. This will maintain } \\
\text { equipment in a safe condition and } \\
\text { provide power for continuing } \\
\text { operation if a design basis power } \\
\text { failure occurs. }\end{array}$ \\
\hline 25 & $\begin{array}{l}\text { sect } 5.5 \text { Design shall } \\
\text { consider human factors for } \\
\text { maintenance and operations } \\
\text { activities, including } 2 \\
\text { control panel, equipment, } \\
\text { valve location and } \\
\text { orientation, secondary waste } \\
\text { handling, and facility } \\
\text { arrangement. The design } \\
\text { shall comply with DOE Order } \\
6430.1 \mathrm{~A} \text {, Section } 1300-12 \text {. }\end{array}$ & $\gamma$ & $\begin{array}{l}\text { This applies only to the controls } \\
\text { in the trailer which is being } \\
\text { constructed per NUREG 0700. The } \\
\text { compliance check list for NUREG } \\
0700 \text { was filled out on the basis of } \\
\text { this equipment and for both WI5l an } \\
\text { W320 trailers. Also, a system task } \\
\text { analysis of the operation was } \\
\text { performed to analyze operational } \\
\text { conditions and tasks. This process } \\
\text { will be continually evaluated } \\
\text { during the first several operations } \\
\text { so that we may improve those things } \\
\text { which play a hinderance in the } \\
\text { operation. }\end{array}$ \\
\hline
\end{tabular}




\begin{tabular}{|c|c|c|c|}
\hline $\begin{array}{l}\text { Item } \\
\text { No. }\end{array}$ & Document and Requirement & $\begin{array}{l}\text { Comply } \\
\text { Y or } N\end{array}$ & Remarks or Corments \\
\hline 26 & $\begin{array}{l}\text { sect } 5.8 \text { Modular, separable } \\
\text { confinements shall be used } \\
\text { for radioactive and other } \\
\text { hazardous materials to } \\
\text { preclude contamination of } \\
\text { fixed portions of the } \\
\text { structure. }\end{array}$ & Y & $\begin{array}{l}\text { Most if any contaminants on the } \\
\text { flexible receiver will be located } \\
\text { within the portion that equipment } \\
\text { is removed. Decontamination of } \\
\text { this should be feasible since the } \\
\text { material is stainless steel. Any } \\
\text { seams or joints exposed to the } \\
\text { removed equipment will also be a } \\
\text { suspect for collection. This } \\
\text { equipment (after being once used) } \\
\text { will undergo some decontamination } \\
\text { but will more than likely be } \\
\text { classified as radiated equipment } \\
\text { and treated as such throughout its } \\
\text { life. }\end{array}$ \\
\hline 27 & $\begin{array}{l}\text { sect } 5.8 \text { Surfaces should be } \\
\text { free of crevices, ledges, } \\
\text { and/or protrusions which } \\
\text { could collect radioactive } \\
\text { material. }\end{array}$ & Y & $\begin{array}{l}\text { Surfaces have been designed to } \\
\text { minimize the amount of crevices, } \\
\text { ledges, etc. }\end{array}$ \\
\hline 28 & $\begin{array}{l}\text { sect } 5.8 \text { Penetrations shall } \\
\text { be waterproofed for } \\
\text { protection during } \\
\text { decontamination efforts. }\end{array}$ & $Y$ & $\begin{array}{l}\text { All material exposed to both the } \\
\text { weather and the spray wash system } \\
\text { will be sealed to prevent any water } \\
\text { seepage. The primary and secondary } \\
\text { bags contain an absorbent (see H-2- } \\
79289 \text { ) to ensure no dripping } \\
\text { occurs. }\end{array}$ \\
\hline 29 & $\begin{array}{l}\text { sect } 5.8 \\
\text { outlets shall be sealed. }\end{array}$ & Y & See \# 15 remark. \\
\hline 30 & $\begin{array}{l}\text { sect } 5.8 \text { Adequate clearance } \\
\text { shall be provided for } \\
\text { transfer of equipment. }\end{array}$ & $\gamma$ & Work will be taking place outdoors. \\
\hline 31 & $\begin{array}{l}\text { sect } 5.8 \text { Lifting lugs shall } \\
\text { be used on large tanks or } \\
\text { equipment. }\end{array}$ & $\gamma$ & $\begin{array}{l}\text { There are several hoisting lifts on } \\
\text { various components of the receiver } \\
\text { For example, the bag assembly, the } \\
\text { whole receiver assembly, or just } \\
\text { the cutter assembly can all be } \\
\text { individually lifted up on their } \\
\text { own. This applies to both the } 42 " \\
\text { and the } 4^{\prime \prime}-6^{n} \text { receivers. }\end{array}$ \\
\hline
\end{tabular}




\begin{tabular}{|c|c|c|c|}
\hline $\begin{array}{l}\text { Item } \\
\text { No. }\end{array}$ & Document and Requirement & $\begin{array}{l}\text { Comply } \\
Y \text { or } N\end{array}$ & Remarks or Comments \\
\hline 32 & $\begin{array}{l}\text { sect } 5.8 \text { Modular radiation } \\
\text { shielding shall be used in } \\
\text { lieu of, or in addition to, } \\
\text { monolithic shielding walls. }\end{array}$ & $N / A$ & $\begin{array}{l}\text { This will be determined by the } \\
\text { Radiation Work Permit and is not } \\
\text { applicable to the qualification of } \\
\text { the receiver. }\end{array}$ \\
\hline 33 & $\begin{array}{l}\text { Drawings shall comply to the } \\
\text { standards listed in WHC-CM-6- } \\
3 \text {. }\end{array}$ & $Y$ & $\begin{array}{l}\text { All Flexible Receiver drawings have } \\
\text { been drawn to the standards listed } \\
\text { in the manual with the exception of } \\
\text { the vendor supplied drawings of } \\
\text { high pressure pump trailer and the } \\
\text { old grout trailer. }\end{array}$ \\
\hline \multicolumn{4}{|c|}{$\begin{array}{l}\text { The foll lowing requirements are taken from WHC-SD-W151-SORD-001, Supplemental } \\
\text { Design Requirements Document, 241-AZ-101 Waste Retrieval System. }\end{array}$} \\
\hline 34 & $\begin{array}{l}\text { 3.4.1.1 The Flexible } \\
\text { Receiver Assemblies shall be } \\
\text { designed to remove new and/or } \\
\text { existing profile and sludge } \\
\text { thermocouple trees; mixer } \\
\text { pumps and new/ existing } \\
\text { transfer pumps from the 101- } \\
\text { AZ tank. }\end{array}$ & $Y$ & $\begin{array}{l}\text { Drawings } H-2-79222 \text { and } H-2-79348 \\
\text { provide the Flexible Receiver } \\
\text { assemblies that will be used for } \\
\text { removing equipment from the 101-AZ } \\
\text { tank. }\end{array}$ \\
\hline 35 & $\begin{array}{l}\text { 3.4.1.2 Waste equipment } \\
\text { removed from the } 101-A Z \text { tank } \\
\text { will be placed into a sealed } \\
\text { flexible receiver for } \\
\text { containment of radioactive } \\
\text { and chemical contamination } \\
\text { during removal and transport. } \\
\text { The associated removal and } \\
\text { mounting equipment shall also } \\
\text { be designed to maintain } \\
\text { containment of radioactive } \\
\text { and chemical contamination } \\
\text { while equipment is being } \\
\text { removed from the tank. The } \\
\text { enclosure shall meet the } \\
\text { requirements of Radiological } \\
\text { Design, WHC-CM-4-9 and } \\
\text { Hanford Radioactive Solid } \\
\text { Waste Packaging, storage, and } \\
\text { Disposal Requirements, WHC- } \\
\text { EP-0063, Rev. } 3 \text {. }\end{array}$ & $Y$ & See Item $\# 10$ \\
\hline
\end{tabular}




\begin{tabular}{|c|c|c|c|}
\hline $\begin{array}{l}\text { Item } \\
\text { No. }\end{array}$ & Document and Requirement & $\begin{array}{l}\text { Comply } \\
Y \text { or } H\end{array}$ & Remarks or Comments \\
\hline 36 & $\begin{array}{l}\text { 3.4.1.3 Fire retardant } \\
\text { materials shall be used for } \\
\text { the flexible receiver } \\
\text { material. }\end{array}$ & Y & $\begin{array}{l}\text { The Flexible Receiver is } \\
\text { constructed of stainless steel and } \\
\text { a flexible bag which meets the fire } \\
\text { protection requirements of MIL-C- } \\
43006 \text { Type I. }\end{array}$ \\
\hline 37 & $\begin{array}{l}3.4 .1 .4 \text { The receiver shall, } \\
\text { as a goal, have a leak rate } \\
\text { of less than } 0.3 \text { volume } \\
\text { percent per hour, for a } 12- \\
\text { hour period, at an initial } \\
\text { negative pressure } \\
\text { differential of } 4 \text { inches of } \\
\text { water. After bagging is } \\
\text { completed, the solid waste } \\
\text { article shall be placed into } \\
\text { a trough or similar container } \\
\text { to prevent any leakage of } \\
\text { waste to the surrounding } \\
\text { soil. The bag is only } \\
\text { intended for contamination } \\
\text { control during removal. }\end{array}$ & Y & $\begin{array}{l}\text { The Flexible Receiver containment } \\
\text { is provided by impervious stainless } \\
\text { steel and receiver bags which are } \\
\text { leak tested to more stringent } \\
\text { criteria per } \mathrm{H}-2-79326 \text {. }\end{array}$ \\
\hline 38 & $\begin{array}{l}3.4 .1 .5 \text { Equipment will be } \\
\text { installed and removed using a } \\
\text { crane. }\end{array}$ & Y & $\begin{array}{l}\text { To be demonstrated in Qualification } \\
\text { Testing. }\end{array}$ \\
\hline 39 & $\begin{array}{l}\text { 3.4.1.6 Removal equipment } \\
\text { will require remote operation } \\
\text { from a distance to minimize } \\
\text { radiation exposure to } \\
\text { personnel. ALARA principles } \\
\text { shall be used at all times in } \\
\text { the design of the equipment. }\end{array}$ & Y & $\begin{array}{l}\text { Equipment operation is performed } \\
\text { from inside the control trailer at } \\
\text { a remote location. }\end{array}$ \\
\hline 40 & $\begin{array}{l}3.4 .1 .7 \text { Design of the } \\
\text { flexible receiver shall allow } \\
\text { recovery action for failed } \\
\text { in-tank riser components in } \\
\text { high radiation areas which } \\
\text { may include remote } \\
\text { reinsertion of components. }\end{array}$ & Y & $\begin{array}{l}\text { To be demonstrated in Qualification } \\
\text { Testing. }\end{array}$ \\
\hline
\end{tabular}




\begin{tabular}{|c|c|c|c|}
\hline $\begin{array}{l}\text { Item } \\
\text { No. }\end{array}$ & Document and Requirement & $\begin{array}{l}\text { Comply } \\
\text { Y or N }\end{array}$ & Remarks or Comments \\
\hline 41 & $\begin{array}{l}3.4 .1 .8 \text { Removal equipment } \\
\text { must be operable in ambient } \\
\text { conditions from } 35^{\circ} \mathrm{F} \text { to } \\
120^{\circ} \mathrm{F} \text {. Equipment will not be } \\
\text { used during high wind, rain } \\
\text { or freezing conditions. }\end{array}$ & $Y$ & $\begin{array}{l}\text { Equipment has been designed for } \\
\text { these conditions. }\end{array}$ \\
\hline 42 & $\begin{array}{l}\text { 3.4.1.9 The Flexible } \\
\text { Receiver Assembly will } \\
\text { interface with the wash } \\
\text { assembly (section } 3.4 .3 \text { ) on } \\
\text { the riser. }\end{array}$ & $Y$ & $\begin{array}{l}\text { To be demonstrated in Qualification } \\
\text { Testing. }\end{array}$ \\
\hline 43 & $\begin{array}{l}\text { 3.4.1.10 The lifting } \\
\text { mechanism hook speed shall } \\
\text { have a range of } 1-8 \mathrm{fpm} \text {. } \\
\text { Speed control shall be } \\
\text { obtained by modifying the } \\
\text { hydraulics of an existing } \\
\text { crane. The new speed control } \\
\text { system shall not eliminate or } \\
\text { reduce existing crane } \\
\text { capabilities. }\end{array}$ & $Y$ & $\begin{array}{l}\text { This requirement is provided by the } \\
\text { "Specification for Modification to } \\
\text { Grove Crane at 1100" V-W151-0003. }\end{array}$ \\
\hline 44 & $\begin{array}{l}\text { 3.4.1.11 Hook speed, } \\
\text { position indicator, and hook } \\
\text { load with associated readout } \\
\text { (located in crane cab) shall } \\
\text { be provided for the existing } \\
\text { site crane. The equipment } \\
\text { mounted on the crane shall be } \\
\text { weatherproof. }\end{array}$ & $Y$ & $\begin{array}{l}\text { This requirement is provided by the } \\
\text { "Specification for Modification to } \\
\text { Grove Crane at 1100" V-W151-0003. }\end{array}$ \\
\hline 45 & $\begin{array}{l}\text { 3.4.1.12 Total weight of the } \\
\text { new components (to be lifted } \\
\text { as a unit) and the rigging } \\
\text { shall be within the capacity } \\
\text { of existing site cranes. }\end{array}$ & $Y$ & \\
\hline
\end{tabular}




\begin{tabular}{|c|c|c|c|}
\hline $\begin{array}{l}\text { Item } \\
\text { No. }\end{array}$ & Document and Requirement & $\begin{array}{l}\text { Comply } \\
Y \text { or } N\end{array}$ & Remarks or Comments \\
\hline 46 & $\begin{array}{l}\text { 3.4.1.13 A secondary } \\
\text { receiver bag assembly will be } \\
\text { secured around the bottom of } \\
\text { the primary flexible receiver } \\
\text { to contain residual } \\
\text { contamination between the } \\
\text { bottom of the primary } \\
\text { receiver bag and the cable } \\
\text { seal An absorbent material } \\
\text { will be placed in the bag to } \\
\text { absorb any liquid that may be } \\
\text { present. }\end{array}$ & Y & $\begin{array}{l}\text { Provided by the Flexible Receiver } \\
\text { Leak Containment Bag/Stand } \\
\text { Assemblies, H-2-79297 and } \\
\text { H-2-79362. Their function will be } \\
\text { demonstrated in Qualification } \\
\text { Testing. }\end{array}$ \\
\hline \multicolumn{4}{|c|}{ Spray Wash System, High Pressure Pump } \\
\hline 47 & $\begin{array}{l}3.4 .2 .1 \text { Hot water shall be } \\
\text { furnished on site from the } \\
200 \text { Area boiler plant. The } \\
200^{\circ} \mathrm{F} \text { maximum water will be } \\
\text { tanker trucked to } 101-A Z \text {. }\end{array}$ & Y & $\begin{array}{l}\text { To be demonstrated in Qualification } \\
\text { Testing. }\end{array}$ \\
\hline 48 & $\begin{array}{l}\text { 3.4.2.2 The high pressure } \\
\text { spray wash system supply } \\
\text { shall have an operating } \\
\text { discharge pressure of } 3000 \\
\text { psi and will be designed and } \\
\text { fabricated per ASME B31.1, as } \\
\text { applicable. }\end{array}$ & y & $\begin{array}{l}\text { This requirement is provided by } \\
\text { "Procurement Specification for High } \\
\text { Pressure Hot Water System", } \\
\text { WHC-S-037 and documented in CVI } \\
\text { file } 22515 \text {. }\end{array}$ \\
\hline 49 & $\begin{array}{l}\text { 3.4.2.3 The portable high } \\
\text { pressure spray wash system } \\
\text { shall be totally enclosed } \\
\text { and/or weather proof to the } \\
\text { extent possible, except for } \\
\text { the areas open for venting } \\
\text { and connectors. }\end{array}$ & Y & $\begin{array}{l}\text { This requirement is provided by } \\
\text { "Procurement Specification for High } \\
\text { Pressure Hot Water System", } \\
\text { WHC-S-037 and documented in CVI } \\
\text { file } 22515 \text {. }\end{array}$ \\
\hline 50 & $\begin{array}{l}\text { 3.4.2.4 The spray wash } \\
\text { system shall have a relief } \\
\text { valve, unloader or vent } \\
\text { system such that there is no } \\
\text { possibility of over } \\
\text { pressurization of the system. }\end{array}$ & $Y$ & $\begin{array}{l}\text { This requirement is provided by } \\
\text { "Procurement Specification for High } \\
\text { Pressure Hot Water System", } \\
\text { WHC-S-037 and documented in CVI } \\
\text { file } 22515 \text {. }\end{array}$ \\
\hline
\end{tabular}


Reference-

WHC-SD-W320-TIS-001 Rev 2

November 4, 1994

Page 16

\begin{tabular}{|c|c|c|c|}
\hline $\begin{array}{l}\text { Item } \\
\text { No. }\end{array}$ & Document and Requirement & $\begin{array}{l}\text { Comply } \\
Y \text { or } N\end{array}$ & Remarks or Corments \\
\hline 51 & $\begin{array}{l}\text { 3.4.2.5 The spray wash } \\
\text { system piping shall be } \\
\text { insulated with a moisture } \\
\text { resistant material. }\end{array}$ & $Y$ & $\begin{array}{l}\text { Spray wash system piping is not } \\
\text { insulated and does not need to be. } \\
\text { Adequate guards are in place to } \\
\text { protect personnel from high } \\
\text { temperature piping. This } \\
\text { requirement will be revised to } \\
\text { reflect the accepted condition of } \\
\text { the piping prior to its field use } \\
\text { for either project } W-151 \text { or } W-320 \text {. }\end{array}$ \\
\hline 52 & $\begin{array}{l}\text { 3.4.2.6 All piping or hoses } \\
\text { associated with the hot water } \\
\text { supply shall also have } \\
\text { sufficient protection for the } \\
\text { safety of operating } \\
\text { personnel. }\end{array}$ & $\gamma$ & $\begin{array}{l}\text { This requirement is provided by } \\
\text { "Procurement Specification for High } \\
\text { Pressure Hot Water System", WHC-S- } \\
\text { 037 and documented in CVI file } \\
22515 \text {. Flexible hoses will also be } \\
\text { administrativiely controlled to } \\
\text { protect personnel. }\end{array}$ \\
\hline 53 & $\begin{array}{l}\text { 3.4.2.7 The system shall be } \\
\text { mounted on a highway rated } \\
\text { Department of Transportation } \\
\text { approved trailer. The } \\
\text { trailer shall be suitable for } \\
\text { travel over loose gravel. }\end{array}$ & $\gamma$ & $\begin{array}{l}\text { This requirement is provided by } \\
\text { "Procurement Specification for High } \\
\text { Pressure Hot Water System", WHC-S- } \\
037 \text { and documented in CVI file } \\
22515 \text {. }\end{array}$ \\
\hline 54 & $\begin{array}{l}3.4 .2 .8 \text { A replaceable or } \\
\text { flushable filter shall be } \\
\text { provided for the water supply } \\
\text { with a capacity of up to } 50 \\
\text { gpm to prevent plugging of } \\
\text { the washer spray nozzles. }\end{array}$ & $Y$ & $\begin{array}{l}\text { Inlet water filter is provided. See } \\
\text { CVI file } 22515 \text {. }\end{array}$ \\
\hline 55 & $\begin{array}{l}\text { 3.4.2.9 The design shall } \\
\text { include a flexible discharge } \\
\text { supply hose capable of safely } \\
\text { handling the } 300 \text { psi hot } \\
\text { water being pumped to the } \\
\text { high pressure spray header } \\
\text { over a distance of } 200 \text { feet. }\end{array}$ & $Y$ & $\begin{array}{l}\text { This requirement is provided by } \\
\text { "Procurement Specification for High } \\
\text { Pressure Hot Water System", WHC-S- } \\
037 \text { and documented in CVI file } \\
22515 \text {. }\end{array}$ \\
\hline
\end{tabular}




\begin{tabular}{|c|c|c|c|}
\hline $\begin{array}{l}\text { Item } \\
\text { No. }\end{array}$ & Document and Requirement & $\begin{array}{l}\text { Comply } \\
Y \text { or } N\end{array}$ & Remarks or Comments \\
\hline 56 & $\begin{array}{l}\text { 3.4.2.10 Necessary valving, } \\
\text { piping, remote controls and } \\
\text { other instrumentation shall } \\
\text { be supplied as required. The } \\
\text { high pressure spray system } \\
\text { will be operated by either a } \\
\text { gasoline/diesel motor or } \\
\text { electric motor and come } \\
\text { complete with remote controls } \\
\text { and all necessary safety } \\
\text { features. }\end{array}$ & $Y$ & $\begin{array}{l}\text { This requirement is provided by } \\
\text { "Procurement Specification for High } \\
\text { Pressure Hot Water System", WHC-S- } \\
037 \text { and documented in CVI file } \\
22515 \text {. }\end{array}$ \\
\hline 57 & $\begin{array}{l}3.4 .2 .11 \text { The spray system } \\
\text { shall be capable of } \\
\text { delivering between } 20 \text { and } 50 \\
\text { gpm at } 3000 \text { psig, suitable } \\
\text { for both the } 4 / 6^{\prime \prime} \text { and the } 42^{\prime \prime} \\
\text { spray ring assemblies. }\end{array}$ & $Y$ & $\begin{array}{l}\text { This requirement is documented in } \\
\text { the CVI file } 22515 \text {. }\end{array}$ \\
\hline \multicolumn{4}{|c|}{ Decontamination Wash Assemblies } \\
\hline 58 & $\begin{array}{l}3.4 .3 .1 \text { Hardware removed } \\
\text { from tank } 101-A Z \text { will have } \\
\text { supernate/sludge washed from } \\
\text { the external and internal } \\
\text { surfaces during the equipment } \\
\text { removal process using the } \\
\text { spray wash system. }\end{array}$ & Y & $\begin{array}{l}\text { The washing hardware is depicted on } \\
\text { drawing H-2-79256 "TWRS 101-AZ } \\
\text { Washer Assembly". }\end{array}$ \\
\hline 59 & $\begin{array}{l}3.4 .3 .2 \text { Wash equipment } \\
\text { should be designed for } \\
\text { cleaning hardware, with } \\
\text { complete circumference } \\
\text { coverage, at a nominal } \\
\text { vertical removal rate of one } \\
\text { foot per minute. }\end{array}$ & Y & $\begin{array}{l}\text { The washing hardware is depicted on } \\
\text { drawing H-2-79256 "TWRS 101-AZ } \\
\text { Washer Assembly". }\end{array}$ \\
\hline
\end{tabular}




\begin{tabular}{|c|l|c|c|}
\hline $\begin{array}{c}\text { Item } \\
\text { No. }\end{array}$ & Document and Requirement & $\begin{array}{l}\text { Comply } \\
\text { Y or N }\end{array}$ & \multicolumn{1}{|c|}{ Remarks or Comments } \\
\hline 60 & $\begin{array}{l}3.4 .3 .3 \text { Nozzles with a flat } \\
\text { spray configuration and an } \\
\text { operating pressure of 3000 } \\
\text { psi shall be used in the } \\
\text { washer assembly. Nozzles } \\
\text { shall be orientated such that } \\
\text { both top and bottom sides of } \\
\text { protrusions on the removed } \\
\text { components exterior are } \\
\text { thoroughly rinsed, in } \\
\text { addition to the yertical } \\
\text { surfaces. }\end{array}$ & $Y$ & $\begin{array}{l}\text { The washing hardware is depicted on } \\
\text { drawing H-2-79256 "WWS 101-AZ } \\
\text { Washer Assembiy". }\end{array}$ \\
\hline 61 & $\begin{array}{l}\text { 3.4.3.4 The 4/6" spray ring } \\
\text { shail be sized for 20-25 gpm } \\
\text { flow rate at 3000 psig.. The } \\
42 " \text { spray ring shal1 be sized } \\
\text { for 40-50 gpm flow rate at } \\
3000 \text { psig. }\end{array}$ & $Y$ & $\begin{array}{l}\text { The washing hardware is depicted on } \\
\text { drawing H-2-79256 "TWRS 101-AZ } \\
\text { Washer Assembly". }\end{array}$ \\
\hline
\end{tabular}




\begin{tabular}{|c|c|c|c|}
\hline $\begin{array}{l}\text { Item } \\
\text { No. }\end{array}$ & Document and Requirement & $\begin{array}{l}\text { Comply } \\
Y \text { or } N\end{array}$ & Remarks or Comments \\
\hline 62 & $\begin{array}{l}\text { 3.4.5.1 Trailer } \\
\text { a. Provide environmentally } \\
\text { controlled trailer housing } \\
\text { instrumentation, electrical } \\
\text { control equipment, operators, } \\
\text { monitors, vCRs, displays and } \\
\text { recording equipment. Trailer } \\
\text { shall house Instrumentation } \\
\text { and Control (I\&C) equipment } \\
\text { for the flexible receiver, } \\
\text { washer, and radiation } \\
\text { monitoring. } \\
\text { b. All suitable I\&C } \\
\text { equipment shall be installed } \\
\text { in. I9 inch racks to the } \\
\text { extent possible. } \\
\text { c. All cables and wiring } \\
\text { inside of the trailer shall } \\
\text { conform to the requirements } \\
\text { NFPA-70. } \\
\text { d. Trailer shall have smoke } \\
\text { detection with audible alarm. } \\
\text { e. Maximum power to the } \\
\text { trailer shall be limited to } \\
440 \text { vaC, } 3 \text { phase. } \\
\text { f. Trailer shall have } \\
\text { personnel exits at opposite } \\
\text { ends of the traller which } \\
\text { open from the inside. Rear } \\
\text { cargo doors do not count as } \\
\text { exits. }\end{array}$ & $\begin{array}{l}Y \\
Y \\
Y \\
Y\end{array}$ & $\begin{array}{l}\text { The Flexible Receiver Control } \\
\text { Trailer is depicted on drawing } \\
\text { H-2-78935, "W151 - TWRS Trailer } \\
\text { Assemb1y". }\end{array}$ \\
\hline
\end{tabular}




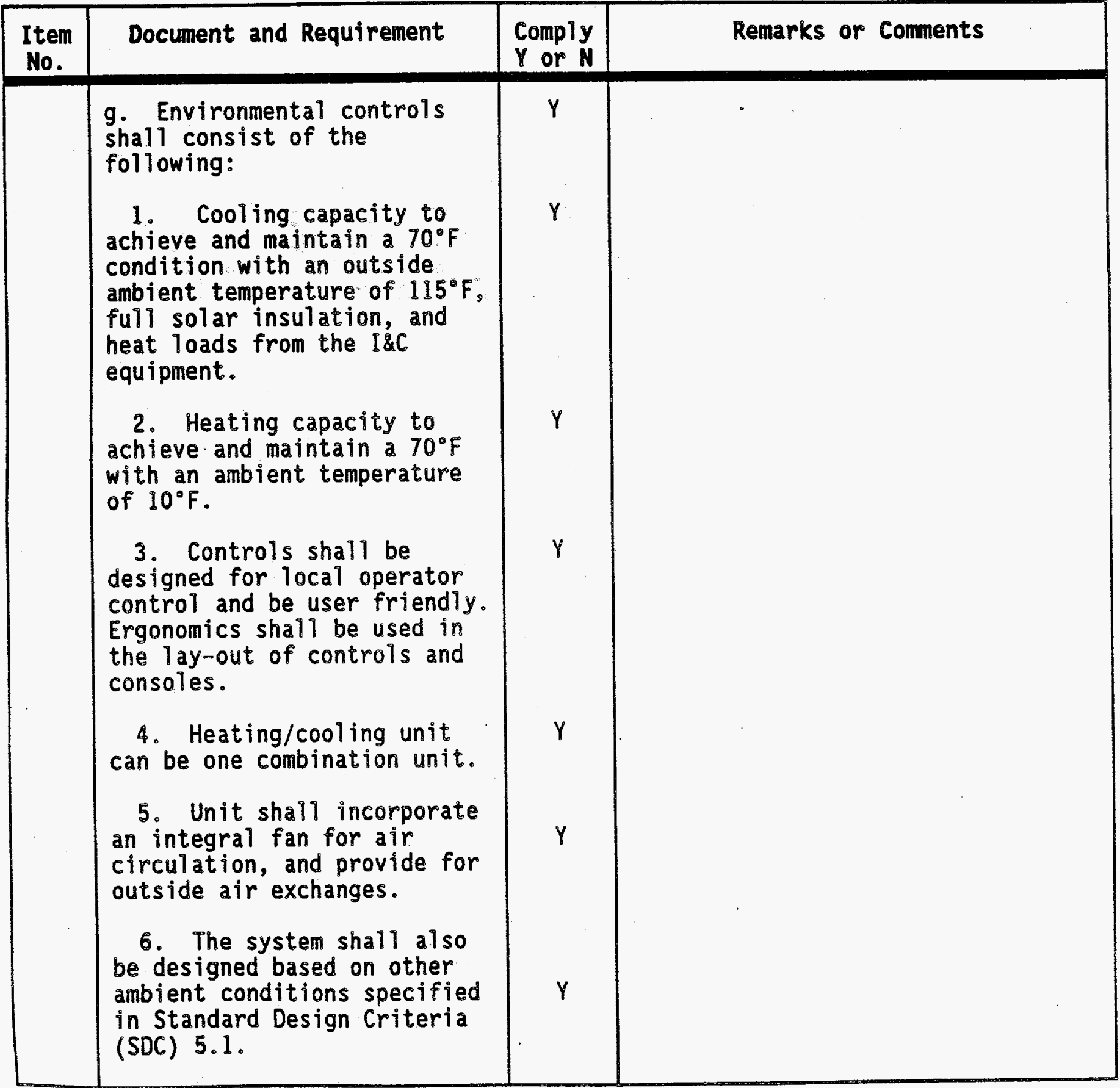




\begin{tabular}{|c|c|c|c|}
\hline $\begin{array}{l}\text { Item } \\
\text { No. }\end{array}$ & Document and Requirement & $\begin{array}{l}\text { Comply } \\
\text { Y or N }\end{array}$ & Remarks or Comments \\
\hline 63 & $\begin{array}{l}3.4 .5 .2 \text { Flexible Receiver } \\
\text { Control Console (FRCC) } \\
\text { a. The FRCC shall control } \\
\text { the operation of the Flexible } \\
\text { Receiver, including the } \\
\text { thermocouple liquid removal } \\
\text { tool, in a manually actuated } \\
\text { sequence (controller forces } \\
\text { operator to a fixed sequence) } \\
\text { with manual emergency } \\
\text { override controls available } \\
\text { to secure the operation in a } \\
\text { safe configuration. } \\
\text { b. The sequence, interlocks } \\
\text { and indicating lights shall } \\
\text { be provided for equipment } \\
\text { operation. } \\
\text { c. FRCC shall be located in } \\
\text { the trailer described in } \\
\text { 3.4.5.l. } \\
\text { d. Parameters shall be } \\
\text { displayed in engineering } \\
\text { units. } \\
\text { e. Three CCTV monitors and } \\
\text { cameras shall be provided to } \\
\text { monitor field operations. } \\
\text { f. Operators shall be able } \\
\text { to, through a front panel } \\
\text { select or on a multiplexer, } \\
\text { view any camera on any } \\
\text { monitor. }\end{array}$ & $Y$ & $\begin{array}{l}\text { To be demonstrated in Qualification } \\
\text { Testing. }\end{array}$ \\
\hline
\end{tabular}




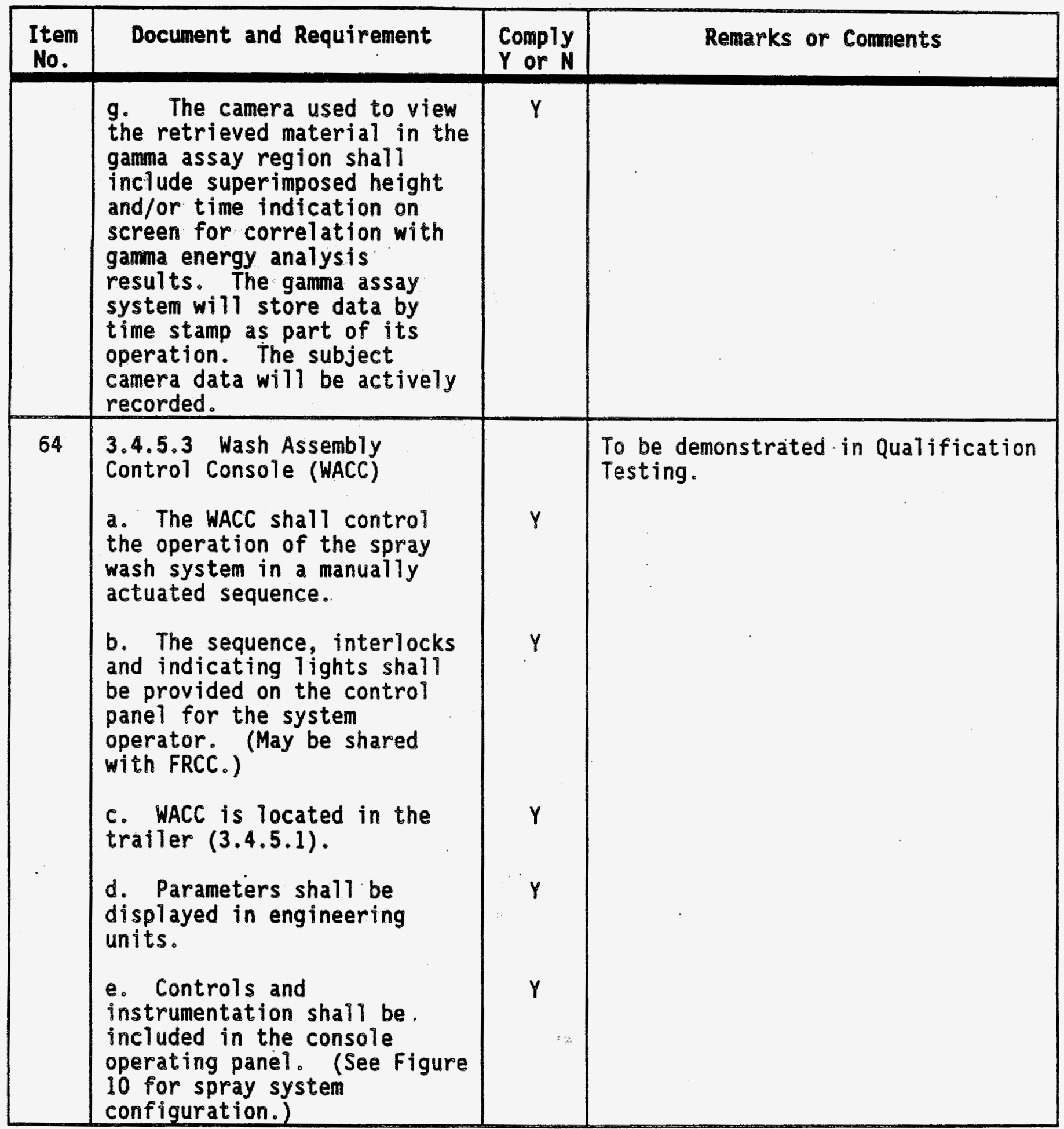




\begin{tabular}{|c|c|c|c|}
\hline $\begin{array}{l}\text { Item } \\
\text { No. }\end{array}$ & Document and Requirement & $\begin{array}{l}\text { Compiy } \\
Y \text { or } N\end{array}$ & Remarks or Corments \\
\hline 65 & $\begin{array}{l}\text { 3.4.5.4 Radiation Monitoring } \\
\text { Control Console } \\
\text { Radiation monitoring controls } \\
\text { (computer data acquisition) } \\
\text { and readout shall be } \\
\text { installed in 19" racks (to } \\
\text { the extent practical) with } \\
\text { other control equipment in } \\
\text { the } A Z \text { tank farm control } \\
\text { room. }\end{array}$ & $Y$ & $\begin{array}{l}\text { See drawing H-2-78931 "TWRS Control } \\
\text { Console". }\end{array}$ \\
\hline 66 & $\begin{array}{l}\text { 3.4.5.5 Electrical System } \\
\text { a. The electrical system in } \\
\text { the trailer shall convert the } \\
\text { supplied } 440 \text { VAC, } 3 \text { phase as } \\
\text { necessary for use by the } \\
\text { instrumentation, electrical \& } \\
\text { control equipment, monitors, } \\
\text { displays and recording } \\
\text { equipment, lighting and } \\
\text { environmental equipment. } \\
\text { b. The installation shall be } \\
\text { per the latest edition of the } \\
\text { National Electric Code (NFPA } \\
\text { 70). }\end{array}$ & $Y$ & $\begin{array}{l}\text { The Flexible Receiver Control } \\
\text { Trailer is depicted on Drawing H- } \\
\text { 2-78935, "W151 - TWRS Trailer } \\
\text { Assembly". }\end{array}$ \\
\hline
\end{tabular}




\section{PART II - DESIGN VERIFICATION BY OPERATIONAL TESTING}

\subsection{TEST ITEM IDENTIFICATION}

The Flexible Receiver (FR) is a remotely operated device to remove equipment contaminated with radioactive and hazardous waste from buried tanks or below-ground installations with minimal exposure to the operating personnel and no release of contamination to the environment. This equipment will be attached to a pipe flange or plate at the top of the proposed removed equipment. The Flexible Receiver will wash the equipment off as it is being removed, check for the amount of radiation on the equipment, insert the equipment in a fabricated bag, and seal the equipment in this bag for disposal or storage.

Al1 of the controls of the equipment are located in a trailer with interlocks on each of the control switches so that accidental operation of equipment can't happen without the prior proper sequence of operations being performed.

Figure 1 shows a breakdown of the equipment by systems. There are two types of receivers; one that can remove equipment from a 42 " diameter riser (see Figure 2) and this is referred to as the $42^{\prime \prime}$, and the second one can remove equipment from 4" and 6" diameter risers (see Figure 3 ) and is referred to as the 4"-6" Flexible Receiver. The Flexible Receiver systems are described on drawings $\mathrm{H}-2-79336$ for the $4^{\prime \prime}-6^{11}$ Flexible Receiver and $\mathrm{H}-2-79342$ for the 42" Flexible Receiver.

NOTE: The GAMMA ASSAY SYSTEM will not be tested by this document but has been tested per WHC-SD-W151-ATP-001.

\subsection{FLEXIBLE RECEIVER SYSTEMS}

FLEXIBLE RECEIVER BAG AND CARTRIDGE ASSY

FLEXIBLE RECEIYER TOP ASSY

\section{CCTY CAMERAS}

GAMMA ASSAY SYSTEM AND SPOOL ASSY
- Frame and special bag that equipment is pulled up and into.

- Assembly that closes the bottom of the bag. cinches the wire rope cables, cuts the cables and cuts the bag between the sealed sections of the bag.

- Used to remotely view operation

- Monitors radiation of equipment being pulled out, provides access to the inside of the spool assembly and is the mounting for internal cameras. 
SPRAY WASH

SECONDARY BAG ASSY
- Sprays down equipment being extracted.

- Acts as secondary bag over the end of the primary bag that was cut. 
Reference

WHC-SD-W320-TIS-001 ReV 2

November 4, 1994

Page 26

Figure 1. Flexible Receiver Systems

\section{FLEXIBLE RECEIVER SYSTEMS}

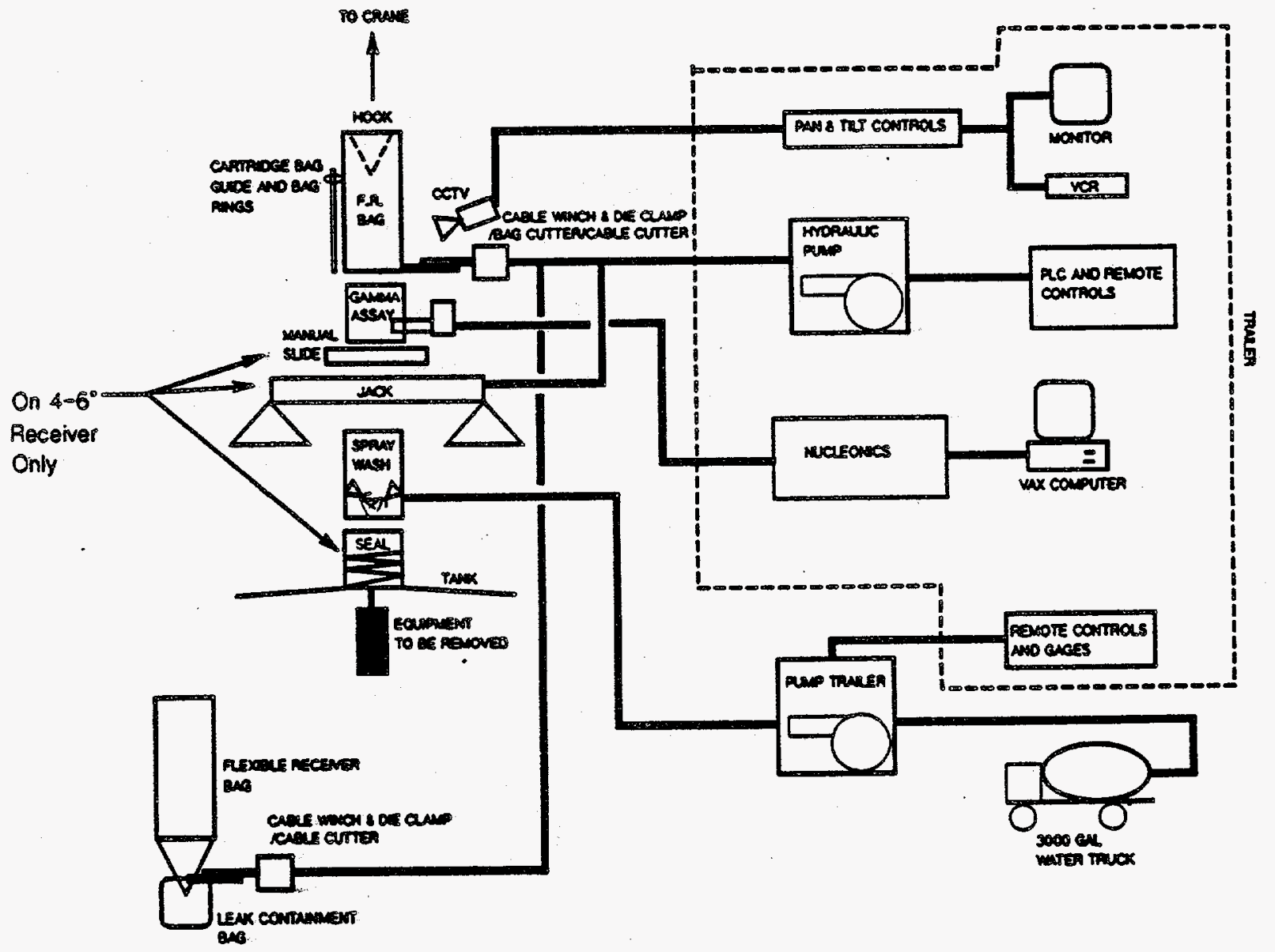


Reference-

WHC-SD-W320-TIS-001 ReV 2

November 4, 1994

Page 27

Figure 2. Typical 42" Flexible Receiver Located On A Tank

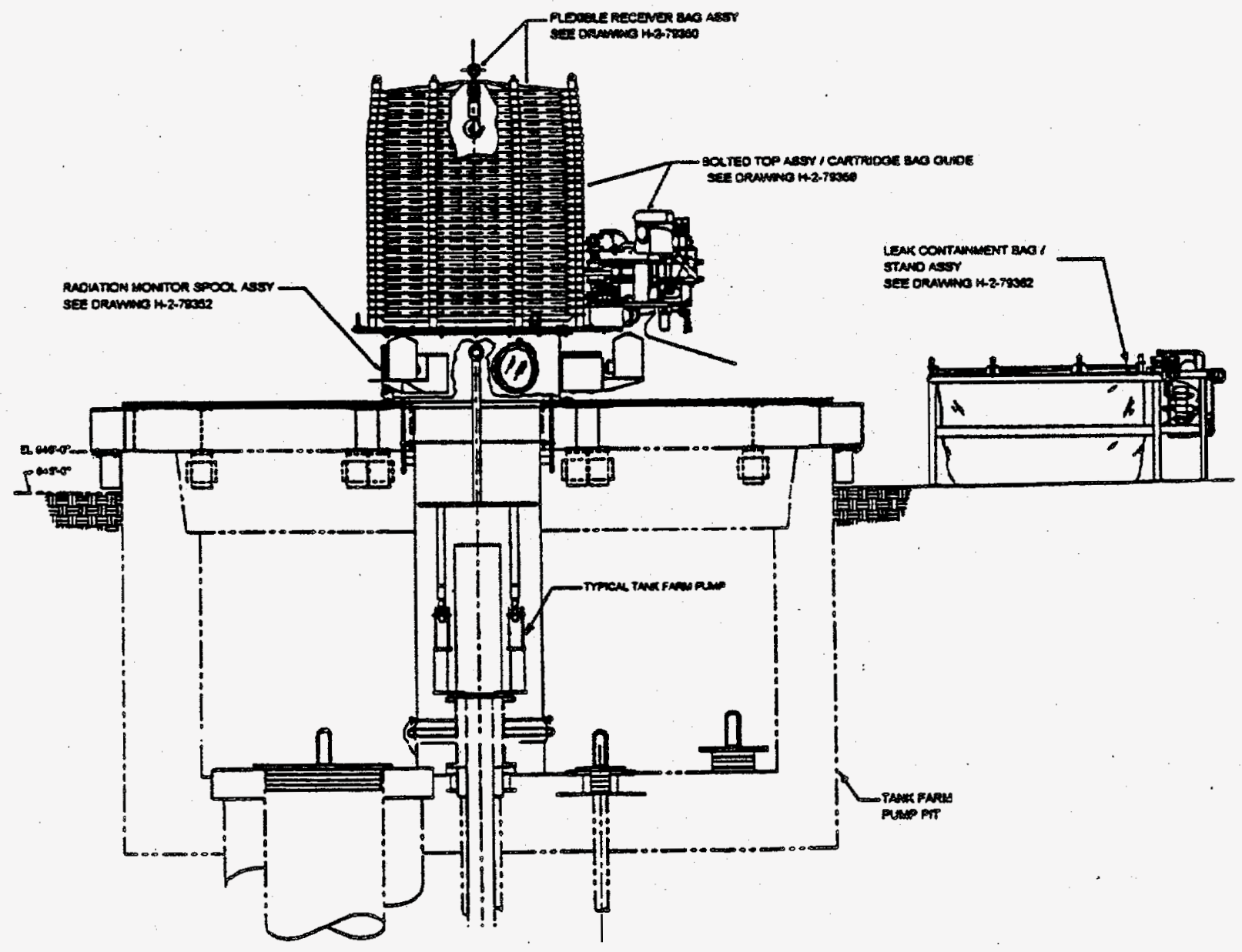


Reference-

WHC-SD-W320-TIS -001 ReV 2

- November 4, 1994

Page 28

Figure 3. Typical 4"-6" Flexible Receiver Located On A Tank

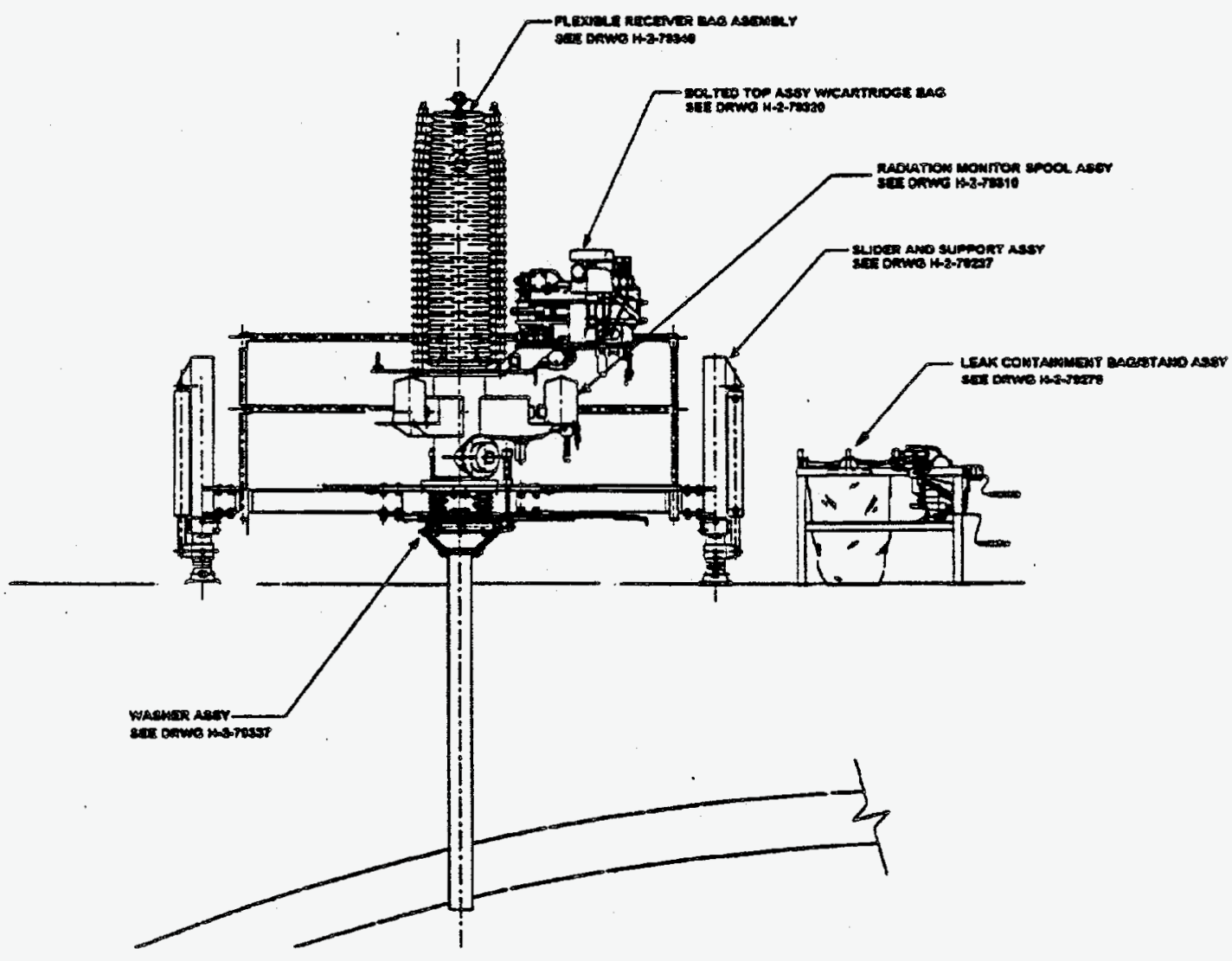




\subsection{GENERAL DESCRIPTION}

\subsection{TEST OBJECTIVES}

The objective of this test is to qualify the design of the $42^{\prime \prime}$ and $4 "-6$ " Flexible Receiver systems for field use by demonstrating environmentally safe removal of a Tank Farm pump mock-up from a Tank Farm riser mock-up. Testing will al so demonstrate the performance of supporting equipment.

The Flexible Receiver and the Secondary Bagging equipment shall be tested to verify successful operation of the equipment to the following criteria:

a. The Flexible Receiver can be placed on a riser and connections made to the supporting equipment.

b. The Flexible Receiver bag can accept equipment and be successfully sealed.

c. The Secondary Bagging System encases the seal of the primary Flexible Receiver bag.

d. The flexible bag(s) do not tear and maintain integrity during the entire test.

e. The FR control system operates in the fail safe forced sequence mode.

f. The FR control system will operate in the manual override mode (out of sequence operations).

g. The CCTV Video system monitors and records the removal of the test item.

$h$. The spray wash system operates without leaks and effectively provides coverage (4"-6" only).

i. The item being removed can be reinserted to a depth of 8 feet and the bag reinstalled onto the vertical bag supports.

j. The system prohibits momentary mechanical fluctuations due to the application of system power, including power interruptions.

\subsection{TEST CONDITION LIMITS}

\subsection{OPERATIONAL LIMITS}

No unique or unusual industrial, radiological, chemical, or critical safety hazards are involved with performance of this test. 
Testing will be stopped due to any safety concern, equipment failure, or at the discretion of the Test Director. Resumption of testing will continue when the concerns have been addressed and/or repairs have been completed to the satisfaction of the Test Director.

\subsection{ENVIRONMENTAL LIMITS}

The crane pulling operation beginning with step 8.3 .2 .11 shall NOT begin if the wind velocity exceeds $10 \mathrm{MPH}$. If the pulling operation has begun and the weather changes for the worse, testing shall be stopped and the test equipment secured so that no damage will be incurred.

\subsection{FACILITIES, EQUIPMENT, AND MATERIALS}

\subsection{TEST FACILITY}

Testing will be performed at the cold Test Facility, located west of Route 4 on Route 11A between the 200 East and 200 west Areas. The Cold Test Facility

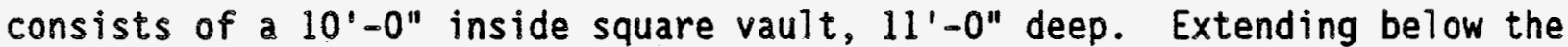
bottom of the vault floor is a $6^{\prime}-0^{\prime \prime}$ diameter caisson $53^{\prime}-0^{\prime \prime}$ deep.

As an option portions of this test may be performed at the Equipment Testing Laboratory ( $305 \mathrm{Bldg})$, or other suitable facility.

\subsection{EQUIPMENT}

- The on-site modified 110 Ton "GROVE" crane or equal.

- A vacuum system that will simulate the negative pressure within the waste tank. Vacuum pressure is equal to or greater then 0.25 inches of water but will not exceed 2 inches of water during operation.

- Electrical power for the Flexible Receiver control trailer and pump truck $480 \mathrm{~V} 3 \mathrm{PH} 60 \mathrm{HZ}$ and 200 Amps for control trailer and 200 Amps for the HPS pump trailer.

- $\quad 3000$ gallon water truck filled with water to $150-175^{\circ} \mathrm{F}$

- The high pressure spray trailer

- The $42^{11}$ or $4^{n-}-6^{\prime \prime}$ Flexible Receiver

- The $42^{\prime \prime}$ or $4^{\prime \prime}-6^{\prime \prime}$ Secondary Bagger

- A 70 foot long Flexibie Receiver bag for the $42^{\prime \prime}$ or $4^{\prime \prime}-6$ " FR

- A $42^{18}$ secondary bag for the $42^{\prime \prime}$ or $4^{\prime \prime-6 " ~ F R ~}$

- A simulated process pump and thermocouple 
- Control trailer with hydraulic pump, control racks, video systems, etc

- Emergency pole for placing rings on FR poles when lowering the receiver bag.

- Stop watch

- Spare components, such as test bags, cabling, and cable sleeves that will be expended during testing.

- Safety equipment: hard hat, leather gloves, safety glasses, steel toed shoes

- Replacement bulbs for control panel lights.

- 3 VHS tapes (minimum)

- PLC accessories

\subsection{SAFETY}

NOTE: THE INFORMATION IN THIS SECTION SHALL BE TOLD TO ALL PERSONNEL IN OR AROUND THE TEST AREA BEFORE TESTING BEGINS. SAFETY IS THE RESPONSIBILITY OF ALL INDIVIDUALS. ALL CONCERNS SHOULD BE DIRECTED TO THE TEST DIRECTOR OR APPOINTEE.

Hazards associated with the job are found in the Preliminary Safety Evaluation (WHC-SD-WM-PSE-010) with the exception of the radiological hazards which will not apply to this test. Potential hazards are: over head objects (crane), tripping (wires and hoses on the ground), pinch points, and exposed 3000 psig high pressure $150^{\circ} \mathrm{F}$ hot water and hydraulic lines. All personnel within the crane operating zone will wear safety glasses, a hard hat, and steel toed shoes. Individuals working on or near the high pressure pump trailer/or its hoses are advised to wear hearing protection, a hard hat, safety glasses, and leather gloves when operating.

The test area will be kept free from nonessential personnel as directed by the Test Director. Individuals shall perform their assigned tasks in a safe manner so as to protect themselves and others from hazards and prevent damage to the property and the environment. The Test Director shall assure the safety of activities within their areas to prevent injury, property damage, or interruption of operation.

Crane operations shall be in accordance with the "Hanford Site Hoisting and Rigging Manual", (DOE-RL-92-36).

\subsection{EXCEPTIONS}


Exceptions to the test results will be sequentially numbered, recorded, and approved on individual Exception forms. If changes to the procedure are required during testing those changes will also be documented on an Exception Form. All exception forms will have written approval by the Test Director and Quality Assurance prior to the conclusion of testing. Whenever possible, exceptions will be approved at the time they are prepared. If required personnel are not available for approval at the time the exception is prepared then testing will be allowed to continue. Exception approval to continue testing may be written, verbal, or per telecon.

\subsection{PERSONNEL REQUIREMENTS}

\subsection{GENERAL}

Each organization participating in this test will designate personnel to assume the responsibilities and duties as defined herein for their respective roles. The designated personnel shall become familiar with this procedure and systems involved to the extent that they can perform their assigned duties.

\subsection{TEST DIRECTOR}

- Coordinates and directs testing.

- Acts as liaison between the participants in testing.

- Distributes the testing schedule within one week before start of testing.

- Schedules and conducts a pretest meeting with test participants before start of testing when necessary.

- Notifies the persons performing and witnessing the test 2 days before the start of testing.

- Schedules an informal test (dry run) when necessary.

- Notifies concerned parties when a change is made in the testing schedule.

- Takes necessary steps to clear exceptions to the test.

- Confirms that inspection of the system to be tested has been completed.

- Stops any test which, in the judgement of the director, may cause damage to the system or result in an Unsafe Condition.

- After verifying there is no adverse impact, may alter the sequence in which system or subsystems are tested, but not the sequence of 
steps in each test.

- Ensures that environmental conditions are maintained.

- If a test is to be suspended for a period of time, ensures that the system is left in a safe mode.

- Before restarting a suspended test, reverifies the test prerequisites.

- Reviews recorded data, discrepancies, and exceptions.

- Obtains information or changes necessary to clear or resolve objections during the performance of the test.

- Signs Exception Test and Approval page when test has been performed.

- Signs Exception form when exception has been resolved.

- Obtains required approval signatures for the final test report.

- Makes sure exceptions are incorporated into this document via ECN at completion of job.

\subsection{NITNESSES}

(Provided by Participating Organizations)

Observers, user representatives, and witnesses shall be notified 2 days prior to testing.

- Witness the tests and provide input while considering operation under actual tank farm conditions.

- Review results of testing.

- Assist the Test Director when required.

- Sign Execution and Test Approval page when test has been performed.

- Sign Exception form when exception has been resolved.

\subsection{RECOROER}

- Records names of all designated personnel prior to the start of testing.

- Records test instrument identification numbers and calibration expiration dates. 
- Observes tests and records test data.

- Signs Execution and Test Approval page.

- Initials and dates test steps as they are completed. On data sheets where there is not room for both the initial and date, the data may be added at the bottom of the column .

- Records exceptions on the Exception form.

- Signs Exception form when exception has been resolved.

- Notifies the Test Director at the time an objection is made.

- After the test is completed, assigns alpha numeric page numbers to added data sheets and Exception forms. Records page numbers in the Table of Contents.

\subsection{TEST OPERATOR}

- Performs test under direction of the Test Director.

- Provides labor, equipment, and test instruments required for performing tests.

- Confirms that all equipment required for performing test will be available at the start of testing.

- Signs the Execution and Test Approval page.

\subsection{QUALITY ASSURANCE WITNESS}

- Witnesses test steps are performed.

- Signs and approves test and exceptions.

\subsection{COG ENGINEER}

- Main Technical consultant on equipment

\subsection{TEST PROCEDURE}

\footnotetext{
NOTE: This procedure applies to the $42^{n}$ flexible receiver only. The procedure for testing the $4^{\prime \prime}-6^{\prime \prime}$ flexible receiver will be added in later (TBD5).
}

\section{I GENERAL SYSTEM REQUIREMENTS}

Cables and pipes are all connected per the FR drawings. The system 
permissive includes electrical verification that the control cable(s) have been installed.

A manual operation (i.e. operator actuate a switch) is required prior to starting or continuing operation after power is applied to the controller.

Operator must manually push, twist, or turn button(s) to control the sequence for the FR assembly and Secondary Bagger equipment. The control sequence for the Flexible Receiver assembly and Secondary Bagger equipment is implemented by a manually actuated, forced sequence of events; $i . e$. the operator manualiy pushes the button for the next step in the sequence while the controller ignores any input from the operator that is out of sequence.

Operator may use a "manual control" key operated switch to by-pass the normal system interlocks and permissive (under the procedural permission of the Test Director or assigned person-in-charge) in order to deal with an unusual situation.

\subsection{TEST CONDITIONS}

The following items shall be performed prior to other steps of this procedure.

\section{Initial/Date}

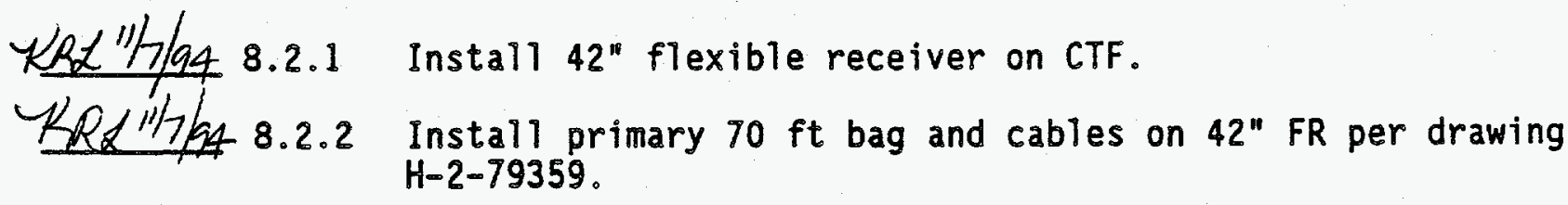

Kp $11 / 464$ 8.2.3 Install secondary bag and cable on leak container bag assembly.

Yef $11 / 7948.2 .4$ Flexible receiver assembly has been properly attached to the Cold Test Facility per $\mathrm{H}-2-79218$ and/or $\mathrm{H}-2-79219$ and/or $\mathrm{H}-$ 2-79220 and/or $\mathrm{H}-2-79221$ and support equipment (secondary bagger, control trailer, and high pressure water pump trailer and water truck (if applicable). Ensure hook swivel is attached to the pump lifting device. Note attachment of FR may require the use of the hydraul ic jacks (ONLY on $4^{\prime \prime}-6$ " FR) which would require operation of the hydraulic pump in the control trailer (Use steps in 8.3 OPERATIONAL SEQUENCE, 8.3.1 START UP SEQUENCE, to operate pump).

\section{$K_{R_{R}} 11 / 1 / 94-8.2 .5$}

All systems being tested have their hoses, piping, and electrical instrumentation and power properly connected per FR drawings.

8.2.6 Power is OFF to components of systems being tested. 
- Switch DS1 "MAIN POWER" is off.

- Switch DS2 "HYDRAULIC PWR UNIT" is off.

- Switch DS3 "TI TRANSFORMER" is off.

- Switch DS4 "HYD POWER UNIT" is off.

All test instruments have a valid calibration stamp attached.

$4 R_{2} 11 / 94$

Personnel responsible for directing and witnessing the performance of the tests described in this QTP have read and understand the operation of the equipment to be tested.

All personnel involved in, or witnessing, testing have met the safety requirements listed in section 5.0.

\subsection{OPERATIONAL SEQUENCE}

The following describes the sequence of events the Flexible Receiver Programmable Logic Controller (PLC) performs in conjunction with the operator(s) actions, and Secondary Bagger equipment. The control logic has 3 major parts: 1) Start up and initial conditions, 2) Operations performed by the Flexible Receiver, and 3) Operations performed by the Secondary Bagger.

The sequence of events are as follows: 1) Start up of equipment; 2) pull equipment out; 3) pull bag tight with cable; 4) clamp cable; 5) cut bag; 6) cut cable; 7) move bagged equipment to secondary bagger; 8) pull secondary bag tight with cable; 9) clamp cable; 10) cut cable.

If power is unexpectediy lost, the system shuts down and stops as is. Upon restoration of power, the "RESET" button is pressed and the system resumes operation at the step it was last performing before loss of power. This will be tested during the bagging operation.

\subsubsection{Start Up Sequence}

WARNING: Turning the HYDRAULIC POWER UNIT key switch, or the START SEQUENCE key switch to OFF, or loss of cable continuity at anytime will deenergize the master system permissive (internal coil 202). The controller will not permit any further actions until corrected.

The following is to be performed on the control panels ir the trailer.

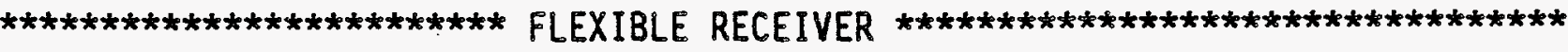
KRR $11 / 7 / 94$ 8.3.1.1 Section 8.2 has been completed.

8.3.1.2 Verify all switches located on the Flexible Receiver and High Pressure Spray control panels are in the OFF 


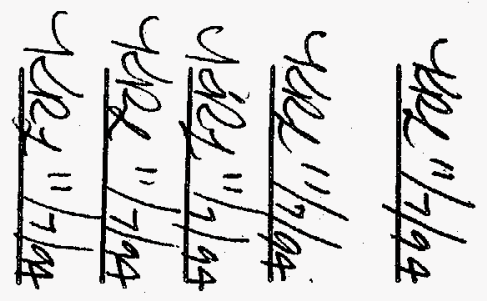

$\begin{array}{llllll}\infty & \infty & \infty & \infty & \infty\end{array}$

is is is is is

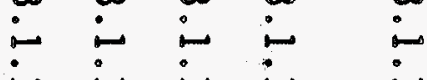

के जै

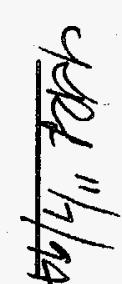

$\infty$

is

:

$\varpi$

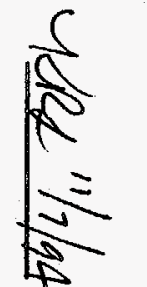

$\infty$

w

$\vdots$
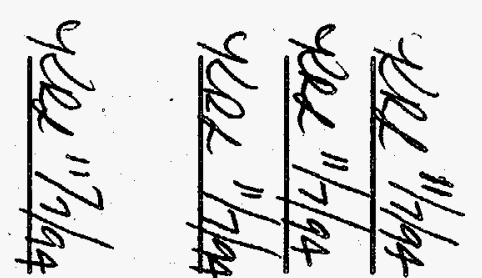

$\infty \infty \infty$

is $\omega$ w

im $\quad$ in

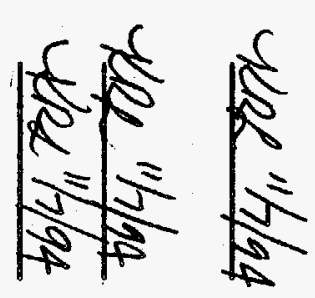

$\infty \infty$

is $\omega \omega$

in is
范市式

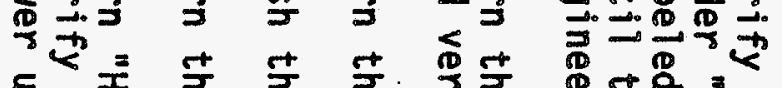

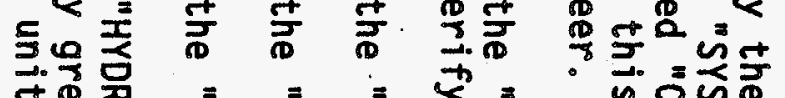

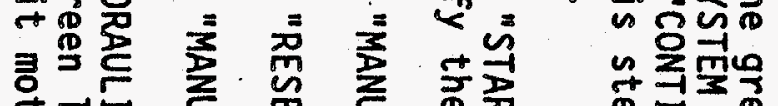

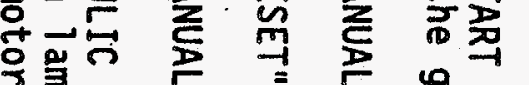

点

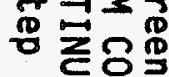

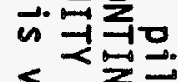

的表 욤 蛋穴灵

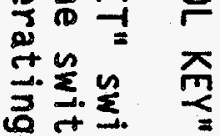
递窎 $\leq \vec{s}+$ 空 赵 تُ 象竞 กั

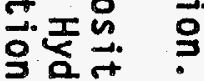

帘

ลำ

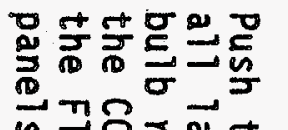

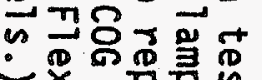
完。잉

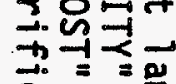

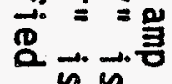

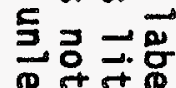

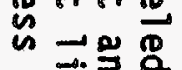
물 جั่ 웅믈 品了宓 प्+设 응훙무요 오윰웅ㅇㅇ

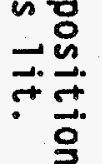
重寻的䛠 兽 可施总

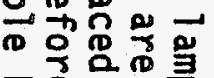

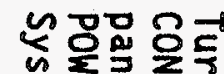

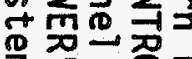
등ㅇㅁㄲ

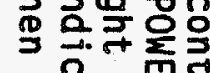
一业赑 政

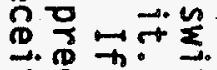

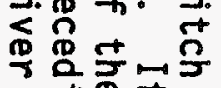
两为 苂苛 $\overrightarrow{\mathrm{g}}$

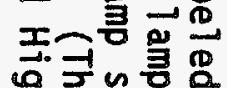

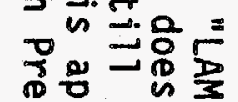
密安的

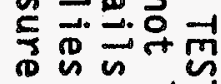

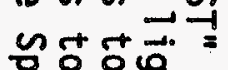

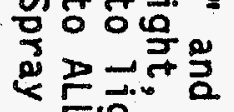

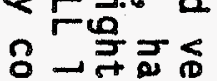

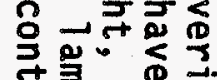

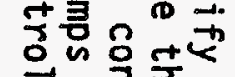
空察 जि융

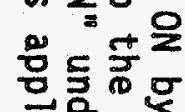

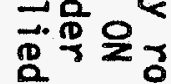

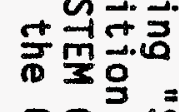

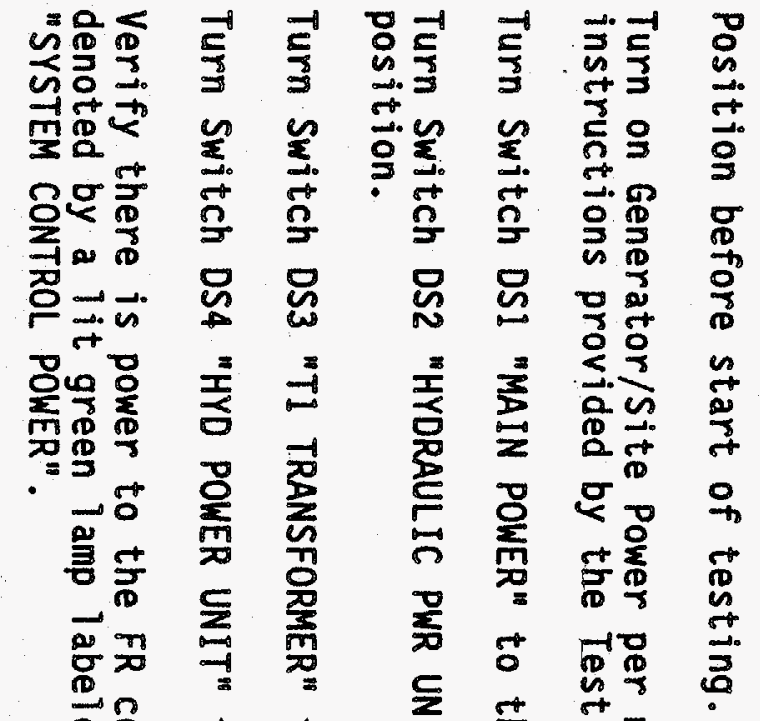

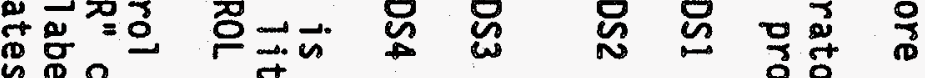
क $\frac{\infty}{\pi} \delta$

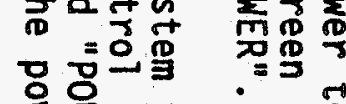

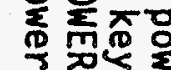

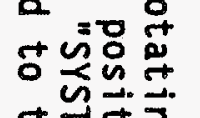
ㅇํㅇำ
超导 $=\frac{2}{2}+\frac{2}{2}$

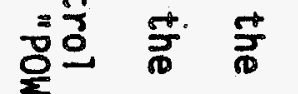
离祭 悥 윢 


\section{Yhe $11 / 7$ ga} YUR

Ylek $11 / 7 / 94$

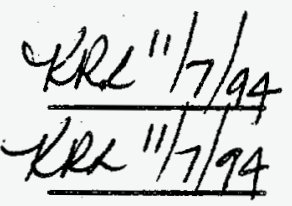

Verify "SYSTEM HYDRAULIC PRESSURE" panel meter is reading $0 \pm 100$ (psig).

Verify pressure gages on hydraulic pump in trailer, cable cutter, bag cutter, cable tie clamp, winch motors, jacks on the receiver unit, bellows separator (only on the 4"$6^{n}$ FR), and secondary cable tie clamp and winch motor read $0 \pm 100$ psig or has a blank meter screen. Only the meters associated with a function that is currently being used will show a pressure reading. If the meter reads 100 or greater before the starting that sequence, contact COG before proceeding.

Verify hydraulic connections are not leaking. If piping requires tightening, then turn "HYDRAULIC PWR UNIT" switch to the "OFF" position and resolve leak. Restart system by repeating steps 8.3.1.9? - 8.3.1.12.?

Turn "HYDRAULIC PWR UNIT" switch to the "OFF" position.

Remove the crane hook from the eyebolt of the FR bag. Raise the crane hook at a constant rate provided by the Test Director. Record the rate displayed at the FR Control Panel "CRANE HOIST ELEVATION RATE (feet per minute)" meter and the rate displayed at the crane. Verify that the displayed values are consistent.

Rate at Crane: $\mathrm{ft} / \mathrm{min}$

Rate at FR Trailer: $8.5-9.4 \mathrm{ft} / \mathrm{min}$

\section{CAMERA MONITORING}

Kp $11 / 7 / 94$

8.3.1.22 YLR'/7/948.3.1.23

KR $11 / 7 / 948.3 .1 .24$ YRd $1 / 7 / 948.3 .1 .25$ Yet "T/at 8.3.1.26 Turn on the Pan Tilt power. controller. is iit.

Under each monitor, ensure none of the buttons 1-8 are selected by being it or by being depressed.

Under monitor \#3, flip the "POWER" switches on camera control units 1 through 5 to the "ON" position and verify the green lights labeled "POWER" is lit for each

Turn on VCR's 1 through 3 by pressing "POWER" button and ensure the "POWER" light for each is on.

Turn on the "SONY" Video monitors by pushing in the "POWER" button and verify that the green light for each 
1LE"11/798 8.3.1.28

1ef $1 / 7 / 94$
Select camera's 1 through 3 for monitors 1 through 3 by pushing the appropriate button under each monitor.

8.3 .1 .27

Move the switch from the "OFF" position to "VERTICAL" position on the time/date generators 1-3 and verify time and date are displayed on each monitor.

8.3.1.29 Set the time and date according to the manufacturers manual if date/time isn't correct.

NOTE: ON CAMERAS

Adjustments to picture can be made by adjusting either the camera controls such as the "IRIS" or "WHITE BALANCE" or adjusting the monitor controls. If adjustments to these are not sufficient in giving a clear picture, then contact the Test Director or COG engineer.

Adjustments are not part of this testing but can be accomplished through use of the manufacture's operating manual.

\subsubsection{Flexible Receiver Sequence}

NOTE:

The following steps are to be performed in the order presented.

$* * * * * * * * * * * * * * * * * * * * * * * * * * * * * * * *$ CAMERA MONITORING

The following test will use Table 2 to describe the flexible receiver cameras being tested and their features. It also includes what they are viewing.

Table 2. Flexible Receiver Camera Features

\begin{tabular}{|c|c|c|c|c|}
\hline \multirow[b]{2}{*}{ Camera } & \multicolumn{3}{|c|}{ OPTIONS } & \multirow[b]{2}{*}{ View } \\
\hline & Zoom & Pan \& Tilt & Lights & \\
\hline 1 & NO & NO & YES & $\begin{array}{l}\text { Receiver spool and equipment } \\
\text { being removed. }\end{array}$ \\
\hline 2 & NO & YES & NO & $\begin{array}{l}\text { Hydraulic gauges and top assembly } \\
\text { on Receiver. }\end{array}$ \\
\hline 3 & NO & YES & NO & $\begin{array}{l}\text { Hydraulic gauges and top assembly } \\
\text { on Receiver. }\end{array}$ \\
\hline 4 & YES & YES & NO & $\begin{array}{l}\text { Overall view of Receiver located } \\
\text { on trailer. }\end{array}$ \\
\hline 5 & YES & YES & NO & Crane operations (optional) \\
\hline
\end{tabular}



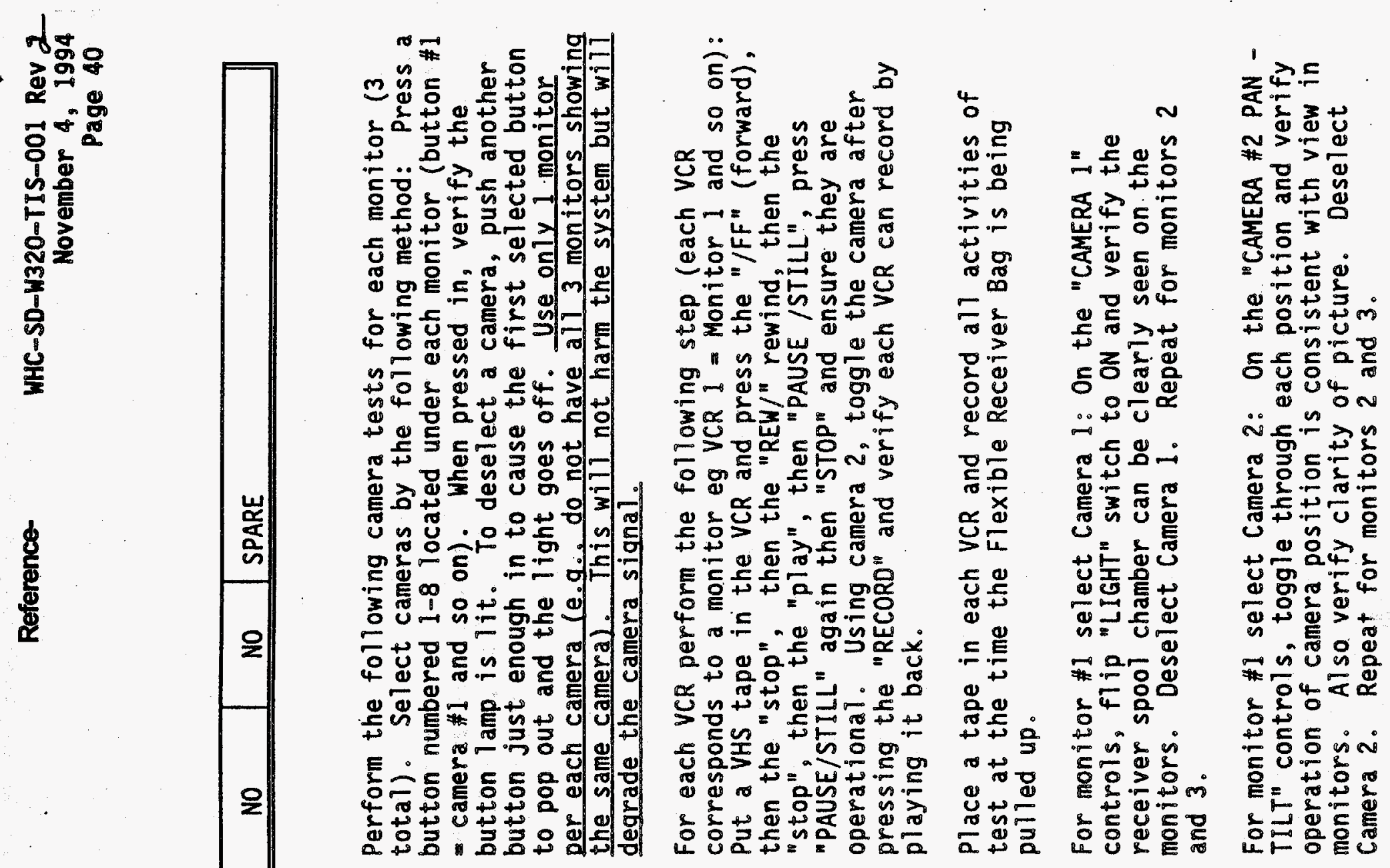

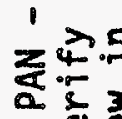

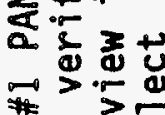

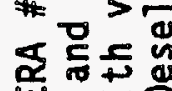

崖要

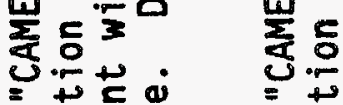

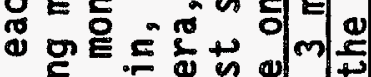

出和和

ㅁำ

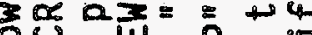

政的

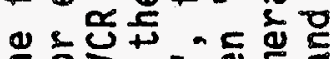

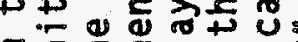

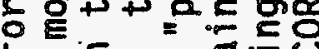

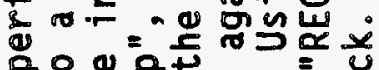

م

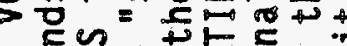

प्व

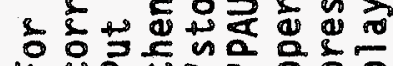

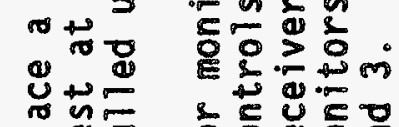

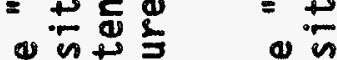

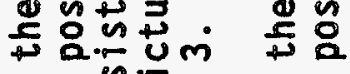

동듄단듀

.

$\ddot{m}=\ldots$

$\ddot{+}=$

๙

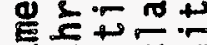

c

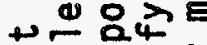

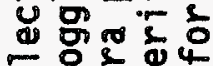

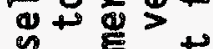

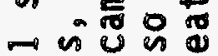

*

吉蓄

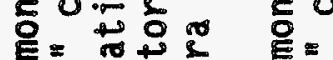

政要

䑻

空

$+\stackrel{\infty}{\circ}$

क

果
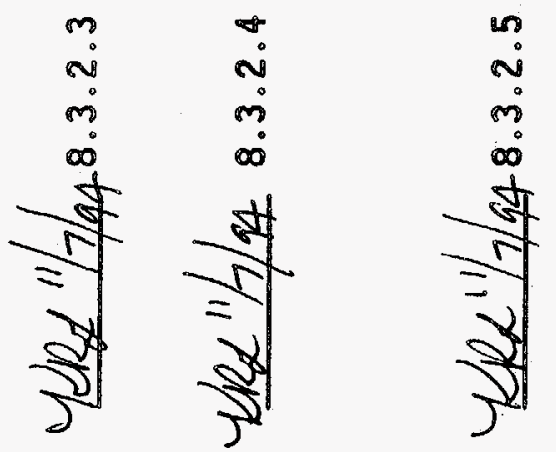

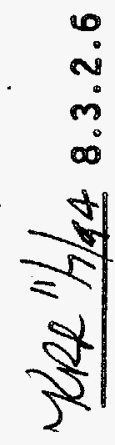

2
0
0
0
0
2
2
2
2 


\section{ERe"17g48.3.2.8 Yef 117 /94
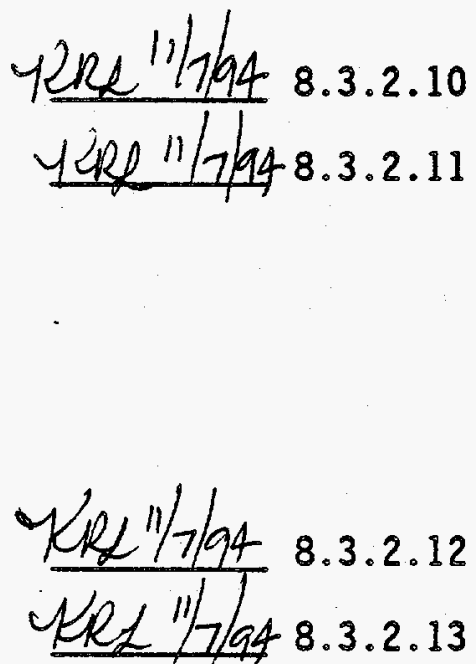

\subsubsection{2} 8.3.2.13 Y11R $11 / 7 / 94^{8.3 .2 .14}$ taking the cable from the camera control unit 5 and connect it to camera control unit 4.

operation of camera position is consistent with view in monitors. Also verify clarity of picture. On "CAMERA 4" controls,. operate flip "ZOOM" switch between "TELE" and "WIDE" and verify the TELE position gives a close view and a WIDE gives a wide view. Deselect Camera 4. Repeat for monitors 2 and 3.

Turn off power to camera control units 4 and 5 .

Use camera 4 with camera control unit 5 by taking the cable from the camera control unit 4 and connect it to camera control unit 5.

Turn on power to camera control units 4 and 5 .

For monitor \#1 select Camera 5: On the "CAMERA \#3 PAN TILT" controls, toggle through each position and verify operation of camera position is consistent with view in monitors. Also verify clarity of picture. On "CAMERA 5" controls flip the "ZOOM" switch between "TELE" and "WIDE" and verify the TELE position gives a close view and the WIDE position gives a wide view. Deselect camera 5 . Repeat for monitors 2 and 3.

Turn off power to camera control units 4 and 5 .

Return use the camera 4 to camera control unit 4 by connect it to camera control unit a.

Turn on power to camera control units 4 and 5.

Note: Camera control unit 6 is a spare and does not provide a video signal.

NOTE: ON CAMERAS

Use cameras throughout the test to visually inspect the operation unless called out in the procedure to field-verify. If cameras are unable to sufficientiy monitor the operation, then document problem and inform $C O G$ engineer.

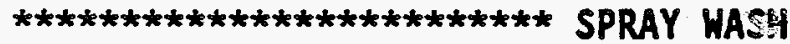

$120,11 / 7 / 64$

8.3.2.15

Hel" 1174.

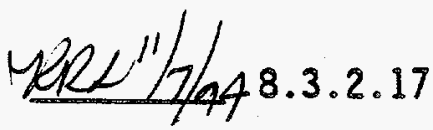

Turn on vacuum blower motor.

Turn main power disconnect switch on the High Pressure Spray System (HPSS) Pump Trailer to "ON".

Verify the green "SYSTEM POWER OFF" indicator light is illuminated on the HPSS Control Panel located in the FR 
$42 e^{11 / 7 / 948.3 .2 .18}$

Kee $1 / 7 / 94$

8.3.2.19

Yee $1 / 7 / 948.3 .2 .20$

$4 k 211 / 7 / 948$

8.3 .2 .21

YRR $11 / 7 / 948.3 .2 .22$
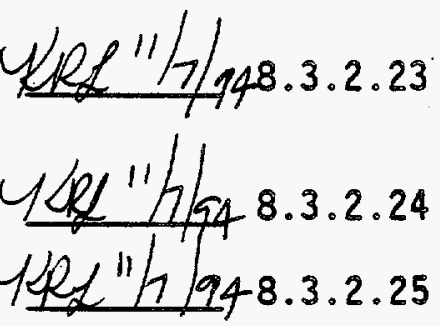

Yef $n / 7 / 948.3 .2 .26$

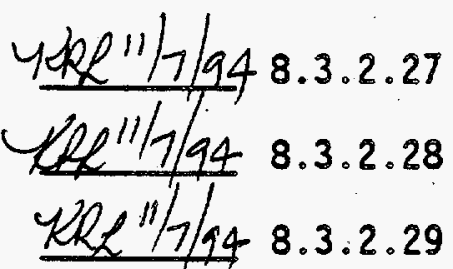

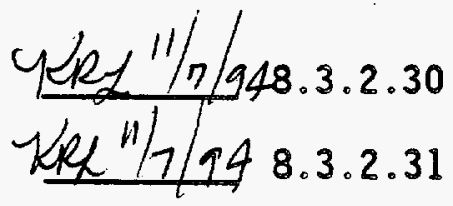

Control Trailer.

Turn "SYSTEM POWER" keyswitch located on the HPSS control panel to the "ON" position. Verify the red "SYSTEM POWER ON" indicator light is illuminated and that the green "SYSTEM POWER OFF" light is not illuminated.

Visually verify that the HPSS control panel meters have power in the FR Control Trailer.

Push "LAMP TEST" button and verify all indicator 1 amps become illuminated on the HPSS control panel in the FR Control Trailer.

Verify the green pilot lamp labeled "CONTINUITY GOOD" under "SYSTEM CONTINUITY" is lit and the red pilot lamp labeled "CONTINUITY LOST" is not lit. Do not proceed until this step is verified unless directed by COG Engineer.

Zero the "FLOW TOTALIZER" meter on the HPSS control panel according to the manufacturers instructions in the FR Control Trailer.

Note: Unless otherwise noted, the following steps will all be performed at the HPSS Pump Trailer Control Panel.

Zero the "TOTAL FLOW" meter according to the manufacturers instructions on the HPSS Pump Trailer.

Place the "LOCAL/REMOTE SWITCH" in the "LOCAL" position.

Place the "MOTOR SPEED" switch in the "MINIMUM" position at the HPSS Pump Trailer.

Verify that water in the water truck is at least half full.

Open the feed water line valve on the water truck.

Bles air from lines to portable feed pump.

Start the portable feed pump located between the HPSS Pump Trailer and the water supply truck according to the manufacturers instructions provided by the test director.

Pull out the "STOP" button on the HPSS Pump Trailer.

Push the "PUMP CONTROL START" button at the HPSS pump trailer. Slowly increase the "MOTOR SPEED" switch to 
Kes $11 / 7 / 948.3 .2 .32$ YRR $11 / 7 / 948.3 .2 .33$ $\frac{4 L R L^{11 / 7 / 948.3 .2 .34}}{4 \text { LL }^{11 / 7 / 948.3 .2 .35}}$ Kkp "H/948.3.2.36 Nes $11 / 948.3 .2 .37$ $4 R_{2} 1 / 7 / 948.3 .2 .38$ KR, $11 / \log 8.3 .2 .39$ 1/R2"1/1948.3.2.40 $4211 / 7 / 948.3 .2 .41$ Yel11/26y 8.3.2.42 YRL"1/7/948.3.2.43

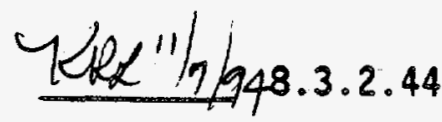

obtain discharge pressure of $3000+1-100$ psi or at a discharge pressure directed by the Test Director. Verify the HPSS pump begins operating.

Push the "PUMP CONTROL STOP" button at the HPSS Pump Trailer. Verify the HPSS pump operation is stopped.

Place the "MOTOR SPEED" switch in the "MINIMUM" position at the HPSS Pump Trailer.

Pull out the "PUMP CONTROL STOP' button.

Place the "LOCAL/REMOTE SWITCH" in the remote position.

NoTE: Unless otherwise noted, the following steps will be performed at the HPSS Control Panel located in the FR Control Trailer.

Put the "PUMP CONTROL MOTOR SPEED" in the minimum position in the FR Control Trailer.

Push the "PUMP CONTROL PUMP MOTOR START" button in the FR Control Trailer. Increase the "PUMP CONTROL MOTOR SPEED" to obtain discharge pressure of $1000+/-100 \mathrm{psi}$. Verify the HPSS pump begins operation.

Push the "PUMP CONTROL EMERGENCY STOP" button in the FR Control Trailer. Verify the HPSS pump operation is stopped.

Put the "PUMP CONTROL MOTOR SPEED" in the minimum position in the FR Control Trailer.

Push the "PUMP CONTROL PUMP MOTOR START" button in the FR Control Trailer. Increase the "PUMP CONTROL MOTOR SPEED" to obtain discharge pressure of $1000+1-100 \mathrm{psi}$. Verify the HPSS pump begins operation.

Push the "PUMP CONTROL STOP" button located at the HPSS Pump Trailer. Verify the HPSS Pump operation is stopped.

Fush the "PUMP CONTROL STOP" button in the FR Control Trailer.

Put the "PUMP CONTROL MOTOR SPEED" at the minimum setting in the FR Control Trailer and pull out the "PUMP CONTROL STOP" button located on the HPSS Pump Trailer.

Push the "PUMP CONTROL PUMP MOTOR START" button in the FR Control Trailer. Increase the "PUMP CONTROL MOTOR SPEED" 
to obtain discharge pressure of $3000+/-100$ psi or at a discharge pressure directed by the Test Director. Verify the HPSS pump begins operation.

Verify there are no visible leaks in the HPSS or record location of leaks and/or repair leakage and then record the following. Local readings are taken at the HPSS Pump trailer control pane]: Remote readings are taken at the HPSS control panel in the FR Control Trailer. "Total Flow" and "Flow Totalizer" readings are to be taken simultaneously. Verify the "Discharge Temperature" is $150^{\circ} \mathrm{F}+10^{\circ} \mathrm{F} /-30^{\circ} \mathrm{F}$ and that local/remote readings are consistent.

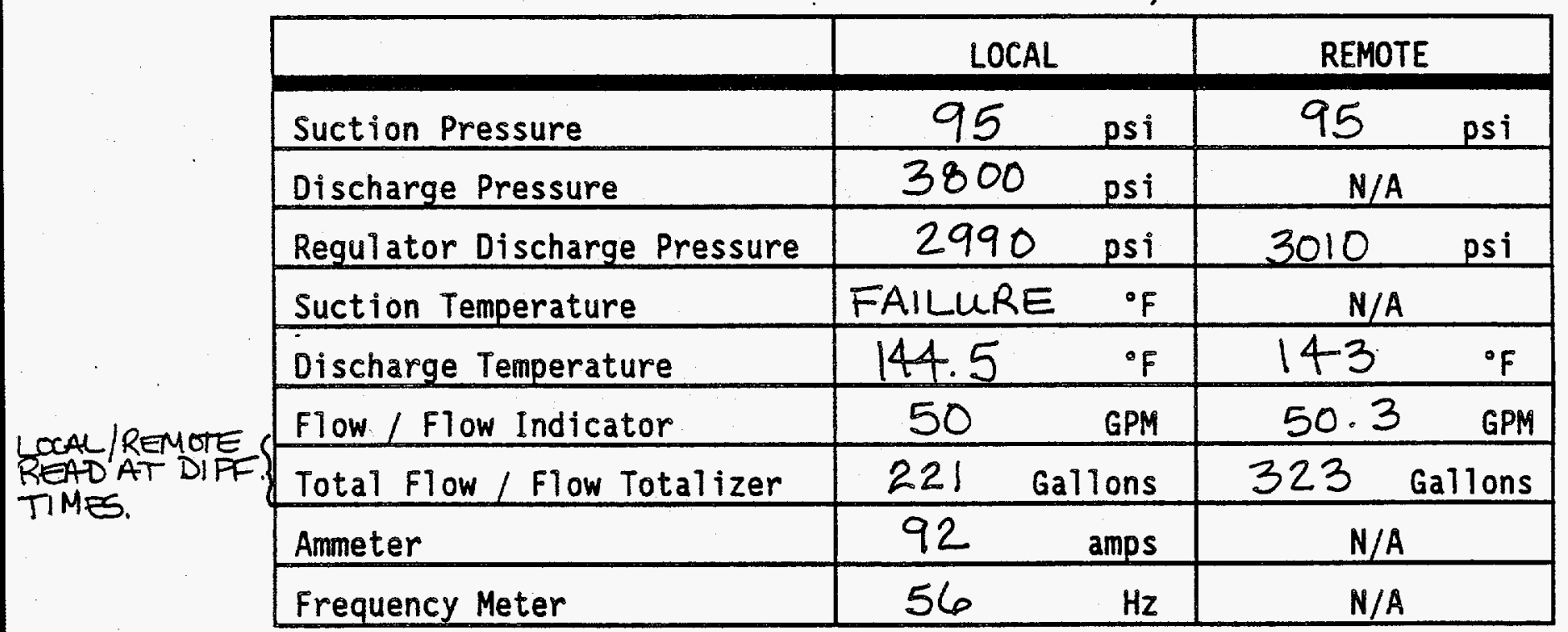

KR $11 / 7 / 948.3 .2 .46$ SEEECEPTON \#1

YRe $11 / 7 / 948.3 .2 .47$

KRL"1/994 8.3.2.48

YRe $1117 / 94$
Record and verify that the test pit vacuum is between 0.25 and 2 inches of water.

Pit Vacuum: 3.611

Record and verify that the wind velocity is $10 \mathrm{mph}$ or lins Velocity: $2-3$

Attach the crane hook to the eyebolt of the FR bag. Reset the crane total height meter to zero and then raise the crane hook at a constant rate provided by the Test Director.

Start recording on all three VCR's. 

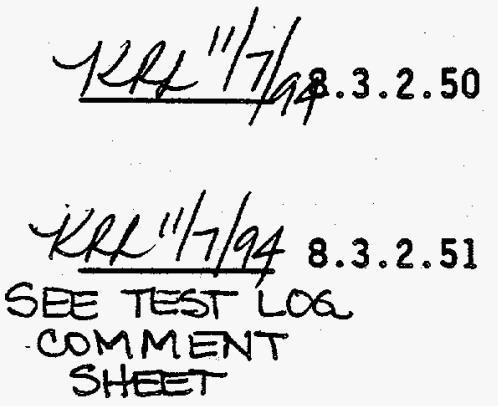

Keg $11 / 7 / 948.3 .2 .52$

YRe $11 / 7 / 948.3 .2 .53$

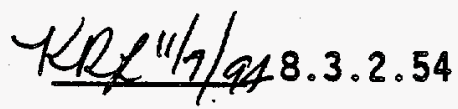

Observe the bag rings coming off of the stanchions. Verify there is no binding and that the rings are not separated from the bag.

Have crane stop pulling at about $20 \mathrm{ft}$ and lower equipment back down about $8 \mathrm{ft}$. Lowering the bag $8 \mathrm{ft}$ will simulate rewashing a section of the pump. Raise the bag $8 \mathrm{ft}$. After raising the bag the bag should not have overlapped on itself. Performing the next step is at the discretion of the Test. Director. Lower the equipment 10 -15 ft using the emergency ring replacing rod. Verify emergency rod with a hook can help in putting the rings back on the guide poles. Note: When the emergency ring replacing rod is used, the access window needs to be removed causing minimal negative pressure in the bag to facilitate ring replacement.

Start raising the bag until the closure indexing lines are in-line (Indexing lines are the lines marked on the stanchions and the first horizontal line on the bag). STOP raising the bag when the indexing lines are in alignment.

Record the crane hook elevation $46.9 \mathrm{ft}$.

STowly reduce pressure on the HPSS pump by turning the "PUMP CONTROL MOTOR SPEED" to the minimum setting in the FR Control Trailer and press the stop button.

Stop the portable feed pump and turn off the feed line valve on the water truck.

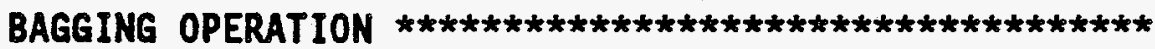

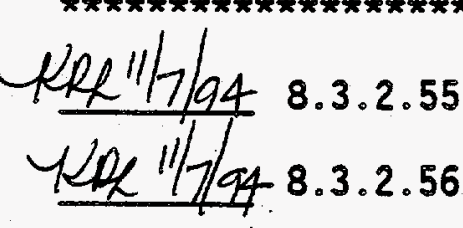

Kel"1/948.3.2.57
TUrn "HYORAULIC PWR UNIT" switch to the "ON" position.

At the FR control panel, turn and HOLD the "WINCH MOTORS" switch in the "ON" position for 30 to 45 seconds after the cables have stopped (visually determined by camera) and verify wire rope tightens around the bag forming seals both above and below the cutting blade and the bag tie wraps break without tearing the bag. Verify amber light on switch is lit. Verify and record "WINCH MOTORs" "HYDRAULIC PRESSURE" reach $1250 \pm 200$ psig from the control panel meter and local gauge on the receiver. Control Pane1: 1190 psig Local Gauge: 1300 psig

Release the "WINCH MOTORS" switch letting it spring return to the "OFF" position. Verify amber light in the switch is not 1it. Verify and record "WINCH MOTORS" "HYDRAULIC PRESSURE" reach $0 \pm 100$ psig from the local 
Reference-

gauges on the receiver.

Local Gauge: 0 psig

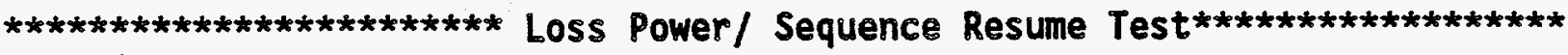

YRR $11 / 7 / 948.3 .2 .58$

Yele $11 / 7 / 948.3 .2 .59$

Kef $11 / 7$ /94 8.3 .2 .60

YRR"17/g4 8.3 .2 .62

KR2"1/7/948.3.2.63

4RE"h/94 8.3.2.64

YRe "1/7/94 8.3.2.61

Turn the "SYSTEM CONTROL POWER " key switch to the "OFF" position.

Wait 5 to 10 seconds, then turn the "SYSTEM CONTROL POWER" key switch to the "ON" position, press and release the "RESET" button.

Verify the sequence continues by "HYDRAULIC POWER" light switch illuminated, hydraulic pump is running and by performing the next step which is crimping the cable. If the next step cannot be performed, then stop test and contact COG engineer or Test Director.

At the FR control panel in the trailer, turn the "UPPER CABLE CLAMP" switch to "CRIMP" position and hold until pressure on the control panel meter "HYDRAULIC PRESSURE" reaches $3000 \pm 300$ psig. Verify amber light on switch is lit. Record "UPPER CABLE CLAMP" "HYORAULIC PRESSURE" from the control panel meter and local gauges on the receiver.

Control Panel: 3326 psig Local Gauge: 3000 psig

Return "UPPER CABLE CLAMP" switch to the "OFF" position. Verify amber light on switch is not lit. Verify and record "UPPER CABLE CLAMP". "HYDRAULIC PRESSURE" returned to $0 \pm 100$ psig from the local gauge on the receiver. Local Gauge: $O$ psig

Turn the "UPPER CABLE CLAMP" switch to "OPEN" position and hold until pressure reading on the control panel meter "UPPER CABLE CLAMP HYDRAULIC PRESSURE" reaches at least $500 \pm 200$ psig. Verify amber light on switch is lit. Record "UPPER CABLE CLAMP HYDRAULIC PRESSURE" from the control panel meter and local gauges on the receiver. Control Panel: 3000 psig Local Gauge: 3000 psig

Return "UPPER CABLE CLAMP" switch to the "OFF" position. Verify amber light on switch is not lit. Verify and record "UPPER CABLE CLAMP" "HYDRAULIC PRESSURE". returned to $0 \pm 100$ psig from the local gauges on the receiver. Local Gauge: 0 psig

KRL"1/7/94 8.3.2.65 At the FR control panel in the trailer, turn the "LOWER 
YRe "Hig4 8.3.2.66

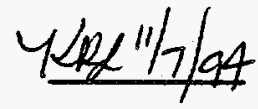

8.3 .2 .67

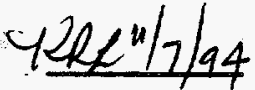

8.3 .2 .68

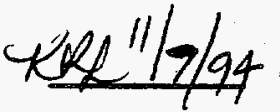

8.3 .2 .69

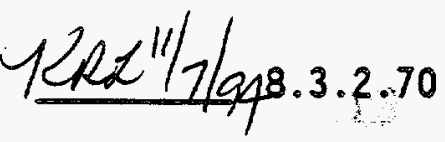

CABLE CLAMP" switch to "CRIMP" position and hold until pressure on the control panel meter "LOWER CABLE CLAMP HYDRAULIC PRESSURE" reaches $3000 \pm 300$ psig. Verify amber light on switch is 1 it. Record "LOWER CABLE CLAMP HYDRAULIC PRESSURE" from the control panel meter and local gauges on the receiver.

Control Panel: 2972 psig Local Gauge: 3000 psig

Return "LOWER CABLE CLAMP" switch to the "OFF" position. Verify amber light on switch is not lit. Verify and record "LOWER CABLE CLAMP" "HYDRAULIC PRESSURE" returned to $0 \pm 100$ psig from the local gauges on the receiver. Local Gauge: psig

Turn the "LOWER CABLE CLAMP" switch to "OPEN" position and hold until pressure on the control panel meter "LOWER CABLE CLAMP HYDRAULIC PRESSURE" reaches at least $500 \pm$ 200 psig. Verify amber light on switch is lit. Record "LOWER CABLE CLAMP HYDRAULIC PRESSURE" from the control panel meter and local gauges on the receiver. Control Panel: 2975 psig Local Gauge: 3000 psig

Return "LOWER CABLE CLAMP" switch to the "OFF" position. Verify amber light on switch is not lit. Verify and record "LOWER CABLE CLAMP HYDRAULIC PRESSURE" returned to $0 \pm 100$ psig from the local gauges on the receiver. Local Gauge: 0 psig

At the FR control panel in the trailer, turn the "BAG CUTTER" switch to the "CLOSE" position and hold until pressure on the control panel meter "BAG CUTTER HYDRAULIC PRESSURE" reaches at least $1000 . \pm 300$ psig, then return switch to the "OFF" position. Verify that the "BAG CUTTER OPENING" amber light is only lit while performing operation. Record final "BAG CUTTER HYDRAULIC PRESSURE" from the control panel meter and local gauges on the receiver. Also visually verify blades at the FR fully closed and the bag is cut.

Control Panel: 978 psig Local Gauge: 1000 psig

Turn the "BAG CUTTER" switch to the "OPEN" position and hold until pressure on the control panel meter "BAG CUTTER HYDRAULIC PRESSURE" reaches at least $500 \pm 100$ psig or until blades fully open, then return switch to the "OFF" position. Verify that the "BAG CUTTER/CLOSING" amber light is only lit while performing operation. Record final "BAG CUTTER HYDRAULIC PRESSURE" from the control panel meter and local gauges on the recejver. Control Panel: 1032 psig Local Gauge: 1100 psig 
CAUTION: In the following step do not hold the cable cutter switch in the "ON" position after the cable has been cut, this will damage the cable cutter.

At the FR control panel in the trailer, turn the "CABLE CUTTER UPPER" switch to the "ON" position and hold for 5 sec. or until the cable has been cut, then release the switch to spring return to the "OFF" position. Verify amber light on switch is only lit when switch is in the "ON" position. Visualiy verify that upper cable has been fully cut and that the clamp has held. (Field verification may also be used.)

CAUTION: In the following step do not hold the cable cutter switch in the "ON* position after the cable has been cut, this will damage the cable cutter.

At the FR control panel, turn the "CABLE CUTTER LOWER" switch to the "ON" position and hold for $5 \mathrm{sec}$. or until the cable has been cut, then release the switch to spring return to the "OFF" position. Verify amber light on switch is only lit when switch is in the "ON" position. Visualiy verify that lower cable has been fully cut and that the clamp has held. (Field verification may be used.) Verify the FR bag is fully cut.

Verify cable is tight around both ends of the bag and has not slipped off.

\subsubsection{Secondary Bagger Operations}

The sealed end of the primary bag is placed in the Secondary bagger machine. A second bag is applied over the lower portion of the Primary bag to provide a secondary "back-up" barrier. The secondary bag is intended to contain contamination on or between the upper cable seal and the bottom of the primary bag.

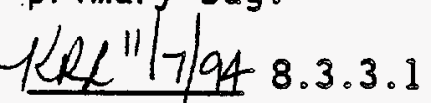

YRL $11 / 7 / 948.3 .3 .2$ SEE EXCEPTION \#2
Using the crane move the bagged equipment over to the secondary bagging station and pizce primary bag in secondary bag approximately 2 to 3 feet. Stop so that the cable on the Secondary Containment Assembly is between the rings of the bag.

At the FR control panel, turn and HOLD the "WINCH MOTORS" switch in the "ON" position for 30 to 45 seconds after the cables have stopped (visually determined by camera) and verify wire rope tightens around the bag forming seals both above and below the cutting blade and the bag 
KkR $117 / 948.3 .3 .3$
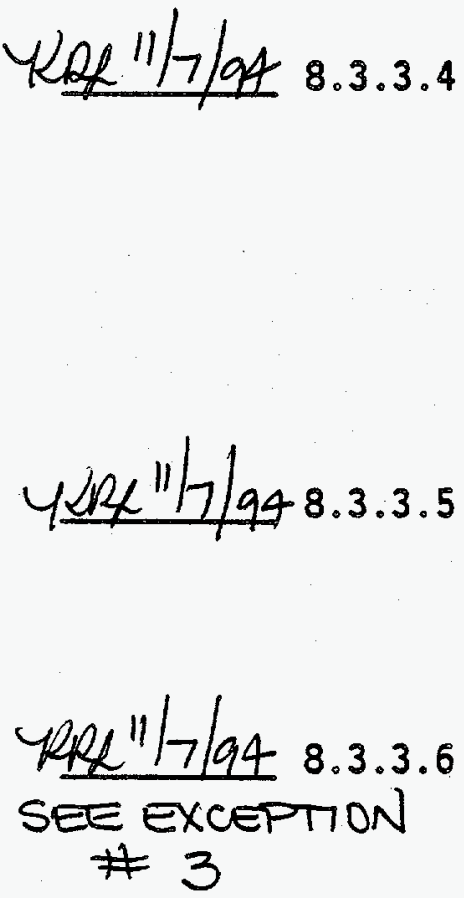

YRR"IJ/94 8.3.3.7

YRL $11 / 7 / 948.3 .3 .8$ tie wraps break without tearing the bag. Verify amber light on switch is lit. Verify and record "WINCH MOTORS" "HYDRAULIC PRESSURE" reach $1250 \pm 200 \mathrm{psig}$ from the control panel meter and local gauge on the receiver. Control Panel: 960 psig Local Gauge: 1100 psig

Return "WINCH MOTOR" switch to the "OFF" position. Verify amber light in the switch is not lit. Verify and record "WINCH MOTORS HYDRAULIC PRESSURE" reach $0 \pm 100$ psig from the local gauges on the secondary bagger. Local Gauge: Dsig

At the FR control panel under "SECONDARY CONTROL SYSTEM" in the trailer, turn the "CABLE CLAMP" switch to "CRIMP" position and hold until pressure on the control panel meter "CABLE CLAMP HYDRAULIC PRESSURE" reaches $3000 \pm 300$ psig. Verify amber light in the switch is 1 it when holding. Record "CABLE CLAMP HYORAULIC PRESSURE" from the control panel meter and local gauges on the secondary

Control Pane1: 2883 psig Local Gauge: 3000 psig

Return "CABLE CLAMP" switch to the "OFF" position. Verify amber light in the switch is not lit. Verify and record "CABLE CLAMP HYDRAULIC PRESSURE" returned to $0 \pm$ 100 psig from the local gauges on the secondary bagger. Local Gauge: $O$ psig

Turn the "CABLE CLAMP" switch to "OPEN" position and hold until pressure on the control panel meter "CABLE CLAMP HYDRAULIC PRESSURE" reaches $500 \pm 200$ psig. Verify amber light in the switch is lit when holding. Record "CABLE CLAMP HYDRAULIC PRESSURE" from the control panel meter and local gauges on the secondary bagger.

Control Panel: 1232 psig Local Gauge: 900 psig

Return "CABLE CLAMP" switch to the "OFF" position. Verify amber light in the switch is not 1it. Verify and record "CABLE CLAMP HYDRAULIC PRESSURE" returned to $0 \pm$ 100 psig from the local gauges on the secondary bagger. Local Gauge: psig

CAUTION: In the following step do not hold the cable cutter switch in the "ON" position after the cable has been cut, this will damage the cable cutter.

On the FR control panel under "SECONDARY CONTROL SYSTEM" turn the "CABLE CUTTER" switch to the "ON" position and 
hold for $5 \mathrm{sec}$. or until the cable has been cut, then release the switch to spring return to the "OFF" position. Verify amber light on switch is only lit when switch is in the "ON" position. Visually verify that cable has been fully cut and that the clamp has held. (Field verification may also be used.)

Kef "II Ta4 8.3.3.9

Lower the encapsulated simulated pump to the ground. Block as required to prevent the pump from moving. Remove the crane lifting hook from the bag eye.

Stop recording on the VCR's.

Turn the "HYDRAULIC PWR UNIT" switch to the "OFF" position. Turn the "START SEQUENCE" switch to the "OFF" position. Turn the "SYSTEM CONTROL POWER" switch to the "OFF" position.

\subsubsection{Manual Control}

The use of MANUAL CONTROL requires the use of a key switch. When the MANUAL CONTROL key switch is placed in the ON position, the amber light by the MANUAL CONTROL key switch lights and the controller performs any requested operation without regard to the interlocks or sequence.

NOTE: Operation of the MANUAL CONTROL key switch will disrupt the control sequence. Once the MANUAL CONTROL key switch is used to perform an out of sequence action, the remaining operations must be completed under manual control.

\section{Initial/Date}

uRe"l/7/a48.3.4.1

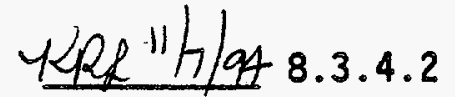

YKL $11 / 7 / 94$

8.3 .4 .3

Ykf"Hlat8.3.4.4
Verify there is power to the FR control rack. This is denoted by a lit green lamp labeled "POWER OFF" under "SYSTEM CONTROL POWER".

Turn FR control system power ON by rotating "SYSTEM CONTROL POWER" control key to the ON position. A red panel light labeled "POWER ON" under "SYSTEM CONTROL POWER" indicates tt.s power is applied to the Control System when lit.

Turn the "START SEQUENCE" key switch to the "ON" pOsition and verify the green pilot lamp labeled "READY" is lit.

Turn the "MANUAL CONTROL KEY" to the on position. 
Turn "HYDRAULIC P.WR UNIT" switch to the "ON" position and verify green lamp in the switch is lit and the Hydraulic power unit motor is operating by visual inspection.

NOTE: The following manual steps are to be field verified since this is only a verification that a function operates.

YRe "IJg48.3.4.6

On the FR control panel in the trailer, turn and HOLD the "WINCH MOTORS" switch to the "ON" position and verify motors are operating. Switch to the "OFF" position and verify the motors stop running.

TRR 117/g4 8.3.4.7

Wef IIt 7 a4 8.3 .4 .8

Yef $11 / 7 / 348.3 .4 .9$

MRR "1/7948.3.4.10

$K R / 117948.3 .4 .11$

YLRR 11/7948.3.4.12

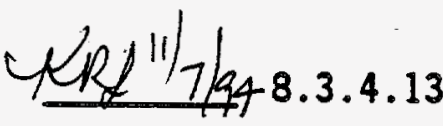

On the FR control panel in the trailer under the "SECONDARY / CONTROL / SYSTEM", turn and HOLD the "WINCH MOTOR" switch to the "ON" pOsition and verify motor is operating on the secondary bag receiver. Switch to the "OFF" position and verify it stops running.

On the FR control panel in the trailer, turn the "UPPER / CABLE CLAMP" switch to "CRIMP" position and verify panel amber light on switch is lit and in the field, movement of crimper. DO NOT HOLD FOR A LONG PERIOD OF TIME, ONLY VERIFY MOVEMENT OF ACTUATOR.

Release the "UPPER CABLE CLAMP" switch so it spring returns to the "OFF" position. Verify amber light in the switch is not lit and in the field, crimper does not move.

Turn the "UPPER CABLE CLAMP" switch to "OPEN" position and verify the amber light in the switch is lit and in the field, movement of crimper. DO NOT HOLD FOR A LONG PERIOD OF TIME, ONLY VERIFY MOVEMENT OF ACTUATOR.

Release the "UPPER CABLE CLAMP" switch to the "OFF" position. Verify the amber light in the switch is not lit and in the field, verify the crimper does not move.

On the FR control panel under "SECONDARY CONTROL SYSTEM" turn the "CABLE CLAMP" switch to "CRIMP" position and verify the amber light in the switch is lit and in the fieid verify movement of the crimper. DO NOT HOLD FOR A LONG PERIOD OF TIME, ONLY VERIFY MOVEMENT OF ACTUATOR.

Release the "CABLE CLAMP" switch to the "OFF" position. Verify the amber light in the switch is not lit and in the field verify the crimper does not move. 


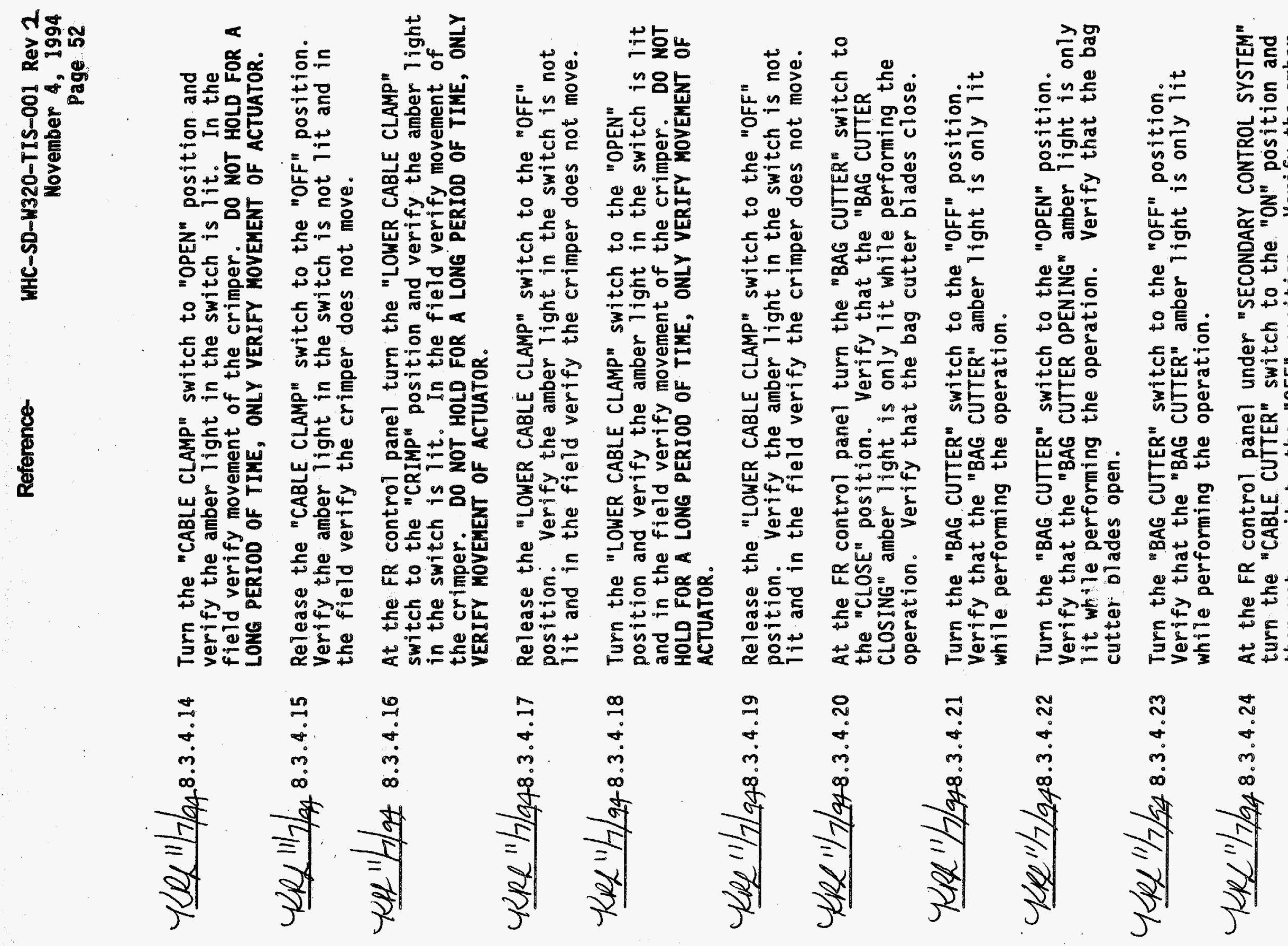


light in the switch is only lit when the switch is in the "ON" position. Verify that the cable cutter functions.

At the FR control panel turn the "CABLE CUTTER UPPER" switch to the "ON" position and then return it to the "OFF" position. Verify amber light in the switch is only lit when the switch is in the "ON" position. Verify thatthe cable cutter functions.

At the FR control panel turn the "CABLE CUTTER LOWER" switch to the "ON" position and then return it to the "OFF" position. Verify the amber light in the switch is only lit when the switch is in the "ON" position. Verify that the cable cutter functions.

\subsubsection{Master Reset}

The control system will initialize/clear all sequential flags etc. and return to the beginning of the operational sequence.

KRL"1/7/94 8.3.5.1

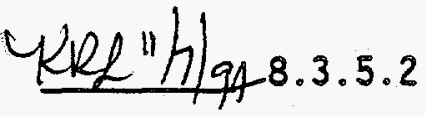

YRL"IJ948.3.5.3

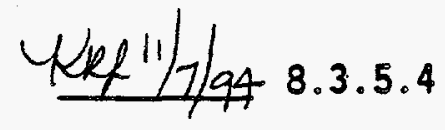

HRL" $11 \mathrm{hg} 48.3 .5 .5$
Verify the MANUAL CONTROL key switch is in the ON position.

Attach the PLC accessories needed to monitor the status of internal coils $300_{\text {HEX }}-307_{\text {HEX }}, 310_{\text {HEX }}-315_{\text {HEX }}$ and $317_{\text {HEX }}$.

Press the RESET button. Verify this turns off al1 internal coils (listed above) from on to off and returns the operational sequence to the beginning of the cycle/sequence. Release the RESET button.

Turn the MANUAL CONTROL POWER key switch to the OFF position and remove the key. Remove the PLC accessories.

Turn the following power switches to the OFF position.

- Hydraulic Power Unit

- Start Sequence

- Flexible Receiver System Control Power

- High Pressure Spray System Control Power

\subsection{REFERENCES}

\subsection{DRAWINGS}

For the 42": See H-2-79341 "TWRS Drawing Index 42" Tank 101-AZ Waste Retrieval System" for the list of drawings that apply.

For the $4^{n-6 n}$ : See H-2-79335 "TWRS Drawing Index 4"-6" Tank 101-AZ 
Waste Retrieval System" for the list of drawings that apply.

\subsection{VENDOR INFORMATION}

- Series One ( $\mathrm{tm}$ ) Junior Programmable Controller Users Manual by GE Fanuc Automation (part number GEK-90503A, March 1987)

- Operating Instructions - Panasonic, VHS, AG-1970P, Video Cassette Recorder

- Appendix E Model 2380-200 Camera Control Unit - COHU

\subsection{OTHER INFORMATION}

9.3.1 WHC-SD-W151-FDC-001, Rev. 2, "Functional Design Criteria, Project W151, 101-AZ Waste Retrieval System".

9.3.2 WHC-SD-W151-CDR-001, "Conceptual Design Report, Tank 101-AZ Waste Retrieval System, Project W151".

9.3.3 WHC-SD-W151-SDRD-001, "Supplemental Design Requirements Document, 241-AZ-101 Waste Retrieval System".

9.3.4 WHC-SD-W151-CSWD-001, "Design Description for the Flexible Receiver Controi System".

9.3.5 WHC-SD-W151-TRP-001, "Interim Development Test Report for Project W151 4/6 Inch Flexible Receiver and Thermocouple Tool".

9.3.6 WHC-SD-W320-FDC-001, Rev 2 "Functional Design Criteria for Tank 241-C-106 Waste Retrieval, Project W-320"

9.3.7 DOE-RL-92-36, "Hanford Site Hoisting and Rigging Manua1."

9.3.8 WHC-SD-W151-CSCM-001, Rev O "Software Configuration Management Plan for the Flexible Receiver Control System"

9.3.9 WHC-SD-W151-ATR-001, "Project W-151 Flexible Receiver Radiation Detector System Acceptance Test Report".

\subsection{DATA SHEFTS}

\subsection{TEST EXCEPTION SHEET}

Exception Data Sheets are used to document exceptions to the test procedure and results. A description of the exception and the disposition are provided on the exception sheet. Typical dispositions are:

1. Test approved with exception (i.e., rerun of the acceptance test unnecessary). 
2. Acceptance Test Procedure step(s) affected to be repeated after the discrepancy has been corrected.

The following is the Test Exception Sheet that will be used. Additional copies will be made as needed. 
Reference-

\subsection{TEST LOG SHEET}

Test Log Sheets will be used to document test start and stop times and to document any notes concerning the execution of the qualification Test Procedure.

The following is the test log sheet that will be used. Additional copies will be made as needed. 
TEST LOG

DATE/TIME

COMHENTS

\begin{tabular}{l|l}
$11 / 7194$ & 8.3 .2 .51 - EQUIPMENT WAS NOT LOWERED \\
09 & 10-15 FEET USING THE EMERGENGI RING \\
\cline { 2 - 3 } & REPLACING ROD.
\end{tabular}

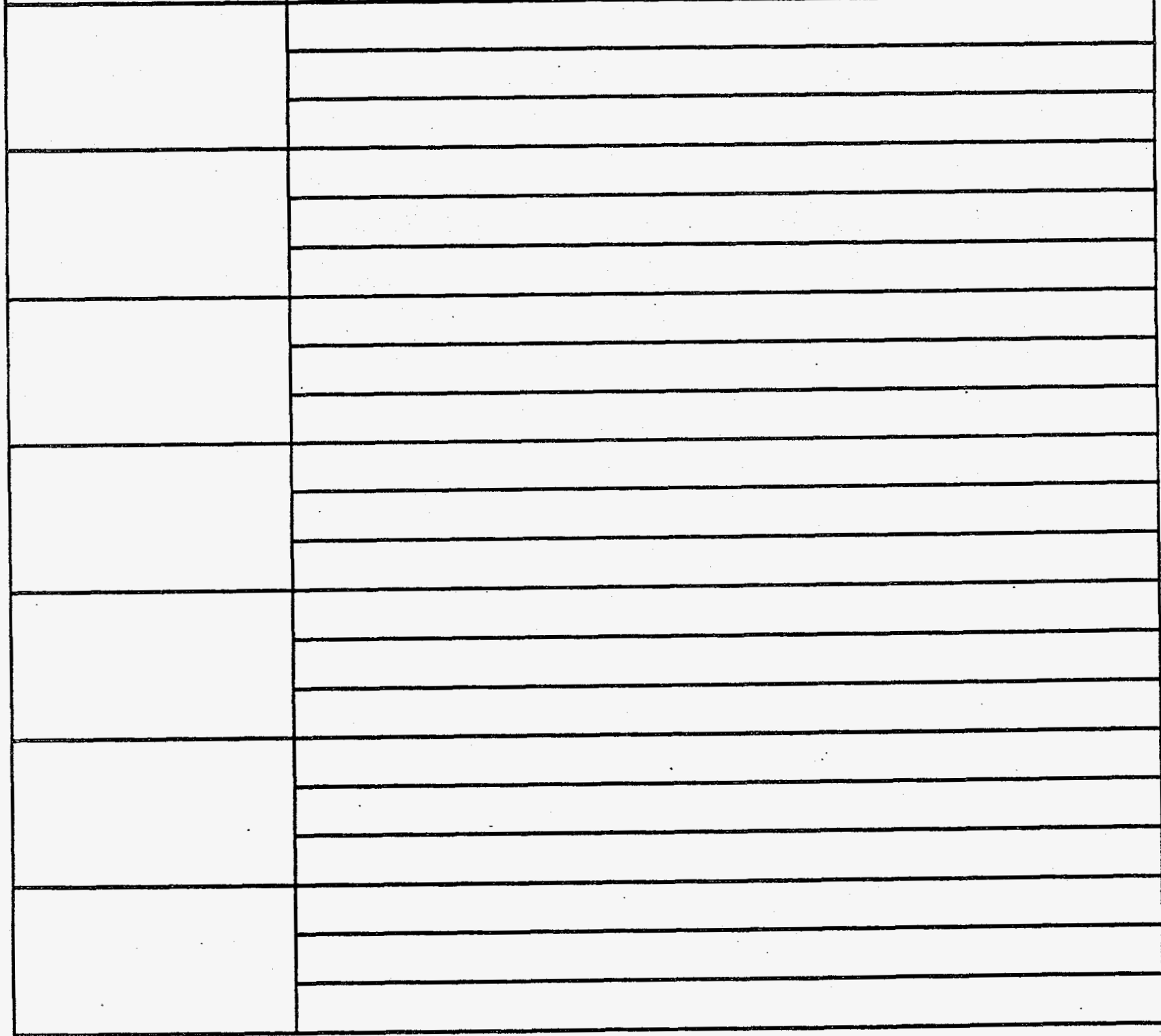


Reference-

$$
\begin{gathered}
\text { WHC-SD-W320-TIS-001 Rev } \not 2-\alpha e z \\
\text { November } \not, 41994 \text { are } \\
\text { Page } 56
\end{gathered}
$$

TEST EXCEPTIONS

EXCEPTION NO:

PROCEDURE STEP NO: 8.3 .2 .46

DATE: $11 / 7 / 94$

DESCRIPTION:

PIT VACUUM WAS 3.6", OVER THE $0.25^{\prime \prime}$ TO 2" REQUIREMENT DUE TO DESIGN OF HVAC SYSTEM. REGULATION OF PIT VACUUM TO A LOWER READING WAS NOT POSSIBLE. ALSO, READING OF PIT VACUUM SHOW U BE TAKEN AT THE SAME TIME TH HAT STEP 8.3 .2 .5115 .

RESOLUTION:

ACCEPT AS IS

APPROVALS:
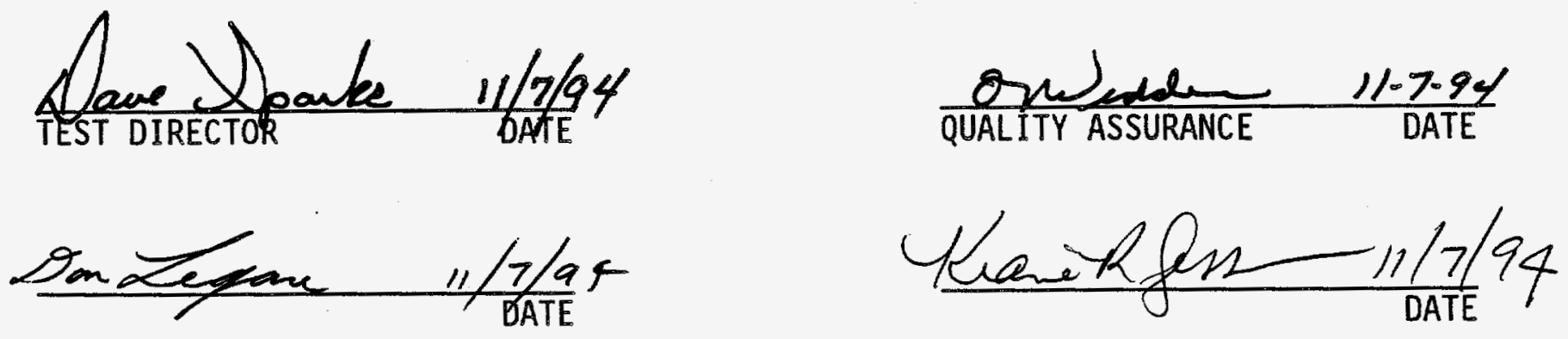

A.66 
Reference-

WHC-SD-W320-TIS-001 Rev 012 ax

November 341994
Page 56

TEST EXCEPTIONS

EXCEPTION NO: 2

PROCEDURE STEP NO: 8.3 .3

DATE: $11 / 7 / 94$

DESCRIPTION:

THE manUAL CONTROL KEY HAD TO BE TURNED tO THE ON POSITION BETWEEN STEPS 8.3 .3 .1 AND 8.3 .3 .2 DUE TO THE Fact THAT THE "CABLE cutTer LOWER" WAS NOT ACTIUATED LONG ENOUGH IN STEP 8.3.2.72 TO TRIP OUT THE RELAYS IN THE TLC.

RESOLUTION:

ACCEPT AS IS. TIMING CONTROL LOGIC WILL BE ADJUSTED, BY WHO.

APPROVALS:
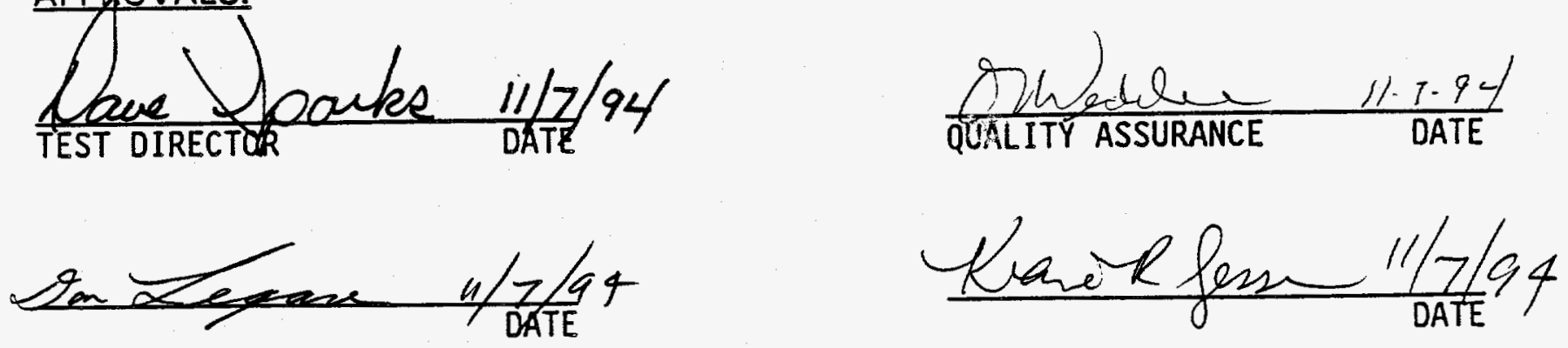

A-67 


\section{TEST EXCEPTIONS}

EXCEPTION N0: 3

PROCEDURE STEP NO: 8.3 .3 .6

DATE: $11 / 7 / 94$

DESCRIPTION:

THE STEP READS TURN THE "CABLE CLAMP"....

$\therefore$. REACHES $500 \pm 200$ PSIG. THE STEP SHOULD

READ "AT LEAST" PRIOR TO $500 \pm 200$ PSIG.

RESOLUTION:

ACCEPT AS IS. COG. ENGR, TO REV. PROCEDURE.

APPROVALS:

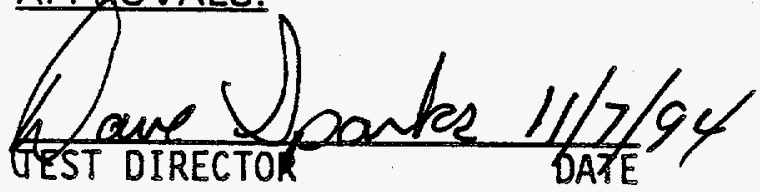

$\frac{\text { Dudelee }}{\text { QUALITY ASSURANCE }} \frac{11.7-94}{\text { DATE }}$

Senerex

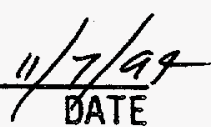

Herérfers $11 / 9194$ 